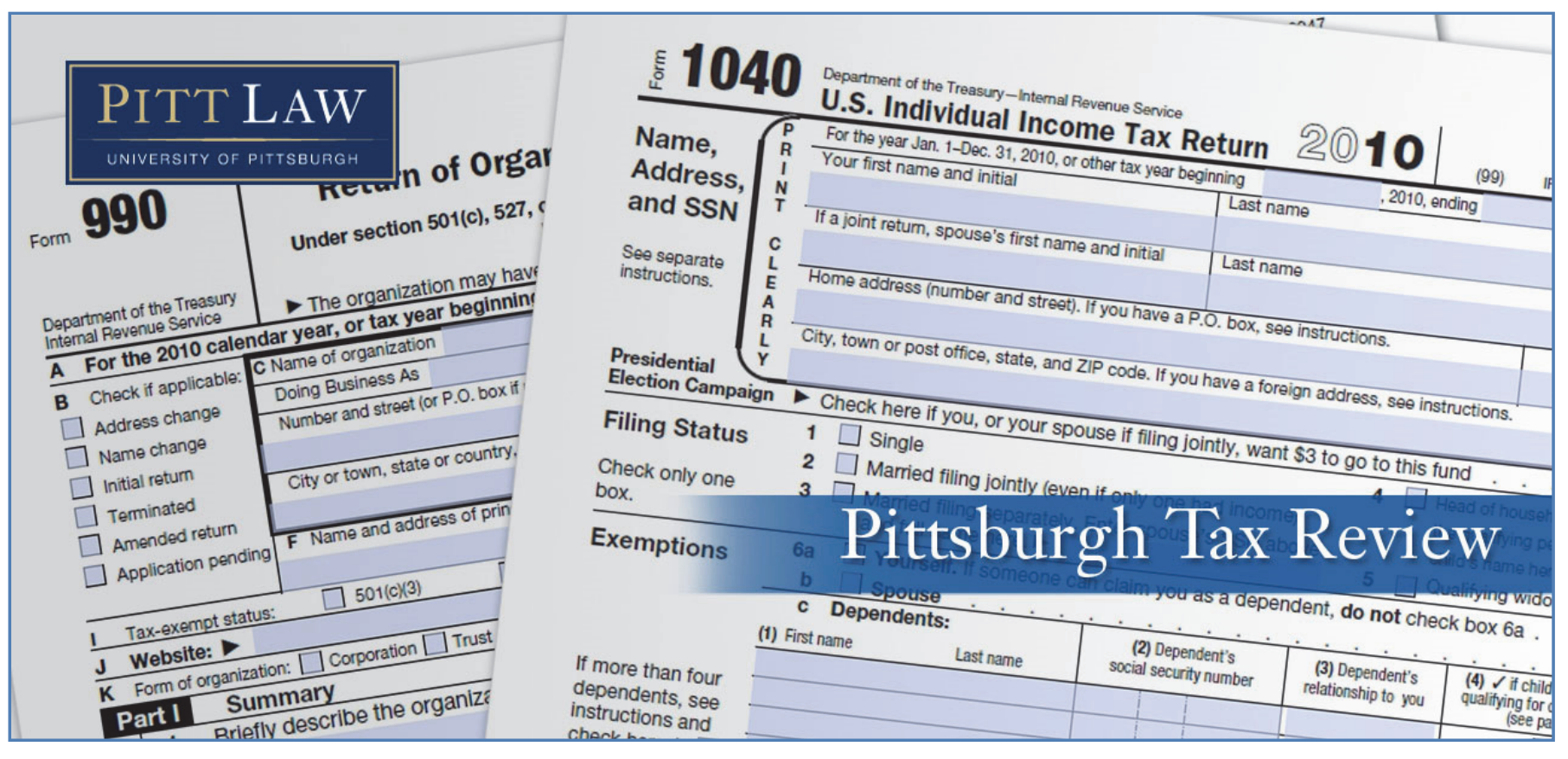

Volume 15 (2017) | ISSN 1932-1821 (print) 1932-1996 (online)

DOI 10.5195/taxreview.2017.68 | http://taxreview.law.pitt.edu

\title{
LEARNING THE HARD WAY: DECIPHERING THE CORRECT TAX TREATMENT OF GRADUATE EDUCATION BENEFITS FOR UNIVERSITY FACULTY
}

Steven Z. Hodaszy \& Gregory J. Krivacek

\section{(cc) EY-NO-ND}

This work is licensed under a Creative Commons Attribution-Noncommercial-No Derivative Works 3.0 United States License.

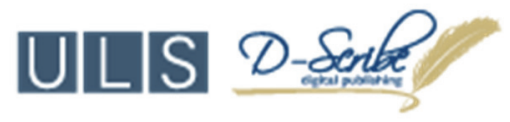

This journal is published by the University Library System of the University of Pittsburgh as part of its D-Scribe Digital Publishing Program, and is cosponsored by the University of Pittsburgh Press. 


\title{
LEARNING THE HARD WAY: DECIPHERING THE CORRECT TAX TREATMENT OF GRADUATE EDUCATION BENEFITS FOR UNIVERSITY FACULTY
}

\author{
Steven Z. Hodaszy ${ }^{*}$ \& Gregory J. Krivacek ${ }^{* *}$
}

\section{INTRODUCTION}

The life of the mind may not be a sure path to riches, but the ivory tower is not entirely without its material rewards either. One particularly attractive perquisite of being on a university faculty is the opportunity that many faculty members get to earn advanced degrees from their home institutions either for free or at greatly reduced cost. This article examines the appropriate federal income tax treatment of this valuable benefit.

There are numerous circumstances in which a professor might pursue a graduate degree from the university at which she teaches, and in which the university might provide the degree for little or no tuition. On occasion, for example, a school might hire an instructor with a master's degree for a tenure-track position in a field in which a $\mathrm{PhD}$ is the terminal degree, on the contingency that she complete her doctorate at the institution by the date of the tenure decision. Similarly, a university might encourage a tenured professor who was hired years ago, when a master's degree was the minimum requirement for academicians in her field, to earn a $\mathrm{PhD}$ at the school in order to conform to current standards for faculty credentials or to meet institutional accreditation requirements. ${ }^{1}$ In other cases, a professor who already has the

* Assistant Professor of Taxation, Robert Morris University School of Business, Moon Township, PA. A.B., Amherst College, 1988; J.D., New York University School of Law, 1991; LL.M. (taxation), New York University School of Law, 2010.

** Assistant Professor of Accounting, Robert Morris University School of Business, Moon Township, PA. B.S.B.A, Robert Morris University, 1980; M.S. (Financial Information), Carnegie Mellon University, 1994; Ph.D., Robert Morris University, 2016.

${ }^{1}$ For example, a business school that wishes to gain or maintain accreditation by the Association to Advance Collegiate Schools of Business (AACSB) may try to persuade its tenured professors who do not already possess a $\mathrm{PhD}$ to earn a doctorate, in order to ensure that the school's faculty includes the AACSB-mandated percentage of "scholarly academics." See Ass'N TO ADVANCE COLLEGIATE SCH. OF Bus., EligIBILITY PROCEDURES AND ACCREDITATION STANDARDS FOR BUSINESS ACCREDITATION $43-$ 46 (2017), http://www.aacsb.edu/-/media/aacsb/docs/accreditation/standards/business-accreditation2017-update. ashx?la=en (outlining AACSB Business Accreditation Standard 15's requirement that at least $40 \%$ of an accredited business school's faculty normally be comprised of "scholarly academics" and 
requisite terminal degree in her discipline may wish to earn an additional advanced degree at her university to expand her academic horizons (which, in turn, will enhance her teaching and research at the school). For instance, a business school professor with a doctorate in marketing might wish to pursue a second $\mathrm{PhD}$ in management. Perhaps a literature professor with a $\mathrm{PhD}$ in English may desire an additional master's degree in some particular subspecialty, such as seventeenth-century Irish poetry. Or, a government professor with a doctorate in political science might want to earn a JD from her university's law school to aid in her study and teaching of constitutional theory.

In each of these situations, the faculty member receives a significant economic benefit - the difference between the little or nothing that she actually pays for her degree and the tuition that the university ordinarily charges. Sometimes, a school will simply permit a faculty member to enroll in the requisite courses for free (or for a greatly reduced tuition). In other cases, the university will structure the benefit as an interest-free loan with a forgiveness provision. Either way, the professor is typically required to reimburse her university (i.e., to pay the full amount of the ordinary tuition for her coursework) if she departs the school's faculty within a certain period (say, within one to three years) following her receipt of the degree. ${ }^{2}$ Such requirement ensures that the university will receive the continued services of the faculty member whose increased training and credentials the school provided. This better enables the school to enhance the qualifications and

2017-update. ashx?la=en (outlining AACSB Business Accreditation Standard 15's requirement that at least $40 \%$ of an accredited business school's faculty normally be comprised of "scholarly academics" and noting that, to be a "scholarly academic," a faculty member must, inter alia, possess an appropriate terminal degree-which, in most disciplines, is a $\mathrm{PhD}$ ).

${ }^{2}$ In its most recent analysis of graduate tuition reductions for university employees, for example, the Internal Revenue Service (IRS) looked at a fact pattern in which a school permitted full-time employees (including, but not limited to, faculty) to take graduate-level courses without paying tuition. See I.R.S. Non-Docketed Serv. Adv. Review 2010-39-01F (July 27, 2010). In that case, the university required each "employee receiving graduate tuition waivers [to] complete an Employee Waiver Contract which stipulates that he or she will reimburse [the school] if the employee leaves [the school's] employment within one year of completion of the graduate coursework." Id. In addition, the authors are personally aware of faculty tuition-reduction benefits that are structured as loan contracts. Under the terms of the loan contracts with which the authors are familiar, the university advances the professor the funds for payment of the tuition, and the scheduled repayment date is a certain number of years-say, three years - after the professor earns her degree. Yet the contract also provides that the loan will be forgiven if the borrower-professor remains on the university's faculty at the end of the two- or three-year period following the award of the degree.

Pitt Tax Review | ISSN 1932-1821 (print) 1932-1996 (online)

DOI 10.5195/taxreview.2017.68 | http://taxreview.law.pitt.edu 
expertise of its faculty and improve the quality of the instruction that its students receive. At the same time, of course, the professor who gets the free (or discounted) degree receives a substantial investment in her professional development that will aid in the advancement of her career at the granting institution.

While the benefit to the faculty member is abundantly clear, the proper federal income tax treatment of the tuition reduction is far less so. In the absence of any applicable exclusion, the value of the education that a university provides to one of its professors - the amount of the tuition reduction - is includible in the professor's gross income as compensation for services. ${ }^{3}$ However, there are several exclusions from gross income that, at least on first impression, might apply to exempt the tuition reduction from taxation. The challenge in determining which of them actually $d o$ apply-in any particular case - is that the interrelationship among the exemption for "qualified tuition reductions" under $\S 117(\mathrm{~d}),{ }^{4}$ the exemption for employerprovided educational benefits under $\S 127,5$ and the exemptions for certain other employee fringe benefits under $\S 132^{6}$ is surprisingly complex. In the context of graduate education benefits to university faculty, the availability of some exemptions ${ }^{7}$ often hinges on the applicability (or inapplicability) of the others in ways that are notably difficult to decipher.

${ }^{3}$ I.R.C. $§ 61(a)(1)$ (providing that, unless elsewhere expressly excluded, all forms of compensation for services - including, inter alia, fringe benefits - are includible in a taxpayer's gross income); see also Joseph M. Dodge, Scholarships Under the Income Tax, 46 TAX LAW. 697, 700 (1993) (discussing how tuition reductions for employees of educational institutions may be characterized as compensation in the form of "fringe benefits").

${ }^{4}$ I.R.C. $\S 117$ (d) (providing for an exclusion from gross income of certain "qualified tuition reductions" granted by educational organizations to their employees).

${ }^{5} I d . \S 127$ (providing an exclusion from gross income of the value of certain educational assistance furnished by a taxpayer's employer, in an amount not to exceed $\$ 5,250$ in any calendar year).

${ }^{6} I d$. $\S 132(\mathrm{a})(1)-(3)$ (providing exclusions from gross income for certain categories of employee fringe benefits, including "no-additional-cost services," "qualified employee discounts," and "working condition fringes").

${ }^{7}$ One category of exclusions that cannot apply, even when a faculty tuition reduction is documented as a loan contract with a forgiveness provision, is the set of exclusions for certain types of discharge of indebtedness income. See generally id. § 108 (setting forth various exclusions from gross income of "income from discharge of indebtedness"). What is in substance an employee tuition reduction should be analyzed as fringe-benefit compensation, rather than as discharge of indebtedness income, even when the tuition reduction is structured as a loan contract with a forgiveness provision. This is because, in any such

Pitt Tax Review | ISSN 1932-1821 (print) 1932-1996 (online) DOI 10.5195/taxreview.2017.68 | http://taxreview.law.pitt.edu 
In the first instance, the perplexity of the rules affects universities that provide graduate tuition reductions to their faculty. Those universities must determine whether to include the amounts of such tuition reductions as reportable income on the faculty members' Forms $\mathrm{W}-2^{8}$ and whether to withhold and remit federal income tax, FICA taxes, and FUTA taxes on those amounts. ${ }^{9}$ And, apparently, many universities have difficulty in making such determinations. ${ }^{10}$ In 2013, the IRS completed a study of federal tax

case, the conditional discharge of the so-called indebtedness is contemplated under the terms of the original contract. "[W]hen the reduction in the amount to be paid by the debtor is pursuant to the original terms of the obligation, the amount of the reduction may constitute income to the debtor, but not cancellation of debt income." Martin J. McMahon, Jr. \& Daniel L. Simmons, A Field Guide to Cancellation of Debt Income, 63 TAX LAW. 415, 432 (2010) (discussing United States v. Centennial Sav. Bank FSB, 499 U.S. 573, 579 (1991)). As a result, the amount of the tuition reduction effected under a loan contract with a forgiveness provision does not constitute discharge of indebtedness income in the first place. See id. (noting how, in cases where the discharge of an obligation is pursuant to the original terms of the parties' agreement, "the debtor ... will not be permitted to take advantage of the provisions in $\S 108$, which apply only to cancellation of debt income," and discussing Centennial Sav. Bank, 499 U.S. at 583). Thus, for example, when included as part of a loan contract between a faculty member and her university, the faculty member's tuition reduction could not be treated as a purchase price adjustment under $\S 108(\mathrm{e})(5)$.

${ }^{8}$ Like other employers, a university must file an information return with respect to salaries or wages that it pays to an employee in the amount of $\$ 600$ or more during a given taxable year, and must provide a statement to such employee setting forth the aggregate payments to the employee required to be shown on such return. I.R.C. $§ 6041(a),(d)(1)$. However, a university is not "required to file Forms W-2, or any returns of information under section 6041," with respect to "tuition reimbursement and remission benefits paid" to its employees if those benefits do not constitute "wages" for the purpose of the foregoing rule because they are excludable from an employee's gross income. E.g., I.R.S. Priv. Ltr. Rul. 2015-16-030 (Jan. 9, 2015); I.R.S. Priv. Ltr. Rul. 2000-29-051 (Apr. 26, 2000).

${ }^{9}$ Like other employers, a university must withhold the appropriate amount of federal income tax from wages it pays to an employee, and the university is liable for the payment of such tax to the federal government. I.R.C. $\S \S 3402,3403$. Also, like other employers, a university must withhold from each employee's wages and remit to the federal government the Federal Insurance Contribution Act (FICA) taxes imposed on the employee, and the university must pay its own "matching" share of such FICA taxes. $I d$. $\S 3102,3111$. Similarly, like other employers, a university must pay Federal Unemployment Tax Act (FUTA) taxes on the wages it pays to its employees. Id. $\S 3301$. However, a university is not required to withhold or remit any federal income tax, FICA tax, or FUTA tax on the value of tuition reduction benefits to an employee if those benefits do not constitute "wages" for purposes of the foregoing rules because they are excludable from an employee's gross income. E.g., I.R.S. Priv. Ltr. Rul. 2015-16-030 (Jan. 9, 2015) (value of tuition reduction benefits to university employees do not constitute "wages" for purposes of $\S 3401$ (a) and are not subject to $\S \S 3402,3102$, or 3301 where such benefits are excludable under $\S 117$ (d)); I.R.S. Priv. Ltr. Rul. 2000-29-051 (Apr. 26, 2000) (same).

${ }^{10}$ See infra notes 299-300 and accompanying text (discussing differing policies that different universities have adopted regarding whether and when graduate tuition reductions to employees are excludable, and noting the underlying confusion evidenced by such differences in approach).

Pitt Tax Review | ISSN 1932-1821 (print) 1932-1996 (online)

DOI 10.5195/taxreview.2017.68 | http://taxreview.law.pitt.edu 
compliance among colleges and universities, ${ }^{11}$ and it found that all of the schools examined had underreported their employees' taxable wages and had underpaid their employment taxes. ${ }^{12}$ Among the specific reasons that the IRS identified for such noncompliance was the schools" "failure to include in income the value of certain graduate tuition waivers and reimbursements."13

Ultimately, of course, this perplexity has the greatest impact on the professors who receive tuition-free graduate degrees from their schools. Nobody wants to pay tax on income that is properly excludable; yet no one wants to incur penalties for underreporting income, either. Because the interplay among the relevant exclusion rules is rather convoluted, professors who receive tuition-free graduate degrees from their universities can easily become confused about how best to report the benefit on their federal income tax returns. ${ }^{14}$ As a result, some faculty members might be inclined to claim

${ }^{11}$ Internal REVEnUe SERV., IRS EXEMPT ORganizations: COlleges AND Universities COMPLIANCE PROJECT FinAL REPORT (2013), https://www.irs.gov/pub/irs-tege/CUCP_FinalRpt_ 050213.pdf.

${ }^{12} I d$. at 19. As part of the compliance study, the IRS performed employment tax examinations on eleven sample colleges and universities. Each exam resulted in adjustments to the universities' employment tax returns, relating to substantial increases in taxable employee wages, which in turn resulted in significant additions to the schools' employment taxes (and, also, related penalties). Id.

${ }^{13} I d$. at 20.

${ }^{14}$ Of course, when listing gross income on a federal income tax return, an employee must report the same amount of wage or salary income that is shown on the Form W-2 from her employer. However, if the employer incorrectly includes as "employee wages" on the Form W-2 an amount of income that is properly excludable, the employee can deduct such amount - as an above-the-line deduction in arriving at adjusted gross income-when preparing her return. I.R.S. Notice 89-33, 1989-1 C.B. 674. The IRS has issued an administrative notice specifically to instruct employees how to deduct employer-provided educational assistance benefits that are excludable, but that the employer incorrectly reported as wages on the employee's Form W-2. Id. In that notice, the IRS states, "If amounts that are properly excludable under section 117, section 127, or section 132 are erroneously included in the employee's gross income on Form W-2, the employee may deduct such amount in computing adjusted gross income using Form 2106 ...." Id. Specifically, the IRS instructs an employee in such situation to file a Form 2106 (Employee Business Expenses) with her Form 1040 and, on line 4 of the Form 2106, to list as a deductible expense the excludable income that was wrongly listed as wages on her Form W-2. See id. Actual employee business expenses reportable on Form 2106 are miscellaneous itemized deductions (the deductibility of which is suspended for taxable years beginning after 2017 and before 2026). See infra notes 158-59. However, the IRS notice makes clear that the deduction of the wrongly-reported wages will be an abovethe-line deduction in arriving at adjusted gross income. See id. The notice also states that any such properly excludable income "is not subject to Federal employment taxes, including income tax withholding, and employers should correct any underpayment or overpayment pursuant to the instructions provided in Circular E (Employer Tax Guide)." Id.

Pitt Tax Review | ISSN 1932-1821 (print) 1932-1996 (online) DOI 10.5195/taxreview.2017.68 | http://taxreview.law.pitt.edu 
disallowable exemptions under Internal Revenue Code (Code) provisions that do not apply to their tuition reductions, while others may fail to take advantage of exemptions to which they would be entitled. ${ }^{15}$

This article aims to clear up the confusion by providing an overview of the relevant rules and how they interact with one another. By exploring whether and when the various potential exclusions in the Code appertain to graduate education benefits for university faculty, the article seeks to determine how to identify - depending on the particular facts and circumstances - a tax position with respect to such benefits that is neither unduly cautious nor impermissibly aggressive. ${ }^{16}$

Part II of the article discusses $\S 117\left(\right.$ d)' $s{ }^{17}$ exclusion of "qualified tuition reductions" and how, under the IRS's interpretation, that exclusion does not apply to graduate tuition reductions for a university's regular faculty and staff. Although there are grounds on which to challenge the IRS's interpretation, a limitation in $\S 117(\mathrm{c})^{18}$ would most likely prevent the $\S 117(\mathrm{~d})$ exclusion from applying to most faculty graduate tuition reductions in any event. Part III of the article deals with $\S 127^{\prime} \mathrm{s}^{19}$ exclusion of the first $\$ 5,250$ of educational benefits that an employer provides in any calendar year

${ }^{15}$ One student commentator has aptly noted how the confusion and uncertainty surrounding the rules for deductibility of employment-related educational expenses under Regulation section 1.162-5, in particular, "increase[] the likelihood that taxpayers incorrectly treat the educational expenses-either failing to claim a deduction the regulation permits or, more importantly, claiming a deduction the regulation disallows." Vincent G. Kalafat, Note, Rethinking Treasury Regulation 1.162-5 and Slaying the Monster in the Education Tax Maze, 80 NOTRE DAME L. REV. 1985, 2021 (2005). As discussed in Part IV, infra, the $\S 1.162-5$ regulations are integral to any complete exemption of a graduate tuition reduction for university faculty. However, the authors of this article maintain that, at least when determining the proper tax treatment of graduate tuition reductions for university faculty, in particular, the single greatest source of confusion is the obscure interplay among $\S \S 117(\mathrm{~d}), 127$, and 132 . This is because the interrelationship among those provisions determines whether and when a working condition fringe exclusion for employer-provided education benefits under $\S 132(\mathrm{j})(8)$ (and, by extension, the rules for analyzing employment-related education expenses under Regulation section 1.162-5) might be even potentially applicable to a graduate tuition reduction.

${ }^{16}$ This article is intended solely for educational and informational purposes and does not constitute legal, accounting, or other tax advice to any person. Readers should consult their own attorneys, accountants, or other tax practitioners for guidance as to their particular tax matters and their specific situations.

\footnotetext{
${ }^{17}$ I.R.C. $§ 117(d)$.

${ }^{18} I d . \S 117(\mathrm{c})(1)$.

${ }^{19} I d . \S 127(\mathrm{a})$.
}

Pitt Tax Review | ISSN 1932-1821 (print) 1932-1996 (online)

DOI 10.5195/taxreview.2017.68 | http://taxreview.law.pitt.edu 
under an educational assistance program memorialized in a written plan that meets certain particular conditions. Although $\S 127$ can exclude the first $\$ 5,250$ of a faculty graduate tuition reduction when it applies, the various detailed requirements of a $\S 127$ plan $^{20}$ _including that the plan not discriminate in favor of the employer's "highly compensated employees"may make the provision inapplicable in a number of cases.

In Part IV, the article discusses the working condition fringe exclusion under $\S 132(a)(3)^{21}$ and explains when a given faculty graduate tuition reduction would or would not come within $\S 132(\mathrm{~d})$ 's definition of a "working condition fringe." 22 Part V examines the IRS's position on working condition fringe exclusions for graduate tuition reductions. If a faculty graduate tuition reduction constitutes a working condition fringe, and if the first $\$ 5,250$ of the tuition reduction is excludable under $\S 127$, then the IRS will allow an exclusion of the remainder of the reduction under $\S 132(\mathrm{a})(3)$. Under current IRS policy, however, the working condition fringe exclusion cannot apply to a graduate tuition reduction unless $\S 127$ also applies. Part V describes how the IRS's position is at odds with both the express language and the legislative history of the applicable Code sections and is also inconsistent with applicable Treasury regulations. In so doing, Part V offers taxpayers a roadmap for challenging the IRS's policy and arguing that a faculty graduate tuition reduction can be excluded under $\S 132(\mathrm{a})(3)$, even when $\S 127$ does not also apply. Part VI is the conclusion.

\section{SECTION 117(d) DoEs Not PROVIDE AN EXCLUSION FOR GRADUATE TUITION REDUCTIONS TO FACULTY MEMBERS}

The first exclusion provision in the Code to which one might look when considering whether the amount of a faculty member's graduate tuition waiver must be included in the faculty member's gross income is $\S 117(d)(1)$, which states that "[g]ross income shall not include any qualified tuition reduction." ${ }^{23}$ Alas, however, that provision ultimately does not apply when a

\footnotetext{
${ }^{20} I d . \S 127(\mathrm{~b})$.

${ }^{21}$ Id. $\S 132(\mathrm{a})(3)$.

${ }^{22}$ Id. § 132(d).

${ }^{23}$ Id. $\S 117(\mathrm{~d})(1)$.
}

Pitt Tax Review | ISSN 1932-1821 (print) 1932-1996 (online) DOI 10.5195/taxreview.2017.68 | http://taxreview.law.pitt.edu 
university grants a tuition reduction for a graduate course to one of its fulltime faculty members. For the reasons described below, a graduate tuition reduction to regular faculty does not constitute a "qualified tuition reduction" that is excludable under $\S 117(\mathrm{~d})$.

Section 117(d)(2) defines a "qualified tuition reduction" as "the amount of any reduction in tuition provided to an employee of [an educational organization $^{24}$ ] for the education (below the graduate level)" 25 of the employee, ${ }^{26}$ the employee's spouse, or the employee's dependent child ${ }^{27}$ either at the employer-organization or at another educational organization. ${ }^{28}$ In the first instance, therefore, excludable "qualified tuition reductions" include only reductions of undergraduate tuition.

However, a subsequent paragraph within $\S 117(\mathrm{~d})$ provides that, under certain circumstances, a graduate tuition reduction can also constitute a qualified tuition reduction. Section 117(d)(5) states that, "[i]n the case of the education of an individual who is a graduate student at an educational organization ... and who is engaged in teaching or research activities for such organization," the definition of "qualified tuition reduction" in $\S 117(\mathrm{~d})(2)$ "shall be applied as if it did not contain the phrase "(below the graduate level)." " 29 In other words, when an educational institution reduces the tuition of a "graduate student" at such institution who performs "teaching or research activities" for that institution, the graduate student can exclude the amount of her graduate tuition reduction from her gross income. The

\footnotetext{
${ }^{24}$ The definition refers to tuition reductions made to "an employee of an organization described in section 170(b)(1)(A)(ii).” Id. § 117(d)(2). In turn, as part of a list of organizations, donations to which are deductible (within certain limits) as charitable contributions, § 170(b)(1)(A)(ii) describes "an educational organization which normally maintains a regular faculty and curriculum and normally has a regularly enrolled body of pupils or students in attendance at the place where its educational activities are regularly carried on."

${ }^{25} I d . \S 117(\mathrm{~d})(2)$ (emphasis added).

${ }^{26} I d . \S 117(\mathrm{~d})(2)(\mathrm{A})$.

${ }^{27}$ Section 117(d)(2)(B) refers to the education of "any person treated as an employee (or whose use is treated as an employee use) under the rules of section 132(h)." In turn, $\S 132(\mathrm{~h})$ provides that, for purposes of excluding certain employee fringe benefits under § 132(a)(1) and (2), an employee's surviving spouse is treated as the employee, and any use (of a good or service) by an employee's spouse or dependent children is treated as a use by the employee. Id. § 132(h)(1), (2).

${ }^{28} I d . \S 117(\mathrm{~d})(2)$.

${ }^{29} I d . \S 117(\mathrm{~d})(5)$.
}

Pitt Tax Review | ISSN 1932-1821 (print) 1932-1996 (online)

DOI 10.5195/taxreview.2017.68 | http://taxreview.law.pitt.edu 
question thus becomes whether a university's full-time faculty member who simultaneously pursues (at reduced tuition) graduate studies at the university would constitute such a "graduate student" performing such "teaching activities" for purposes of $\S 117(\mathrm{~d})(5)$. The Internal Revenue Service (IRS) has determined that the answer to that question is "no."

\section{A. The IRS Has Determined that \$ 117(d)(5) Does Not Apply to Faculty Graduate Tuition Reductions}

In 1990, a university requested a private letter ruling "as to whether the graduate level tuition benefits provided to its faculty and staff members ... [were] excludable from gross income by the employees under section 117(d)." 30 The tuition benefit plan at issue did not cover the university's graduate teaching assistants. ${ }^{31}$ In response to the request, the IRS issued a ruling in which it concluded that graduate tuition benefits for the university's faculty and staff were not excludable under $\S 117(\mathrm{~d})(1) .{ }^{32}$ The IRS reached that conclusion because, on its interpretation of $\S 117(d)(5)$, qualified tuition reductions include graduate tuition benefits only for a school's graduate teaching and research assistants, and not for a school's regular faculty or other employees. ${ }^{33}$

\footnotetext{
${ }^{30}$ I.R.S. Priv. Ltr. Rul. 90-40-045 (July 10, 1990).

${ }^{31} \mathrm{Id}$.

${ }^{32} I d$.
}

${ }^{33} I d$. As the IRS noted in its ruling, "the distinction between regular faculty and staff, on the one hand, and graduate assistants, on the other, is an established one." Id. Graduate teaching and research assistants are graduate students (usually doctoral students) at a university who, in return for a stipend from the university, teach undergraduate courses (or assist the university's professors in the teaching of courses) in their fields of study and assist the university's professors in conducting academic research. As the U.S. Tax Court has observed, "[a]ll appointments as graduate teaching assistants at [a] university ... serve[] the dual purpose of providing financial aid to graduate students and of providing the members of the regular faculty with assistants." Jungreis v. Comm'r, 55 T.C. 581, 585 (1970). Appointment as a graduate assistant for any academic term is contingent on the student's "making satisfactory progress toward a graduate degree" at the university. $I d$. at 584 . Such "requirements do not apply to faculty and staff members" who receive tuition reductions from their employer-universities. I.R.S. Priv. Ltr. Rul. 90-40045 (July 10, 1990). Graduate teaching and research assistants are not permanent university employees, and their "years of service in that capacity [do not] count[] toward obtaining tenure." Jungreis, 55 T.C. at 585. Indeed, "[o]nly a very small percentage of the graduate teaching assistants employed by [a] university obtain employment as regular full-time teachers or faculty members at the university." Id. at 586. Instead, "[m]ost of them who become regular full-time teachers or faculty members obtain employment at [some other] college, university, or educational institution." Id. For all these reasons, in other contexts, "the Tax

Pitt Tax Review | ISSN 1932-1821 (print) 1932-1996 (online) DOI 10.5195/taxreview.2017.68 | http://taxreview.law.pitt.edu 
The university that requested the ruling maintained that "any individual enrolled in a graduate course for credit is a 'graduate student" under $\S 117(\mathrm{~d})(5) .{ }^{34}$ Thus, the university argued that, if such a person "also happens to be engaged in 'teaching or research activities' for the [educational] institution" in question, "then the individual comes within the scope of" $\S 117(\mathrm{~d})(5) .{ }^{35}$ If this were the clear meaning of $\S 117(\mathrm{~d})(5)$, then a graduate tuition reduction granted by a school to one of its full-time faculty members would constitute an excludable qualified tuition reduction.

The IRS rejected that argument, however, and instead found what it considers to be an ambiguity in the language of $\S 117(\mathrm{~d})(5)$. It posited that, "[i]f the term "graduate student"” really "encompasse[d] everyone who is taking a graduate-level course," then $\S 117(\mathrm{~d})(5)$ 's entire reference to "an individual who is a graduate student at an educational institution" would be "surplus language, since obviously the provision is only relevant to people who are taking such courses." ${ }^{36}$ Yet, reading that phrase as mere surplusage would be contrary to the "established rule of statutory construction that 'a statute should not be construed in a way that renders portions or phrases superfluous." ${ }^{37}$ From this, the IRS deduced that the phrase in question cannot be "simply redundant but ... instead [must be] intended to limit the scope" of $\S 117(\mathrm{~d})(5)$ "in some fashion. Exactly how it is limited, however, is not clear from the face of the statute." 38

Having found the provision to be unclear, the IRS next invoked two other well-known rules of statutory construction: "Where the text of a statute is ambiguous, the title or caption of the provision and its legislative history may be used as [aids] to interpreting the statute." ${ }^{39}$ The subheading of $\S 117(\mathrm{~d})(5)$, of course, is "Special rules for teaching and research

Court has distinguished faculty members from graduate assistants." I.R.S. Priv. Ltr. Rul. 90-40-045 (July 10, 1990) (citing Jungreis).

${ }^{34}$ I.R.S. Priv. Ltr. Rul. 90-40-045 (July 10, 1990).

${ }^{35} \mathrm{Id}$.

${ }^{36} I d$.

${ }^{37}$ Id. (quoting King v. Internal Revenue Serv., 688 F.2d 488, 491 (7th Cir. 1982)).

${ }^{38} \mathrm{Id}$.

${ }^{39}$ Id. (citing Maguire v. Comm'r, 313 U.S. 1, 9 (1941); Estate of Flanagan v. Comm'r, 18 T.C. $1241(1952))$.

Pitt Tax Review | ISSN 1932-1821 (print) 1932-1996 (online) DOI 10.5195/taxreview.2017.68 | http://taxreview.law.pitt.edu 
assistants." 40 That title plainly suggests that the provision applies solely to a university's graduate teaching and research assistants, and not to the school's faculty or staff. And, as the IRS noted, such interpretation is buttressed by the statute's legislative history. ${ }^{41}$

Section 117(d)(5) was added to the Code as part of the Technical and Miscellaneous Revenue Act of $1988 .^{42}$ The conference report accompanying the bill states that the provision "makes permanent the rule permitting tuition reduction benefits paid to graduate teaching and research [assistants] to be excluded from income under Section 117(d)." ${ }^{\text {43 }}$ This wording indeed indicates that Congress intended to provide an exclusion for graduate tuition reductions solely to graduate assistants, and not to any other members of the granting university's community. On this basis, the IRS "conclude[d] that $\S 117(\mathrm{~d})(5)$ of the Code does not apply to faculty and staff members of [a university] engaged in teaching and research activities, since they are not graduate teaching and research assistants." 44 Therefore, in the IRS's view, "graduate level tuition benefits provided to faculty and staff members of [a university] (and their spouses and dependent children) are not excludable from the gross income of the employees under $§ 117(\mathrm{~d})(1) .{ }^{445}$

\footnotetext{
${ }^{40}$ I.R.C. $\S 117(\mathrm{~d})(5)$.
}

${ }^{41}$ I.R.S. Priv. Ltr. Rul. 90-40-045 (July 10, 1990) ("The legislative history supports the interpretation reflected in the caption to $\S 117(\mathrm{~d})(5)$ of the Code.").

${ }^{42}$ Technical and Miscellaneous Revenue Act of 1988, Pub. L. No. 100-647, § 4001(b)(2), 102 Stat. 3342, 3643; see I.R.S. Priv. Ltr. Rul. 90-40-045 (July 10, 1990) (discussing addition of § 117(d)(5) to Code).

${ }^{43}$ H.R. REP. No. 100-1104, at 80 (1988). "Although the word 'assistants' is not in the paragraph of the conference report containing the conference agreement[,] the word 'assistants' is contained in the conference report's discussion of the House bill and the Senate amendment." I.R.S. Priv. Ltr. Rul. 90-40045 (July 10, 1990). For example, the report states that "[t]he Senate amendment is the same as the House bill, except that... the Senate amendment permits amounts paid to graduate teaching and research assistants to be excluded from income under . . the tuition reduction provision of section 117(d)." H.R. REP. No. 100-1104, at 79 (emphasis added).

${ }^{44}$ I.R.S. Priv. Ltr. Rul. 90-40-045 (July 10, 1990).

${ }^{45} \mathrm{Id}$.

Pitt Tax Review | ISSN 1932-1821 (print) 1932-1996 (online) DOI 10.5195/taxreview.2017.68 | http://taxreview.law.pitt.edu 


\section{B. The IRS's Interpretation of $\S 117(d)(5)$ Is Vulnerable to Challenge}

Interestingly, the IRS's interpretation of $\S 117(d)(5)$ appears never to have been challenged in court. ${ }^{46}$ Nonetheless, such interpretation-and, particularly, the IRS's threshold finding that the statutory language itself is ambiguous - is in fact quite susceptible to challenge. As an initial matter, the mere fact that the IRS has articulated its interpretation in a private letter ruling does nothing to foreclose any such challenge. Courts do not grant any deference to private letter rulings. ${ }^{47}$ That is especially true, of course, when a letter ruling contravenes the plain meaning of a Code provision. ${ }^{48}$ And, in the case of $\S 117(\mathrm{~d})(5)$, the denotation of the phrase "graduate student at an educational organization ... who is engaged in teaching or research activities for such organization"49 is plainly contrary to the conclusion in the IRS's ruling described above.

When accorded their ordinary and natural meanings, ${ }^{50}$ the words "graduate student at an educational organization" clearly and unambiguously refer to any person who is enrolled in a graduate course offered by the institution in question. Moreover, adopting that plain, commonsense reading of the text does not render any part of the statutory language redundant or

${ }^{46}$ A Lexis search conducted by the authors in January 2018 failed to reveal any reported decision construing $\S 117(\mathrm{~d})(5)$ in any federal court.

${ }^{47}$ An IRS private letter ruling cannot be cited as precedent by any taxpayer other than the one to whom it was issued. I.R.C. $\S 6110(\mathrm{k})(3)$. Thus, "private letter rulings . . . may not be relied upon by the general public when planning their affairs." CSI Hydrostatic Testers, Inc. v. Comm'r, 103 T.C. 398, 409 n. 10 (1994), aff'd, 62 F.3d 136 (5th Cir. 1995). For this reason, as the U.S. Tax Court and other courts have recognized, "private letter rulings are not entitled to the same judicial deference accorded to [Treasury] regulations." Id. (citing cases). "Accordingly, the interpretation of a statute or regulation provided by the Commissioner in a private letter ruling is entitled to no more deference than a litigating position before [a] [c]ourt." Id.

${ }^{48}$ See True Oil Co. v. Comm'r, 170 F.3d 1294, 1302 (10th Cir. 1999) (noting that a court "will not defer to an agency's interpretation of a statute," including an IRS interpretation of the Code in a private letter ruling, "if that interpretation conflicts with the plain language of the statute").

${ }^{49}$ I.R.C. $\S 117(d)(5)$.

50 "A fundamental canon of statutory construction instructs that in the absence of statutory definition, [a] court will accord words and phrases their ordinary and natural meaning, and in so doing, the court will avoid rendering the statutory language meaningless, redundant, or superfluous." Laubach v. Arrow Serv. Bureau, Inc., 987 F. Supp. 625, 629 (N.D. Ill. 1997) (emphasis added).

Pitt Tax Review | ISSN 1932-1821 (print) 1932-1996 (online)

DOI 10.5195/taxreview.2017.68 | http://taxreview.law.pitt.edu 
superfluous - the IRS's position notwithstanding. ${ }^{51}$ As the IRS correctly noted, the language at issue has to be "intended to limit the scope" of $\S 117(\mathrm{~d})(5)$ "in some fashion." 52 Contrary to the IRS's conclusion, however, ${ }^{53}$ the exact limitation of the provision's scope is clear on the face of statute itself: By its express terms, $\S 117(\mathrm{~d})(5)$ applies only to a "graduate student at an educational organization... who is engaged in teaching or research activities for such organization." 54 Thus, the clear and unambiguous language of the provision - discernable without dismissing any of the words as surplusage - is that it pertains to any person enrolled in a graduate course at a school if that person teaches or conducts research for the school. ${ }^{55}$ That group of persons, in turn, includes not only a university's graduate teaching and research assistants, but also any of a university's regular faculty members who take graduate courses at the institution.

Once the plain meaning of a statute's language is established, there can be no interpretive appeal to the wording of the statute's title or to the statute's legislative history. Under the very canons of statutory construction on which

${ }^{51}$ See supra text accompanying notes 36-38 (discussing the IRS's view that such a reading of such phrase would cause the phrase to be mere "surplus language" within $\S 117(d)(5))$.

${ }^{52}$ I.R.S. Priv. Ltr. Rul. 90-40-045 (July 10, 1990) (quoting King v. Internal Revenue Serv., 688 F.2d 488, 491 (7th Cir. 1982)).

${ }^{53}$ See supra text accompanying note 38

${ }^{54}$ I.R.C. § $117(\mathrm{~d})(5)$ (emphasis added).

${ }^{55}$ This is essentially the argument that the IRS (incorrectly) rejected in its private letter ruling. See I.R.S. Priv. Ltr. Rul. 90-40-045 (July 10, 1990) (“[T]he taxpayer argues that [§ 117(d)(5)’s] meaning ... is clear: any individual enrolled in a graduate course for credit is a 'graduate student,' and if that individual also happens to be engaged in 'teaching or research activities' for the institution, then the individual comes within the scope of the provision."); see also supra text accompanying notes 36-45 (explaining the IRS's rejection of such argument).

Pitt Tax Review | ISSN 1932-1821 (print) 1932-1996 (online) DOI 10.5195/taxreview.2017.68 | http://taxreview.law.pitt.edu 
the IRS relied, courts are to consult legislative history ${ }^{56}$ or section headings ${ }^{57}$ for interpretive guidance only if there is ambiguity in the statutory text. When the language of a statute is clear and unambiguous, that language controlsregardless of whether the statute's legislative history or title suggests a different meaning or intent. ${ }^{58}$ Accordingly, given the clear-cut meaning of $\S 117(\mathrm{~d})(5)$ described above, it is neither necessary nor appropriate to resort to the paragraph's subheading or its legislative history. Whether Congress intended to exclude graduate tuition reductions only for graduate assistants, and whether that intent is evinced by $\S 117(\mathrm{~d})(5)$ 's title, is irrelevant. All that matters is that the clear and unambiguous language of the statute itself provides that "qualified tuition reductions" include tuition reductions that a university provides to any student enrolled in a graduate course, so long as that student also teaches or performs research for the university.

${ }^{56}$ See United States v. Memorial Sloan-Kettering Cancer Ctr., 563 F.3d 19, $27-28$ (2d Cir. 2008) (in refusing to accord interpretive weight to legislative history of unambiguous Code section, the Second Circuit asserted that "“we [will] not resort to legislative history to cloud a statutory text that is clear"') (quoting Ratzlaf v. United States, 510 U.S. 135, 147-48 (1994) (alteration in original)); see also American Cmty. Builders, Inc. v. Comm'r, 301 F.2d 7, 13 (7th Cir. 1962) (finding that the Tax Court's resort to legislative history of unambiguous Code section was "plain error"). "Resort to legislative history has a place in judicial construction of statutes only when resort thereto is necessary to resolve a patent ambiguity in the language of the statute." American Cmty. Builders, $301 \mathrm{~F} .2 \mathrm{~d}$ at 13 (citing cases). Indeed, "the aid of legislative history is admissible only "to solve doubt and not to create it." Id. at 14 (quoting Railroad Comm'n of Wis. v. Chicago B. \& Q. R. Co., 257 U.S. 563, 589 (1922)). Thus, “"when the language used in a statute is clear and unambiguous its legislative history cannot control' interpretation of the statute." Id. at 13-14 (quoting Mandel Bros. Inc. v. Fed. Trade Comm'n, 254 F.2d 18, 22 (7th Cir. 1958)).

57 “"Titles and section headings cannot limit the plain meaning of statutory text when that text is clear" or otherwise "create ambiguity where none existed." Goodrich Corp. v. United States, 846 F. Supp. 2d 445, 454 (W.D.N.C. 2012) (quoting 1A Norman Singer \& Shambie Singer, Sutherland STATUTES AND STATUtory CONSTRUCTION $§ 18: 7$ n.11 (7th ed. 2017)) (emphasis added). Thus, "[f]or interpretive purposes," a statute's title "is of use only when it sheds light on some ambiguous word or phrase." Goodrich, 846 F. Supp. 2d at 454 (quoting United States v. Buculei, 262 F.3d 322, 331 (4th Cir. 2001)) (internal quotation marks omitted).

${ }^{58}$ See, e.g., Memorial Sloan-Kettering, 563 F.3d at 27 (declining to use legislative history to reach interpretation of Code section that was contradictory to clear and unambiguous statutory text); American Cmty. Builders, 301 F.2d at 13 (same); Goodrich, 846 F. Supp. 2d at 454 (declining to use statute's title to find meaning contrary to plain language of statute itself).

Pitt Tax Review | ISSN 1932-1821 (print) 1932-1996 (online)

DOI 10.5195/taxreview.2017.68 | http://taxreview.law.pitt.edu 
C. Even if the IRS's Reading of $\$ 117(d)(5)$ Were Rejected, $\S 117(c)$ Would Likely Thwart Any Exclusion for Graduate Faculty Tuition Reductions under $\$ 117(d)$

If courts were to adopt the above-described construction of $\S 117(d)(5)$, based on the clear and unambiguous statutory text, the precedents would of course establish that qualified tuition reductions-excludable under $\S 117(\mathrm{~d})(1)$ — could include graduate tuition reductions for university faculty. Nonetheless, even if $\S 117(\mathrm{~d})(5)$ were to be accorded its plain meaning, few (if any) faculty members would actually be able to exclude their graduate tuition reductions under $\S 117(\mathrm{~d})(1)$, in practice. ${ }^{59}$ The reason why the $\S 117(d)(1)$ exclusion would remain largely elusive to university facultyeven if "qualified tuition reductions" encompassed faculty graduate tuition reductions under $\S 117(\mathrm{~d})(5)$ - is that the excludability of any tuition reduction under $\S 117(\mathrm{~d})(1)$ is subject to the limitation set forth in $\S 117(\mathrm{c}) .^{60}$

Section 117(c)(1) provides that an otherwise-qualified tuition reduction is not excludable under $\S 117(\mathrm{~d})$ if it "represents payment for teaching, research, or other services by the student required as a condition for receiving the ... qualified tuition reduction." ${ }^{, 1}$ On first blush, this limitation would appear to turn $\S 117(\mathrm{~d})$ into something of an oxymoron. After all, any benefit that an employer transfers to an employee is compensation to the employee. ${ }^{62}$ So, if a qualified tuition reduction is excludable only if it is not a payment or compensation, but all employer-granted tuition reductions constitute compensation, does that mean that no qualified tuition reductions are ever excludable? The answer, of course, is "no"; such a reading would be nonsensical. Instead, the actual purpose of $\S 117(\mathrm{c})(1)$ - as it applies to

\footnotetext{
59 Perhaps this accounts for why no taxpayer appears ever to have challenged the IRS's interpretation of $\S 117(d)(5)$ - as it applies (or does not apply) to university faculty — in court.

${ }^{60}$ I.R.C. $\S 117(\mathrm{c})(1)$.

${ }^{61} I d$.

${ }^{62}$ See id. § 61(a)(1) (unless specifically excluded elsewhere in the Code, gross income includes all "[c]ompensation for services, including fees, commissions, fringe benefits, and similar items"); see also id. $\S 102(\mathrm{c})(1)$ (providing that no transfer from an employer to or for the benefit of an employee is treated as a gift, as opposed to income).
}

Pitt Tax Review | ISSN 1932-1821 (print) 1932-1996 (online) DOI 10.5195/taxreview.2017.68 | http://taxreview.law.pitt.edu 
qualified tuition reductions $s^{63}$-is to distinguish (1) employee tuition reductions that comprise a portion of the employee's salary or primary compensation from (2) those that constitute only a fringe benefit or ancillary compensation. $^{64}$ Under $\S 117(\mathrm{~d})$, as modified by $\S 117(\mathrm{c})(1)$, tuition reductions in the latter category are excludable, whereas those in the former category must be included in the employee's gross income.

The basic concern underlying $\S 117(c)(1)$ is that excludable fringe benefits have the potential to "erode the tax base by allowing parties to contract to divert taxable compensation into nontaxable forms." ${ }^{65}$ Significant "[t]ax evasion [could] occur" if employees were routinely able to " "trade" salary for nontaxable fringe benefits." 66 Thus, to prevent university employees from trading taxable salary for excludable tuition reductions, $\S 117(\mathrm{c})(1)$ disallows an exclusion under $\S 117(\mathrm{~d})$ if and to the extent that a qualified tuition reduction is granted as a substitute for wages or salary that the employee would otherwise receive. For example, imagine that assistant professors in a university's philosophy department generally receive a salary of $\$ 75,000$ per year. If the school grants a particular assistant professor of philosophy a qualified tuition reduction and that professor receives a salary of only $\$ 50,000$ per year, the first $\$ 25,000$ of the tuition reduction will be

${ }^{63}$ Section $117(\mathrm{c})(1)$ also prevents the exclusion by a student under $\S 117$ (a) of a qualified scholarship when it "represents payment for teaching, research, or other services by the student required as a condition for receiving the qualified scholarship."

${ }^{64}$ There is no comprehensive definition of "fringe benefit" in the Code. In the Treasury regulations, however, the term is essentially defined by example:

Examples of fringe benefits include: an employer-provided automobile, a flight on an employer-provided aircraft, an employer-provided free or discounted commercial airline flight, an employer-provided vacation, an employer-provided discount on property or services, an employer-provided membership in a country club or other social club, and an employer-provided ticket to an entertainment or sporting event.

Treas. Reg. §1.61-21(a)(1) (as amended in 2012). In other areas, the federal government has adopted straightforward definitions of "fringe benefits" that would apply equally well in the taxation context. For example, the Medicare Provider Reimbursement Manual states simply that "fringe benefits are amounts paid to, or on behalf of, an employee, in addition to direct salary or wages." Sarasota Mem'l Hosp. v. Shalala, 60 F.3d 1507, 1509 (11 th Cir. 1995) (quoting MEdiCARE Provider ReIMBURSEMENT MANUAL $\S 2144.1$ ) (internal quotation marks omitted).

${ }^{65}$ Dodge, supra note 3, at 745.

${ }^{66} \mathrm{Id}$. at 746.

Pitt Tax Review | ISSN 1932-1821 (print) 1932-1996 (online)

DOI 10.5195/taxreview.2017.68 | http://taxreview.law.pitt.edu 
treated as the equivalent of $\$ 25,000$ of salary, and the professor will have to include that $\$ 25,000$ in her gross income. ${ }^{67}$

Similarly, a qualified tuition reduction is treated as a salary-equivalent when the grant of the reduction is conditioned on the employee's agreement to remain in the school's employ for a certain future period. So, for example, imagine that our assistant professor of philosophy receives both the standard $\$ 75,000$ salary and a qualified tuition reduction - but, this time, imagine that she gets the tuition reduction only if she agrees to remain on the university's faculty for at least the following three years. Assume that the amount of the reduction (i.e., the difference between the tuition that the professor pays and the tuition that would ordinarily be payable for the same courses) is $\$ 30,000$. In that case, the qualified tuition reduction will be treated as an additional payment of $\$ 30,000$ for the performance of future services, and the professor will have to include the $\$ 30,000$ in her gross income. ${ }^{68}$

As noted above, a graduate tuition reduction to a university professor (to finance the professor's graduate studies at the university) is almost always conditioned on the professor's agreement to remain on the school's faculty during some certain period after the receipt of her graduate degree. ${ }^{69}$ Moreover, the authors suspect that, in the rare case in which a university would grant a graduate tuition reduction to a faculty member without receiving such an agreement in return, the salary that the faculty member would otherwise receive would be reduced by an amount equal to the amount of the tuition reduction. Either way, the graduate tuition reduction would "represent[] payment for teaching, research, or other services" under $\S 117(\mathrm{c})(1)$. As a result, the recipient professor could not exclude the tuition

\footnotetext{
${ }^{67}$ See Exclusion from Gross Income of Qualified Scholarships, Prop. Treas. Reg. § 1.117-6(d)(2), (5), ex. (5), 1988-2 C.B. 840, 845-46. The portion of the tuition reduction amount that is allocated to compensation for services and is thus includible in gross income pursuant to $\S 117(\mathrm{c})(1)$ is "determined by reference to the rate of compensation ordinarily paid for similar services performed by an individual who is not the recipient of a" tuition reduction. Stuart Lazar, Schooling Congress: The Current Landscape of the Tax Treatment of Higher Education Expenses and a Framework for Reform, 2010 MicH. ST. L. REV. 1047, 1085. Of course, if the amount of a qualified tuition reduction exceeds such ordinary rate of compensation, the excess remains excludable under $§ 117$ (d). See Dodge, supra note 3, at 724 (discussing Proposed Regulation section 1.117-6(d)(5), ex. (5)). In practice, however, any such excess is likely to occur only in the case of a graduate teaching and research assistant - not in the case of a full-time faculty member.

${ }^{68}$ See Exclusion from Gross Income of Qualified Scholarships, Prop. Treas. Reg. § 1.117-6(d)(2), (5), exs. (1), (2), 1988-2 C.B. $840,845$.

${ }^{69}$ See supra note 2 .
}

Pitt Tax Review | ISSN 1932-1821 (print) 1932-1996 (online) DOI 10.5195/taxreview.2017.68 | http://taxreview.law.pitt.edu 
reduction under $\S 117(\mathrm{~d})$. Because the $\S 117(\mathrm{c})(1)$ limitation would likely apply to virtually all graduate tuition reductions granted to university faculty, those tuition reductions would virtually never be excludable under $\S 117(\mathrm{~d})$ - even if such reductions were held to come within the scope of "qualified tuition reductions" by operation of $\S 117(\mathrm{~d})(5)$.

Given the position the IRS has taken, and given how $\S 117(\mathrm{c})$ would apply even if the IRS's position were rejected, the bottom line is that $\S 117(\mathrm{~d})$ does not provide an exclusion for a graduate tuition reduction granted by a university to one of its faculty members. That being the case, are there any other exclusions elsewhere in the Code that might be available?

\section{SECTION 127 MAY PROVIDE A PARTIAL EXCLUSION FOR GRADUATE TUITION REDUCTIONS TO FACULTY MEMBERS, BUT ONLY IN CERTAin CASES}

\section{A. Section 127 Could Exclude up to \$5,250 of Graduate Faculty Tuition Reductions per Year}

One provision that may apply to at least a portion of certain graduate tuition reductions for faculty is the exclusion of up to $\$ 5,250$, annually, of employer-provided educational assistance under $\S 127 .^{70}$ If an employer ${ }^{71}$ furnishes educational assistance ${ }^{72}$ to an employee under an educational

${ }^{70}$ I.R.C. $\S 127(a)$.

${ }^{71}$ In contrast to $\S 117(\mathrm{~d}), \S 127$ applies to qualified educational assistance provided by any employer, not only by employers that themselves are educational institutions. See Dodge, supra note 3, at $736(\S 127$ "potentially applies to employees of any kind of employer, whereas $\S 117(\mathrm{~d})$ benefits only employees of educational institutions").

${ }^{72}$ I.R.C. $§ 127(c)(1)$ defines "educational assistance" to include:

(A) the payment, by an employer, of expenses incurred by or on behalf of an employee for education of the employee (including, but not limited to, tuition, fees, and similar payments, books, supplies, and equipment), and (B) the provision, by an employer, of courses of instruction for such employee (including books, supplies, and equipment) ....

The definition of "educational assistance" specifically excludes any "payment for, or the provision of, tools or supplies which may be retained by the employee after completion of a course of instruction, or meals, lodging, or transportation." Id. Nor does the term "include any payment for, or the provision of any benefits with respect to, any course or other education involving sports, games, or hobbies." Id.

Pitt Tax Review | ISSN 1932-1821 (print) 1932-1996 (online)

DOI 10.5195/taxreview.2017.68 | http://taxreview.law.pitt.edu 
assistance program that meets the requirements of $\S 127(\mathrm{~b}){ }^{73} \S 127(\mathrm{a})$ provides that the employee may exclude the value of such assistance from her gross income ${ }^{74}$ up to an exclusion limit of $\$ 5,250$ per year. ${ }^{75}$ Not only does the exclusion apply when an employer pays an employee's tuition at a school separate from the employer; ${ }^{76}$ it also applies when the employer itself provides courses directly to an employee ${ }^{77}$ - for example, when a school provides courses to its own employees for little or no tuition. For employerprovided educational assistance to qualify for exclusion under $\S 127$, it is not necessary for the employee's course of study to be related to the employee's current job function or duties. ${ }^{78}$

In some ways, the exclusion under $\S 127$-as it potentially pertains to school-employees' tuition reductions-is narrower in scope than $\S 117(\mathrm{~d})$ 's exclusion of qualified tuition reductions. ${ }^{79}$ The most obvious example is that,

${ }^{73}$ Id. § 127(b); see infra Parts III.B and III.C.

${ }^{74}$ I.R.C. $\S 127(\mathrm{a})(1)$.

${ }^{75} I d . \S 127(\mathrm{a})(2)$.

${ }^{76} \mathrm{Id}$. $127(\mathrm{c})(1)(\mathrm{A})$. This includes both payments by an employer directly to a school, on behalf of an employee, and reimbursements to an employee for payments that the employee made to a school. See Dodge, supra note 3, at 721.

${ }^{77}$ I.R.C. $\S 127(\mathrm{c})(1)(\mathrm{B})$.

${ }^{78}$ See Case Study: Using a Qualified EAP, 34 TAX ADVISER 570, 572 (Albert B. Ellentuck ed., 2003) (noting that employer-financed coursework can qualify as educational assistance under $\S 127$, "even though it is not directly related to [employee's] current job and may help qualify him for a new trade or business"); Edmund D. Fenton Jr., Employer-Provided Education Benefits, J. ACCOUNTANCY, Sept. 2004, at 49, 52 (noting that, under $\S 127$, excluded education does not "have to be job-related" or "closely related to job function"); Lazar, supra note 67, at 1088-89 (noting that courses constituting educational assistance under $\S 127$ "do not have to be job related and can help employees meet minimum requirements for current work or to prepare for a new career"). Because $\S 127$ does not require the education in question to be related to the employee's particular work for the employer, the exclusion under $\S 127$ applies to the cost or value of certain coursework that would not come within the scope of the working condition fringe exclusion for employer-provided education benefits under $\S 132(a)(3)$ and (j)(8). See infra notes 152-71 (discussing working condition fringe exclusion).

${ }^{79}$ For instance, $\S 127$ excludes only educational assistance that an employer provides specifically for the benefit of an employee - not any educational assistance that an employer provides for an employee's spouse or dependents. I.R.C. § 127(b)(1) (for educational assistance to be excludable under $\S 127(\mathrm{a})$, it must be provided under an educational assistance program "for the exclusive benefit of [the employer's] employees") (emphasis added); see also Fenton, supra note 78, at 50 ("Spouses and dependents are not covered [under § 127]."); Lazar, supra note 67, at 1088 (noting that, under § 127, "the value of educational assistance provided to an employee's spouse or dependents is treated as compensation income"). In contrast, as noted above, $\S 117(\mathrm{~d})$ provides an exclusion for qualified tuition

Pitt Tax Review | ISSN 1932-1821 (print) 1932-1996 (online) DOI 10.5195/taxreview.2017.68 | http://taxreview.law.pitt.edu 
when it applies, $\S 127$ excludes only the first $\$ 5,250$ of any such tuition reduction in any calendar year. ${ }^{80}$ In other important ways, however, $\S 127$ is far broader in scope than $\S 117(\mathrm{~d})$. Perhaps most significantly (at least in the context of this discussion), $\S 127$ currently excludes employer-provided assistance for an employee's graduate, as well as undergraduate, education. ${ }^{81}$ In addition, $\S 127$ excludes employer-provided educational benefits that otherwise constitute compensation for the employee's services. ${ }^{82}$ As a result,

reductions granted not only for undergraduate studies by an educational organization employee, but also for undergraduate studies by the employee's spouse or dependents. See supra note 27 and accompanying text.

${ }^{80}$ I.R.C. $§ 127(a)(2)$ (maximu $\mathrm{m} \$ 5,250$ exclusion from gross income of educational assistance provided during a calendar year). As originally enacted in 1978, § 127 did not include any annual exclusion cap. Lazar, supra note 67, at 1087 n.264. In 1984, however, $\S 127$ was amended to place an annual cap of $\$ 5,000$ on the exclusion. Id. In 1986, the provision was further amended to increase the annual exclusion cap to \$5,250. Id.; see Tax Reform Act of 1986, Pub. L. No. 99-514, § 1162(a)(2), 100 Stat. 2085, 2510 (1986). This limit on the exclusion amount is not indexed for inflation and thus remains the same today as it was in 1986. Lazar, supra note 67, at $1087 \mathrm{n} .264$. Thus, if an employer provides qualified educational assistance to an employee in an amount greater than $\$ 5,250$ during a single calendar year, the portion of the assistance in excess of $\$ 5,250$ must be included in the employee's gross income. Of course, as the cost of living has increased during the last several decades, the tax benefit under $§ 127$ has declined in real value (and that decline is likely to continue in future years). Today, at least in the context of exclusion of the value of employer-provided graduate-school tuition, § 127 (when it applies at all) operates as a partial exclusion at best—given current graduate tuition rates. According to educational service provider Peterson's, the average annual graduate-program tuition in 2016 was approximately $\$ 30,000$ at public universities and approximately $\$ 40,000$ at private universities. See Is the Cost of a Graduate Degree Worth It?, PETERSON's (Mar. 31 2016), https://www.petersons.com/graduateschools/cost-graduate-degree-worth.aspx\#/sweeps-modal.

81 "Educational assistance provided by $\S 127$ includes both graduate and undergraduate courses." Lazar, supra note 67, at 1088; see also Dodge, supra note 3, at 721 (educational assistance under $\S 127$ is "broadly defined and includ[es] graduate and professional education"). The § 127 exclusion has applied to graduate educational assistance for all taxable years since those beginning after December 31, 2001. See Fenton, supra note 78, at 50. However, "[t]he exclusion has not always applied to graduate courses." Lazar, supra note 67, at 1088 n.271. For instance, amendments to $§ 127$ in 1988 and 1996, respectively, prevented the exclusion from applying to graduate education for taxable years beginning between 1989 and 1990 or taxable years beginning between 1997 and 2001. See id. (outlining history of $\S 127$ 's alternating applicability or inapplicability to graduate education assistance). When Congress disallowed any $\S 127$ exclusion for graduate education in past periods, it did so in an effort to balance support for educational assistance with the need to reduce federal budget deficits. See id. at 1116 n.448 (quoting House Report for 1996 amendment to § 127). As budget deficits and the national debt continue to be serious concerns, future congressional restrictions on $\S 127$ 's application to graduate studies would not be entirely surprising.

${ }^{82}$ This is in marked contrast to the denial under $\S 117$ (c) of any exclusion under $\S 117$ (d) in the case of a qualified tuition reduction that "represents payment for teaching, research, or other services" performed (or to be performed) by the recipient of the tuition reduction. I.R.C. $§ 117$ (c)(1). See Dodge, supra note 3, at 721 ("Since section 127 excludes what would otherwise be includible compensation, it is

Pitt Tax Review | ISSN 1932-1821 (print) 1932-1996 (online)

DOI 10.5195/taxreview.2017.68 | http://taxreview.law.pitt.edu 
the factors that preclude any exclusion of graduate tuition reductions for university faculty under $\S 117$ (d) do not prevent the exclusion thereof under $\S 127$. Moreover, proposed Treasury regulations under $\S 117$ confirm the government's position that an employer-provided tuition reduction may still be excludable under $\S 127$ when such tuition reduction does not qualify for exclusion under $\S 117(\mathrm{~d}){ }^{83}$

Given the foregoing parameters of $\S 127$, when a university provides a faculty member with a graduate tuition reduction pursuant to an educational assistance program that meets the requirements of $\S 127$ (b), the first $\$ 5,250$ of that tuition reduction is excludable from the faculty member's gross income. Imagine, for example, that a university professor pursues a doctorate in accounting at her home institution. The annual tuition for a doctoral student at the university is $\$ 30,000$, but the school provides its doctoral courses to the professor tuition-free. Assuming the university grants the tuition reduction under a program that the university maintains in accordance with $\S 127(\mathrm{~b})$, the professor can exclude from her gross income the first $\$ 5,250$ of the tuition reduction that she receives during a given calendar year. Assuming no other exclusion provision (besides $\S 127$ ) applies, the professor would have to include the remaining $\$ 24,750$ of the tuition reduction in her gross income for the corresponding taxable year.

\section{B. A $\$ 127$ Exclusion Is Available Only for Educational Benefits that Are Provided Pursuant to a Written Plan that Meets Certain Specific Requirements}

When some taxpayers (and, for that matter, some tax advisors) first encounter $\S 127$, they mistakenly think that it simply excludes the first $\$ 5,250$ of any educational assistance that any employer provides to any employee. In actuality, however, the exclusion is considerably narrower than that. As noted above, $\S 127$ (a) permits an employee to exclude employer-

in potential conflict with section 117(c).”). For further discussion of $\S 117(\mathrm{c})$ 's limitation of $\S 117(\mathrm{~d})$, see supra Part II.C.

${ }^{83}$ See Exclusion from Gross Income of Qualified Scholarships, Prop. Treas. Reg. § 1.117-6(b)(1), 1988-2 C.B. 840,844 (noting that, generally, the amount of a scholarship grant not excludable under $\$ 117$ is includible in gross income, but specifically referencing the availability of the $\S 127$ exclusion for certain amounts that qualify as "educational assistance payments").

Pitt Tax Review | ISSN 1932-1821 (print) 1932-1996 (online) DOI 10.5195/taxreview.2017.68 | http://taxreview.law.pitt.edu 
provided educational assistance from gross income only if such assistance was provided pursuant to an "educational assistance program" that meets all of the requirements set forth in $\S 127(\mathrm{~b}) .{ }^{84}$ As discussed below, the $\S 127(\mathrm{~b})$ requirements significantly limit the availability of the $\S 127$ exclusion. Indeed, several of those requirements have the potential to disallow university professors from excluding any portion of their graduate tuition reductions under $\S 127$, in a number of scenarios.

Section 127 (b) requires, among other things: ${ }^{85}$ (1) that an employer's educational assistance program be a separate program, set forth in writing; ${ }^{86}$ (2) that the program be for the exclusive ${ }^{87}$ benefit of the employer's employees - or a particular class of employees ${ }^{88}$ - and not for the benefit of any employees' spouses or dependents, ${ }^{89}$ (3) that the employer provide "[r] easonable notification" of the plan to all eligible employees; ${ }^{90}$ and (4) that the program not discriminate in favor of "highly compensated" employees. ${ }^{91}$ There are many cases in which a university might provide graduate tuition reductions to its faculty members in a manner that violates one or more of these requirements.

${ }^{84}$ See I.R.C. $§ 127(a)(1)$ (excluding employer-provided educational assistance "if the assistance is furnished pursuant to a program which is described in [§ 127(b)]”) (emphasis added).

${ }^{85}$ In addition to the requirements listed immediately below, $\S 127(\mathrm{~b})(4)$ requires that an educational assistance program "not provide eligible employees with a choice between educational assistance and other remuneration includible in gross income." Id. § 127(b)(4). Also, § 127(b)(3) prohibits more than five percent of the amounts provided pursuant to an educational assistance plan from being provided to those with a greater-than-five-percent ownership interest in the employer. Id. §127(b)(3). This latter requirement is not likely to be relevant in the context of educational assistance provided to employees of a not-for-profit university, however.

${ }^{86} I d . \S 127(\mathrm{~b})(1)$.

${ }^{87} I d$.

${ }^{88}$ To be reasonable, the classification of employees eligible to receive the educational assistance must not be discriminatory in favor of "highly compensated" employees. $I d$. $\S 127(\mathrm{~b})(2)$. The definition of "highly compensated employee," for purposes of this rule, is discussed infra notes 105-08 and accompanying text. For a discussion of what constitutes a reasonable classification for this purpose, and what constitutes discrimination for the benefit of highly compensated employees, see infra text accompanying notes 109-32.

${ }^{89}$ See supra note 79.

${ }^{90}$ I.R.C. $\S 127(\mathrm{~b})(6)$.

${ }^{91}$ Id. § 127(b)(2).

Pitt Tax Review | ISSN 1932-1821 (print) 1932-1996 (online)

DOI 10.5195/taxreview.2017.68 | http://taxreview.law.pitt.edu 
First, if the university does not have a written plan for the sole purpose of providing its employees with educational assistance that is excludable under $\S 127$, then the $\S 127$ exclusion will not apply to any educational benefit that the university provides to an employee. ${ }^{92}$ Nor can a university purport to satisfy the written-program requirement by claiming that a graduate tuition reduction to a faculty member is provided in accordance with the university's broader policy of giving tuition reductions to university employees and their spouses or dependents. Rather, for a plan to provide benefits that are excludable under $\S 127$, the plan must pertain only to educational assistance under $\S 127$ and must cover only employees or a reasonable class of employees. ${ }^{93}$ And, assuming such a $\S 127$ program exists in the first place, the employer must take reasonable steps to notify all eligible employees that the benefits thereunder are available. ${ }^{94}$

Plainly, it would be to the advantage of any university's employees for the university to adopt a $\S 127$ educational assistance program. With such a program in place, the employees would be entitled to exclude (at least partially) educational benefits that might not come within the scope of any of the Code's other exclusion provisions. ${ }^{95}$ Unfortunately, though, $§ 127$ programs "can be quite costly and burdensome for employers to

${ }^{92}$ For one straightforward example of such a written plan, see the Wayne State University Section 127 Educational Assistance Plan (the "Wayne State $§ 127$ Plan"), developed by Wayne State University in Detroit, Michigan. Wayne State Univ., Section 127 Educational Assistance Plan (2013), http://hr.wayne.edu/tcw/tuition-assistance/section127-plandocument.pdf.

${ }^{93}$ For example, the Wayne State $\S 127$ Plan explicitly contemplates that Wayne State University may offer certain employee benefits that might qualify for exclusion from the employee's gross income under Code provisions other than $\S 127$-including, inter alia, undergraduate tuition assistance to employees and their dependents that may be excludable under $\S 117$ (d). See id. § 1.02. The Wayne State $\S 127$ Plan expressly states that policies for providing those benefits do not constitute part of the $\S 127$ plan and that " $[\mathrm{t}]$ he educational assistance provided under [the $\S 127$ plan] is provided in addition to such other benefits." Id.

${ }^{94}$ Presumably, § 127(b)(6)'s reasonable notification requirement is relatively easy to satisfy, once a formal educational assistance program exists. For example, an employer could post its plan on its website, email the plan to eligible employees, or include the plan in an employee handbook.

${ }^{95}$ See E. Drew Cheney, Taxability of Employer-Provided Educational Assistance, 43 TAX ADVISER 514, 516 (2012) (suggesting that, for employers that provide educational benefits that might not be excludable under other Code provisions, "it would make sense to consider implementing a $[\S] 127$ program to reduce uncertainty and to maximize the number of instances in which the employer can provide educational assistance on a tax-free basis").

Pitt Tax Review | ISSN 1932-1821 (print) 1932-1996 (online) DOI 10.5195/taxreview.2017.68 | http://taxreview.law.pitt.edu 
administer." ${ }^{96}$ Although $\S 127$ does not require an educational assistance program to be funded, ${ }^{97}$ the ministerial expenses can be significant. ${ }^{98}$ Moreover, "[t]he requirement that the program be nondiscriminatory [in favor of highly compensated employees] can make it [costlier,] depending on how many eligible employees take advantage of it." 99 As a result, not all schools will consider it worthwhile to create and maintain such a program.

Consider, for example, a university that provides the following (and only the following) educational benefits to its employees: (1) undergraduate tuition reductions for its full-time staff and for the spouses and dependents of its full-time faculty, and (2) graduate tuition reductions for certain of its fulltime faculty. In such a case, all of those benefits other than the graduate tuition reductions will be excludable under $\S 117(\mathrm{~d}) .{ }^{100}$ Now, imagine that the university's policy is not to make graduate tuition reductions available to all faculty members - or to any subgroup of faculty, generally. Instead, assume that the university grants graduate tuition reductions only to particular faculty members when it determines that there is a specific advantage in doing so. ${ }^{101}$ Or, alternatively, assume that the university provides graduate tuition reductions only on an ad-hoc basis to particularly well-regarded faculty members. ${ }^{102}$ If a school decides whether and when to

${ }^{96}$ Fenton, supra note 78 , at 50.

${ }^{97}$ I.R.C. $\$ 127($ b)(5). "Thus, if [an employer] has no available cash, it can put the plan on hold until cash flow improves." Fenton, supra note 78, at 51.

${ }^{98}$ Fenton, supra note 78, at 50 (noting, for instance, that "for each year of the program's existence, the employer must file form 5500 by the last day of the seventh month after the program yearend to report detailed plan information," and referring more generally to the administrative costs associated with "a formal, written plan" that meets all of the tests under $\S 127(\mathrm{~b}))$.

${ }^{99} I d$. at $50-51$.

${ }^{100}$ This assumes that the $\S 117$ (c) limitation does not apply with respect to the otherwise-excludable qualified tuition reductions. See supra Part II.C. It also assumes that the school's provision of such otherwise-excludable qualified tuition reductions does not violate $\S 117(\mathrm{~d})(3)$ 's nondiscrimination requirement. See infra note 124.

${ }^{101}$ Under this kind of approach, for example, a university might decide to provide a graduate tuition reduction to an instructor whom it hires for a tenure-track position, on the condition that she complete her doctorate (at the school) prior to the date of the tenure decision. Or, a university might provide a graduate tuition reduction to a long-tenured faculty member who has only a master's degree, to enable her to attain her doctorate (at the school) to conform to current qualification standards.

${ }^{102}$ As an example of this kind of approach, imagine a university whose faculty contains a nationally reputed biology professor. Imagine further that the professor wishes to pursue her second $\mathrm{PhD}$, in

Pitt Tax Review | ISSN 1932-1821 (print) 1932-1996 (online)

DOI 10.5195/taxreview.2017.68 | http://taxreview.law.pitt.edu 
award faculty graduate tuition reductions under one of these case-by-case approaches, the school simply may not have any written policy that governs those decisions-let alone a written plan that meets all of $\S 127(\mathrm{~b})$ 's requirements. ${ }^{103}$

C. Graduate Faculty Tuition Reductions Cannot be Excluded under \& 127 if They Are Provided Pursuant to a Plan that Discriminates in Favor of the University's Highly Compensated Employees

Even when a university provides graduate tuition reductions to certain classes of eligible employees under a separate, written plan that would otherwise comply with $\S 127(\mathrm{~b})$, there is still a significant potential pitfall: Section $127(\mathrm{~b})(2)$ provides that the benefits will not be excludable under $\S 127$ (a) if the IRS determines the school's classification of eligible employees to be "discriminatory in favor of [the university's] highly compensated employees." 104 For this purpose, whether an employee is deemed to be a "highly compensated employee"105 for a particular year depends on (1) whether the employee's compensation in the preceding year exceeded a certain threshold amount ${ }^{106}$ and (2) whether the employee had more than a five-percent ownership interest in the employer at any time

chemistry. As an inducement to the professor to remain on the faculty, the university might grant a graduate tuition reduction to enable her to pursue her chemistry $\mathrm{PhD}$ at the school for little or no cost.

${ }^{103}$ Of course, even if there were a written plan, there probably would not be any reasonable class of eligible employees in any of these scenarios - in which case the plan would fail to meet $\S 127(\mathrm{~b})(2)$ 's eligibility requirement. I.R.C. $\S 127(b)(2)$; see infra text accompanying notes 126-27.

104 I.R.C. $\S 127(\mathrm{~b})(2)$. To pass muster under $\S 127(\mathrm{~b})$, an educational assistance program must "benefit employees who qualify under a classification set up by the employer and found by the Secretary not to be discriminatory in favor of employees who are highly compensated employees." Id.

105 The nondiscrimination requirement in $\S 127(\mathrm{~b})(2)$ relates to highly compensated employees "within the meaning of $\S 414(q)$." Id.

${ }^{106} I d . \S 414(\mathrm{q})(1)(\mathrm{B})(\mathrm{i})$ (originally providing that a "highly compensated employee" includes any employee who "had compensation from the employer in excess of $\$ 80,000$ " for the preceding year). The Secretary of the Treasury is required to adjust the threshold compensation figure in $\S 414(q)(1)(B)(i)$ annually, based on a formula for cost-of-living adjustments set forth in $\S 415(\mathrm{~d})$. Id. $\S 414(\mathrm{q})(1)$ (flush language). The IRS announces the applicable compensation figure for a particular year in a news release, usually in October of the prior year. If more than twenty percent of an employer's employees have compensation in excess of the applicable threshold amount for a particular year, the employer can elect to limit its "highly compensated employees" to a "top-paid group" consisting of the twenty percent of its employees with the highest compensation. Id. § 414(q)(1)(B)(ii), (3).

Pitt Tax Review | ISSN 1932-1821 (print) 1932-1996 (online) DOI 10.5195/taxreview.2017.68 | http://taxreview.law.pitt.edu 
during the current or preceding year. ${ }^{107}$ For example, an employee is "highly compensated" for 2017 if either (1) she received more than $\$ 120,000^{108}$ in compensation from her employer in 2016 or (2) she had a greater-than-fivepercent equity interest in the employer at any time during 2016 or 2017.

The nondiscrimination rule in $\S 127(\mathrm{~b})(2)$ essentially requires an employer not to make benefits under an educational assistance program available ${ }^{109}$ principally or disproportionately to the employer's most highly compensated employees. But, just how skewed toward highly compensated employees must the availability of the educational assistance be, for a program to run afoul of that rule? In other words, what is the specific standard by which to determine whether a given educational assistance program is discriminatory? There is a surprising dearth of authorities in which the IRS

${ }^{107} I d$. $\S 414$ (q)(1)(A) (a "highly compensated employee" includes any employee who was a "5percent-owner" at any time during the current or preceding year). For this purpose, a " 5 -percent-owner" is as defined in $\S 416(\mathrm{i})(1) . I d$. $\S 414(\mathrm{q})(2)$. Under $\S 416(\mathrm{i})(1)$, a "5-percent-owner" of an employer organized as a corporation is a person who owns (or is deemed to own, under $\S 318$ 's stock attribution rules) more than five percent of the outstanding stock of the corporation or stock possessing more than five percent of the voting power of all stock of the corporation. Id. § 416(i)(1)(B)(i)(I). In the case of an employer that is not organized as a corporation, a " 5 -percent-owner" is any person who owns more than a five-percent capital interest or profits interest in the employer. Id. § 416(i)(1)(B)(i)(II).

${ }^{108}$ For 2017, the applicable compensation amount under $\S 414$ (q)(1)(B)(i) is $\$ 120,000$. See I.R.S. News Release IR-2016-141 (Oct. 27, 2016). Thus, any employee who earned more than $\$ 120,000$ in compensation from her employer for 2016 is a "highly compensated employee" of the employer in 2017 (subject to the employer's ability to elect to limit its highly compensated employees to its top-paid group under $\S 414(q)(1)(B)(i i))$. The $\S 414(q)(1)(B)(i)$ compensation amount has remained constant since 2015. See I.R.S. News Release IR-2014-99 (Oct. 23, 2014) (announcing increase in amount from $\$ 115,000$, for 2014 , to $\$ 120,000$ for 2015 ).

${ }^{109}$ The only relevant inquiry under $\S 127(\mathrm{~b})(2)$ is whether educational assistance is available chiefly to highly compensated employees. As long as non-highly compensated employees have the requisite access to the educational assistance if they want it, the fact that highly compensated employees choose to take advantage of the benefits more often than their non-highly compensated colleagues does not render an educational assistance program discriminatory. I.R.C. §127(c)(5)(A) (educational assistance program not to be deemed ineligible under $\S 127(\mathrm{~b})(2)$ simply because "of utilization rates for the different types of educational assistance made available under the program"); see also Dodge, supra note 3, at $737 \mathrm{n} .229$ (discussing same). In determining whether educational assistance is in fact available to a particular employee or class of employees, certain common-sense conditions that an employer might impose are not considered to be restrictions on access. In particular, if an employer makes tuition assistance to an otherwise-eligible employee contingent on (1) the employee's successful completion of a course or attainment of a certain grade in a course or (2) the employee's remaining with the employer for one year after completing a course, those requirements do not constitute limitations on availability of the assistance. I.R.C. § 127(c)(5)(B); Treas. Reg. § 1.127-2(e)(2)(ii) (1983).

Pitt Tax Review | ISSN 1932-1821 (print) 1932-1996 (online)

DOI 10.5195/taxreview.2017.68 | http://taxreview.law.pitt.edu 
or a court has addressed that question. ${ }^{110}$ However, a Treasury regulation under $\S 127$ indicates that the appropriate nondiscrimination test for a $\S 127$ program is the same detailed test that Treasury regulations under $\S 410(\mathrm{~b})$ prescribe for determining whether a deferred compensation plan is discriminatory. ${ }^{111}$

Regulation section 1.127-2(e)(1) instructs that "whether any classification of employees [discriminates in favor of highly compensated employees for purposes of $\S 127(b)(2)]$ will generally be determined by applying the same standards as are applied under $\S 410(\mathrm{~b})(1)(\mathrm{B}) .,{ }^{, 12}$ When

${ }^{110}$ A Lexis search conducted by the authors in January 2018 failed to reveal any reported decision construing $§ 127(b)(2)$, or the nondiscrimination requirement thereunder, in any federal court. Nor has the IRS offered a detailed construction of $\S 127(\mathrm{~b})(2)$ 's nondiscrimination standard in any private letter ruling or other administrative pronouncement. In the majority of private letter rulings applying $\S 127$ to a given educational assistance program, the IRS has noted $\S 127(\mathrm{~b})(2)$ 's nondiscrimination requirement, but has not explained how satisfaction (or nonsatisfaction) of that requirement is to be determined - presumably because, in each such case, it was obvious that the benefits were available to all (or nearly all) of the employer's non-highly compensated employees. See, e.g., I.R.S. Priv. Ltr. Rul. 2003-39-017 (June 17, 2003) (under program established by law firm, benefits available to "all non-lawyer employees"); I.R.S. Priv. Ltr. Rul. 2003-37-004 (June 10, 2003) (program benefits available to "all regularly employed full and part-time employees"); I.R.S. Priv. Ltr. Rul. 2002-45-042 (Aug. 6, 2002) (same); I.R.S. Priv. Ltr. Rul. 94-18-010 (Feb. 1, 1994) (same). The only possible exception is a private letter ruling in which all employees eligible under the program in question were covered by a collective bargaining agreement with the employer. See infra note 143.

${ }^{111}$ Notwithstanding the relative scarcity of authorities on point, it is nevertheless significant that the IRS has never stated that Regulation section 1.410(b)-4, discussed immediately below, does not establish the test for determining whether a given $\$ 127$ program is discriminatory in favor of the employer's highly compensated employees. Indeed, the IRS plainly knows how to announce when it believes that those regulations do not apply. For example, §117(d)(3) sets forth a nondiscrimination requirement for qualified tuition reductions that is similar to $\S 127(\mathrm{~b})(2)$ 's nondiscrimination rule, and the IRS initially determined that Regulation section 1.410(b)-4 established the test for determining whether the $\S 117(\mathrm{~d})(3)$ requirement is met in any particular case. More recently, however, the IRS has changed its position and has announced that Regulation section 1.410(b)-4 does not pertain to the construction or application of $\S 117(\mathrm{~d})(3)$ "because there is no specific language in $\S 117(\mathrm{~d})$ mandating that the same coverage test[s] applicable under $\S 410$ are also applicable under $\S 117$ (d).” I.R.S. Priv. Ltr. Rul. 201516-030 (Jan. 9, 2015); see also I.R.S. Priv. Ltr. Rul. 2010-29-003 (Apr. 15, 2010) (same). In contrast, as discussed below, Treasury regulations under $\S 127$ expressly require that $\S 127(\mathrm{~b})(2)$ 's nondiscrimination rule be applied under the same standard as the nondiscrimination standard under $\S 410(\mathrm{~b})$. Accordingly, on at least one occasion, the IRS has acknowledged - albeit imprecisely - the relevance of the $\S 410$ (b) standard to the analysis of whether a $\$ 127$ program is discriminatory. See I.R.S. Priv. Ltr. Rul. 94-18-010 (Feb. 1, 1994) ("Although the written plan satisfies the requirements of section 127(b)(2) and section 1.127-2(e) no opinion is expressed upon whether the plan in operation satisfies the requirements of section 410(b).") (emphasis added).

${ }^{112}$ Treas. Reg. § 1.127-2(e)(1) (1983).

Pitt Tax Review | ISSN 1932-1821 (print) 1932-1996 (online)

DOI 10.5195/taxreview.2017.68 | http://taxreview.law.pitt.edu 
the Treasury Department promulgated that regulation in $1983,{ }^{113}$ $\S 410$ (b)(1)(B) - which pertains to minimum participation requirements for qualified pension, profit-sharing, and stock bonus plans-provided that a trust forming part of such a plan would qualify under $\S 401$ (a) if the trust benefitted employees within a classification that did not discriminate in favor of highly compensated employees. ${ }^{114}$ Thus, $\S 410(\mathrm{~b})(1)(\mathrm{B})$, as it then existed, contained essentially the same nondiscrimination standard as $\S 127(\mathrm{~b})(2) .{ }^{115}$ Section 410(b) was substantially amended in 1986 as part of the Tax Reform Act of $1986,{ }^{116}$ but the amended version still includes the same nondiscriminatory-classification requirement in what is now $\S 410(\mathrm{~b})(2)(\mathrm{A})(\mathrm{i}){ }^{117}$ Thus, while the cross-reference to $\S 410(\mathrm{~b})(1)(\mathrm{B})$ in Regulation section 1.127-2(e)(1) may be outdated, the substantive provision to which the regulation refers continues to exist.

During the first few years after Regulation section 1.127-2(e)(1) became effective, the IRS interpreted the $\S 410$ (b) standard as simply requiring a classification not to cover "primarily, employees in whose favor discrimination is prohibited." ${ }^{118}$ Based on that reading of the regulation, the IRS deemed an eligible-employee classification within an educational

\footnotetext{
${ }^{113}$ The final version of Treasury Regulation section 1.127-2(e)(1) was originally published in July 1983. See T.D. $7898,1983-2$ C.B. 34.

${ }^{114}$ The 1983 version of $\S 410$ (b)(1)(B) provided that such qualification would appertain if the trust benefitted "such employees as qualify under a classification set up by the employer and found by the Secretary not to be discriminatory in favor of employees who are officers, shareholders, or highly compensated." I.R.C. § 410(b)(1)(B) (1983) (later amended in 1986) (emphasis added).

${ }^{115}$ Compare I.R.C. § 410(b)(1)(B) (1983), with id. § 127(b)(2) (2016). For the relevant language of the former provision, see supra note 114. For the relevant language of the latter provision, see supra note 104.

116 Tax Reform Act of 1986, Pub. L. No. 99-514, § 1112(a), 100 Stat. 2085, 2440-44.

117 Since 1986, § 410(b)'s prohibition of employee classifications that discriminate in favor of highly compensated employees has been contained in $\S 410(\mathrm{~b})(2)(\mathrm{A})$, which provides that a plan meets the requirements of $\S 410$ (b) if:
}

(i) the plan benefits such employees as qualify under a classification set up by the employer and found by the Secretary not to be discriminatory in favor of highly compensated employees, and (ii) the average benefit percentage for employees who are not highly compensated employees is at least 70 percent of the average benefit percentage for highly compensated employees.

I.R.C. $\S 410(\mathrm{~b})(2)(\mathrm{A})(\mathrm{i})$, (ii) (emphasis added).

${ }^{118}$ I.R.S. Priv. Ltr. Rul. 87-16-061 (Jan. 21, 1987) (emphasis added).

Pitt Tax Review | ISSN 1932-1821 (print) 1932-1996 (online) DOI 10.5195/taxreview.2017.68 | http://taxreview.law.pitt.edu 
assistance program to pass muster under $\S 127(b)(2)$ simply if the majority of the covered employees were not highly compensated. ${ }^{119}$ Several years later, however, the Treasury Department promulgated detailed regulations that include a specific numerical formula for determining whether an employee classification discriminates in favor of highly compensated employees within the standard of $\S 410(\mathrm{~b}) .{ }^{120}$

Regulation section 1.410-4, adopted in 1991, ${ }^{121}$ establishes a two-part nondiscriminatory-classification test. The first part of the test, in Regulation section 1.410(b)-4(b), requires any classification of employees who are eligible to benefit under a plan to be "reasonable" and to be established under "objective business criteria." 122 Under this rule, eligible-employee classifications are reasonable if they are based on "specified job categories, nature of compensation (i.e., salaried or hourly), geographic location, [or] similar bona fide business criteria." ${ }^{123}$ For example, in a 1990 private letter ruling, the IRS applied the then-Proposed Regulation section 1.410(b)-4 to determine whether a university's plan for providing undergraduate tuition reductions to its officers, faculty, and senior administrators violated $\S 117(\mathrm{~d})(3)$ 's nondiscrimination requirement for qualified tuition reductions. ${ }^{124}$ The "classification" of eligible employees in that case

\footnotetext{
${ }^{119}$ In applying Regulation section 1.127-2(e)(1) to determine whether an employee classification under a university's $\S 127$ plan discriminated in favor of highly compensated employees within the standard of $\S 410$ (b), the IRS found that the plan in question "cover[ed] nonacademic employees only[,] and since the majority of such employees are not highly compensated... [the plan] satisfie[d] the requirements of section 127(b)(2) of the Code.” I.R.S. Priv. Ltr. Rul. 87-16-061 (Jan. 21, 1987).

${ }^{120}$ See Treas. Reg. § 1.410(b)-4 (as amended in 1992).

${ }^{121}$ The final version of Treasury Regulation section 1.410 (b)-4 was originally published in September 1991. T.D. 8363, 1991-2 C.B. 287; see also Minimum Coverage Requirements, 57 Fed. Reg. 10,953, 10,954 (Mar. 31, 1992) (correcting certain typographical errors in original regulations). The regulations pertain to the current iteration of the nondiscriminatory-classification rule in $\S 410(\mathrm{~b})(2)(\mathrm{A})(\mathrm{i})$.

${ }^{122}$ Treas. Reg. § 1.410(b)-4(b) (as amended in 1992).

${ }^{123} \mathrm{Id}$.

${ }^{124}$ I.R.S. Priv. Ltr. Rul. 90-41-085 (July 19, 1990). Under $§ 117(d)(3)$, a highly compensated employee of an educational organization may exclude a qualified tuition reduction from her gross income under $\S 117(\mathrm{~d})(1)$ "only if such reduction is available on substantially the same terms to each member of a group of employees which is defined under a reasonable classification set up by the employer which does not discriminate in favor of highly compensated employees." The §117(d)(3) nondiscrimination requirement for qualified tuition plans is, in substance, essentially similar to the $\$ 127(\mathrm{~b})(2)$ nondiscrimination requirement for employer assistance programs. See Dodge, supra note 3, at 722 (discussing "the nondiscrimination rule under $\S 127$, which is only slightly different than that under
}

Pitt Tax Review | ISSN 1932-1821 (print) 1932-1996 (online) DOI 10.5195/taxreview.2017.68 | http://taxreview.law.pitt.edu 
consisted (exclusively) of the school's "officers, faculty, and senior administrative staff." The IRS found such classification to be reasonable because, under the test in Proposed Regulation section 1.410(b)-4(b), considerations such as seniority and job description were appropriate criteria for eligibility. ${ }^{125}$

In contrast, under the test in Regulation section 1.410(b)-4(b), "[a]n enumeration of employees by name or other specific criteria having substantially the same effect as an enumeration by name is not considered [to be] a reasonable classification." ${ }^{26}$ Thus, for example, if a university were to adopt a policy of awarding graduate tuition reductions only to certain faculty members on an ad-hoc or case-by-case basis, ${ }^{127}$ such policy would likely not pass muster under $\S 127(b)(2)$, even if it were documented in a written plan. In such a case, the particular individuals to whom the tuition reductions were offered would presumably not constitute a reasonable classification of employees eligible for the benefit.

Yet, while the reasonableness of a plan's eligibility classifications is necessary, it is not sufficient. Under the second part of the nondiscriminatoryclassification test, in Regulation section 1.410(b)-4(c), whether a classification of eligible employees is nondiscriminatory also depends on the percentage of an employer's non-highly compensated employees who are included within the classification, relative to the percentage of the employer's highly compensated employees who are so included. ${ }^{128} \mathrm{~A}$ classification automatically satisfies this part of the test if the ratio of (1) the percentage of the employer's non-highly compensated employees who are eligible to benefit under the plan to (2) the percentage of the employer's highly compensated employees who are eligible to benefit under the plan-

$\S 117(\mathrm{~d})$ )'). In subsequent cases, the IRS has instead taken the position that Regulation section 1.410(b)-4 does not determine the nondiscrimination test under $\S 117(\mathrm{~d})(3)$ because - in contrast to the aforementioned regulation under $\S 127(\mathrm{~b})(2)$ - nothing states that $\S 117(\mathrm{~d})(3)$ should apply the same nondiscriminatory classification standard as $\S 410(\mathrm{~b})$. See supra note 111.

${ }^{125}$ I.R.S. Priv. Ltr. Rul. 90-41-085 (July 19, 1990).

${ }^{126}$ Treas. Reg. § 1.410(b)-4(b).

${ }^{127}$ For hypothetical examples of such ad-hoc or case-by-case approaches, see supra notes 101-02 and accompanying text.

${ }^{128}$ Treas. Reg. § 1.410(b)-4(c).

Pitt Tax Review | ISSN 1932-1821 (print) 1932-1996 (online) DOI 10.5195/taxreview.2017.68 | http://taxreview.law.pitt.edu 
defined as the plan's "ratio percentage"129 — equals or exceeds the employer's "safe harbor percentage." ${ }^{130}$ On the other hand, a classification automatically fails this part of the test if the plan's ratio percentage is less than the employer's "unsafe harbor percentage." "131 If a plan's ratio percentage is less than the employer's safe harbor percentage but equal to or greater than the employer's unsafe harbor percentage, then whether an eligible-employee classification is nondiscriminatory is determined on the basis of the particular facts and circumstances of the case. ${ }^{132}$

Consider, for instance, a university with an educational assistance program that offered benefits only to the school's full-time faculty, or only to the school's full-time faculty and senior administrators. As noted above, the program's classification of eligible employees would be reasonable under the Regulation section 1.410(b)-4(b) test. ${ }^{133}$ Nevertheless, the program's

\footnotetext{
${ }^{129} I d$. $\S 1.410$ (b)-9 (as amended in 2004).
}

${ }^{130} I d$. $\S 1.410(\mathrm{~b})-4(\mathrm{c})(2)$. An employer's "safe harbor percentage" is generally $50 \%$, but is reduced by three-fourths of one percent for each percentage point by which the employer's percentage of nonhighly compensated employees exceeds $60 \%$. Id. $\S 1.410$ (b)-4(c)(4)(i). So, if the percentage of an employer's employees who are not highly compensated is $60 \%$ or less, the safe harbor percentage is $50 \%$. But, for example, if $61 \%$ of the employer's employees are not highly compensated, the safe harbor percentage is $49.25 \%$. Id. $\S 1.410$ (b)-4(c)(4)(iv). The regulations include a table that sets forth the applicable safe harbor percentage corresponding to any given percentage concentration of an employer's non-highly compensated employees. See id.

${ }^{131} I d$. $\S 1.410$ (b)-4(c)(3)(i)(A). An employer's "unsafe harbor percentage" is generally $40 \%$, but is reduced by three-fourths of one percent for each percentage point by which the employer's percentage of non-highly compensated employees exceeds $60 \%$ - provided, that the unsafe harbor percentage is never less than $20 \%$. Id. $\$ 1.410$ (b)-4(c)(4)(ii). So, if the percentage of an employer's employees who are not highly compensated is $60 \%$ or less, the unsafe harbor percentage is $40 \%$. But, if $61 \%$ of the employer's employees are not highly compensated, the safe harbor percentage is $39.25 \%$, and if $89 \%$ or more of the employer's employees are not highly compensated, the safe harbor percentage is $20 \%$. Id. $\S 1.410$ (b)4(c)(4)(iv). The regulations include a table that sets forth the applicable unsafe harbor percentage corresponding to any given percentage concentration of an employer's non-highly compensated employees. See id.

${ }^{132} I d$. $\S 1.410$ (b)-4(c)(3). For purposes of this inquiry, relevant facts and circumstances include, inter alia, (1) "[t]he underlying business reason for the classification," (2) "[t]he percentage of the employer's employees benefiting under the plan," (3) "[w]hether the number of employees benefiting under the plan in each salary range is representative of the number of employees in each salary range of the employer's workforce," and (4) "[t]he difference between the plan's ratio percentage and the employer's safe harbor percentage." Id. § 1.410(b)-4(c)(3)(ii).

${ }^{133}$ See supra text accompanying notes $124-25$.

Pitt Tax Review | ISSN 1932-1821 (print) 1932-1996 (online) DOI 10.5195/taxreview.2017.68 | http://taxreview.law.pitt.edu 
eligible-employee classification would likely be discriminatory under the Regulation section 1.410(b)-4(c) test. ${ }^{134}$

At a typical doctoral-granting research institution, there are two categories of employees whose compensation levels render them "highly compensated employees" under $\S 414(q)$-full professors and executives or senior-level administrators. ${ }^{135}$ On average, approximately $21 \%$ of a research university's employees are full-time faculty ${ }^{136}$ and, of those, approximately $34 \%$ are full professors. ${ }^{137}$ At the same time, on average, approximately $7 \%$

${ }^{134}$ Cf. I.R.S. Priv. Ltr. Rul. 90-41-085 (July 19, 1990) (under then-proposed version of Regulation section 1.410(b)-4(c), tuition reduction program available only to university's faculty, officers, and senior administrative staff had classification with ratio percentage lower than applicable unsafe harbor percentage and was therefore discriminatory under $\S 117(\mathrm{~d})(3)$ ); Dodge, supra note 3, at 722 (noting that a tuition reduction "program limited to faculty members and administrators ... would probably fail the discrimination test" under $\S 117(\mathrm{~d})(3)$, "which is only slightly different than" the nondiscrimination test for educational assistance programs under $§ 127(\mathrm{~b})(2))$.

${ }^{135}$ According to a salary survey conducted by the College and University Professional Association for Human Resources (CUPA-HR), the average salary of a full professor at a research university for academic year 2016-2017 (counting professors in all academic disciplines) was \$120,498. Tenured/Tenure-Track Faculty Salaries, HIGHER ED JOBS, https://www.higheredjobs.com/salary/ salaryDisplay.cfm?SurveyID=39 (last visited Jan. 3, 2018). According to another CUPA-HR salary survey, the median salaries for the vast majority of executive and senior-level administrative positions at research universities during academic year 2016-2017 were more than $\$ 120,000$ (the current threshold compensation level for designation as a "highly compensated employee" under $\S 414(\mathrm{q})(1)(\mathrm{B})(\mathrm{i})$ ). Administrators in Higher Education Salary Report, HIGHER ED JOBS, https://www.higheredjobs.com/ salary/salaryDisplay.cfm?SurveyID=38 (last visited Jan. 3, 2018). According to CUPA-HR's 2016-2017 salary surveys, other broad categories of a research university's employees-including mid-level administrators and non-exempt staff-all had average or median salaries below $\$ 120,000$ for academic year 2016-2017. CUPA-HR Salary Surveys, 2016-17, HIGHER ED JOBS, https://www.higheredjobs.com/ salary/ (last visited Jan. 3, 2018) (providing links to CUPA-HR salary surveys for university executives, mid-level administrators, nonexempt staff, and tenured or tenure-track faculty).

${ }^{136}$ As of 2012, on average, approximately $20 \%$ of the employees at public research universities, and approximately $22 \%$ of the employees at private research universities, were full-time faculty members. Donna M. Desrochers \& Rita Kirshstein, Labor Intensive or Labor Expensive? Changing Staffing and Compensation Patterns in Higher Education, DelTa Cost PROJECT AT AMERICAN INSTITUTES FOR RESEARCH 8 (Feb. 2014), http://www.deltacostproject.org/sites/default/files/products/DeltaCostAIR _ Staffing_Brief_2_3_14.pdf.

${ }^{137}$ According to a senior researcher at the American Association of University Professors, full professors comprise approximately $10 \%$ of all college faculty. At the same time, full-time, tenure-track faculty members generally (including full, associate, and assistant professors) comprise approximately $29.6 \%$ of all college faculty. See Brian Tumulty, Half of New York College Professors Make Less Than $\$ 100,000$, POUGHKEEPSIE J. (Apr. 13, 2015), http://www.poughkeepsiejournal.com/story/news/ local/2015/04/13/half-new-york-college-professors-make-less/25744209. Based on those statistics, approximately $33.78 \%(10 \% \div 29.6 \%)$ of full-time faculty are full professors.

Pitt Tax Review | ISSN 1932-1821 (print) 1932-1996 (online)

DOI 10.5195/taxreview.2017.68 | http://taxreview.law.pitt.edu 
of a research university's employees are executive, administrative, or managerial personnel. ${ }^{138}$

Imagine a hypothetical research university with a workforce, the composition of which matches those average employee statistics. Such a university would have an unsafe harbor percentage of approximately $20.50 \%,{ }^{139}$ and an educational assistance program offered only to its professors and senior administrators would have a ratio percentage of approximately $16 \% .{ }^{140}$ Thus, under the Regulation section $1.410(\mathrm{~b})-4(\mathrm{c})$ test, the eligible-employee classification of such program would automatically be discriminatory in favor of highly compensated employees.

In order to come within the test's safe harbor, the hypothetical university's educational assistance program would have to have a ratio percentage of at least $30.50 \% .{ }^{141}$ To attain that percentage, the university

${ }^{138}$ As of 2012, on average, approximately four percent of the employees at public research universities, and approximately ten percent of the employees at private research universities, were executive, administrative, and managerial personnel. See Desrochers \& Kirshstein, supra note 136, at 8.

${ }^{139}$ In this example, if approximately $21 \%$ of the hypothetical university's employees are full-time faculty, and if approximately $34 \%$ of such full-time faculty are full professors, then approximately $7 \%$ $(21 \% \times 34 \%)$ of the university's employees are full-time professors. If the university's only highly compensated employees are full professors and executives or senior-level administrators, and if executives and senior administrators comprise $7 \%$ of the university's employees, then a total of $14 \%$ of the university's employees are highly compensated (under $\S 414(\mathrm{q})(1)(\mathrm{B})(\mathrm{i})$ ) and the remaining $86 \%$ of employees are non-highly compensated. For an employer whose non-highly compensated employee concentration percentage is $86 \%$, the unsafe harbor percentage is $20.50 \%$. Treas. Reg. $\S 1.410$ (b)4(c)(4)(iv) (as amended in 1992) (table setting forth the applicable unsafe harbor percentages corresponding to given percentage concentrations of an employer's non-highly compensated employees).

${ }^{140}$ The program's ratio percentage equals (1) the percentage of the hypothetical university's nonhighly compensated employees who can benefit under the program, divided by (2) the percentage of the university's highly compensated employees who can benefit under the program. Treas. Reg. $\S 1.410$ (b)9 (as amended in 1992). In this example, the only non-highly compensated employees who are eligible for benefits under the program are full-time faculty other than full professors. If full professors comprise approximately $34 \%$ of full-time faculty, then the remaining $66 \%$ of full-time faculty are non-highly compensated employees. If $21 \%$ of the university's employees are full-time faculty, then approximately $14 \%(21 \%$ x $66 \%)$ of the university's employees are non-highly compensated employees who can benefit under the program. As a result, the percentage of the university's non-highly compensated employees who can benefit under the plan is approximately $16 \%(14 \% \div 86 \%)$. At the same time, literally all$100 \%$ - of the university's highly compensated employees are eligible for benefits under the program. Thus, the program's ratio percentage is $16 \%(16 \% \div 100 \%)$.

${ }^{141}$ In this example, $86 \%$ of the hypothetical university's employees are non-highly compensated. See supra note 139. For an employer whose non-highly compensated employee concentration percentage is $86 \%$, the safe harbor percentage is $30.5 \%$. Treas. Reg. $\$ 1.410$ (b)-4(c)(4)(iv) (table setting forth the

Pitt Tax Review | ISSN 1932-1821 (print) 1932-1996 (online)

DOI 10.5195/taxreview.2017.68 | http://taxreview.law.pitt.edu 
would have to offer the program to significantly more of its non-highly compensated employees - such as, perhaps, mid-level administrators or nonexempt staff. ${ }^{142}$ Of course, the figures in this example do not necessarily reflect the exact ratio percentage or safe harbor percentage that would apply in the case of any particular actual university or educational assistance plan. The example demonstrates, however, that - in general ${ }^{143}$ - a university's educational assistance program is likely to be discriminatory under Regulation section 1.410(b)-4(c) unless it is offered to a broad cross-section of the school's staff, as well to the school's faculty and senior

applicable safe harbor percentages corresponding to given percentage concentrations of an employer's non-highly compensated employees).

${ }^{142}$ To attain a $30.5 \%$ ratio percentage, the program would have to make benefits available to approximately $26.23 \%((30.5 \%$ x $86 \%) \div 100 \%)$ of the hypothetical university's non-highly compensated employees. To achieve such a result, the university would have to add categories of eligible employees under the program that are both (1) reasonable classifications under the Regulation section 1.410(b)-4(b) test and (2) comprised of non-highly compensated employees. As noted above, see supra note 135, midlevel administrators and nonexempt staff at research universities had median salaries for academic year 2016-2017 below the current compensation threshold for highly compensated employees under $\S 414(q)(1)(B)(i)$. At the same time, "mid-level administrators" and "nonexempt staff" would likely constitute "reasonable" classifications "established under objective business criteria [to] identify [categories] of employees who benefit under the [program]." Treas. Reg. § 1.410(b)-4(b).

${ }^{143}$ Interestingly, an exception to this general rule may apply in the case of an educational assistance program offered only to faculty or administrators, if the university's employees are covered by a collective bargaining agreement with the school. Section 127(b)(2) provides that, for purposes of determining whether an educational assistance program meets the nondiscrimination requirement:

there shall be excluded from consideration employees not included in the program who are included in a unit of employees covered by ... a collective bargaining agreement between employee representatives and one or more employers, if there is evidence that educational assistance benefits were the subject of good faith bargaining between such employee representatives and such employer or employers.

I.R.C. $\S 127(\mathrm{~b})(2)$. The foregoing language seems to instruct that, when calculating the respective percentages of highly compensated and non-highly compensated employees who are eligible for benefits under a $\$ 127$ program, one should not count ineligible employees who are covered under a collective bargaining agreement with the employer. See Dodge, supra note 3, at 737 n.229 ("Under section 127 there can be excluded any group of employees subject to a collective bargaining agreement if there was goodfaith bargaining as to educational benefits."). However, in at least one case, the IRS appears to have construed that language more broadly — and to have determined that a $\S 127$ program was automatically nondiscriminatory, simply because all of the eligible employees were covered by a collective bargaining agreement. In a 2006 private letter ruling, the IRS summarily concluded that, where the only employees eligible to participate in an educational assistance program were covered by a collective bargaining agreement with the employer, and where the program itself was established pursuant to such agreement, the program met the nondiscrimination requirement of $\S 127$ (b)(2). I.R.S. Priv. Ltr. Rul. 2006-24-059 (Feb. 24, 2006).

Pitt Tax Review | ISSN 1932-1821 (print) 1932-1996 (online)

DOI 10.5195/taxreview.2017.68 | http://taxreview.law.pitt.edu 
administration. ${ }^{144}$

In sum, if a university provides graduate tuition reductions to a faculty member pursuant to a written plan that satisfies all requirements of $\S 127(\mathrm{~b})$, the first $\$ 5,250$ of the tuition reduction provided in a given calendar year can be excluded from the faculty member's gross income for the corresponding taxable year under $\S 127(\mathrm{a})$. Given the cost of graduate tuition at most universities, $\S 127$ can provide, at most, a partial exclusion of such a tuition reduction. Moreover, if a university awards a graduate tuition reduction to a faculty member without having adopted a written plan for such benefits, or if it makes such an award pursuant to a written plan that fails to meet one or more of $\S 127(\mathrm{~b})$ 's requirements - including, among others, the nondiscrimination requirement in $\S 127(\mathrm{~b})(2)$ - no part of the tuition reduction will be excludable under $\S 127$ (a).

For faculty members who can claim a partial exclusion under $\S 127$, is there any other exclusion provision that might enable them to exclude the remainder of their graduate tuition reductions? And, for faculty members who cannot exclude any part of their graduate tuition reductions under $\S 127$, is there any other exclusion provision to which they can turn? As luck and the Code would have it, there is one more place to look.

\section{SECTION 132 PROVIDES AN EXCLUSION FOR GRADUATE TUITION REDUCTIONS THAT ARE "WORKING CONDITION FRINGES"}

A graduate tuition reduction provided by a university to one of its employees - including a faculty member - is potentially excludable under $\S 132(\mathrm{a})(3)$ if it meets $\S 132(\mathrm{~d})$ 's definition of a "working condition

\footnotetext{
${ }^{144}$ For the reasons described above, the authors believe that, despite the dearth of definitive authority on point, in any case where the facts indicate possible discrimination, the IRS and the courts should and would apply the Regulation section 1.410(b)-4 test to determine whether a $\S 127$ plan does in fact discriminate in favor of highly compensated employees. See supra notes 110-11 and accompanying text; see also supra text accompanying notes 112-20. Nevertheless, even if the IRS or a court were instead to revert to the earlier test under Regulation section 1.127-2(e)(1) - in which a classification was simply prohibited from primarily covering highly compensated employees - an educational assistance program covering only a university's faculty and senior administrators would still fail. See supra text accompanying notes 118-19 (discussing early "primarily" test). Given that such a program would cover virtually all of the university's highly compensated employees and only a small percentage of the university's non-highly compensated employees, there could be no argument that the majority of eligible employees under the program were non-highly compensated.
}

Pitt Tax Review | ISSN 1932-1821 (print) 1932-1996 (online) DOI 10.5195/taxreview.2017.68 | http://taxreview.law.pitt.edu 
fringe." ${ }^{145}$ Under current IRS policy, if the first $\$ 5,250$ of a graduate tuition reduction is excludable under $\S 127$ and if the tuition reduction constitutes a working condition fringe, then any portion of the reduction in excess of $\$ 5,250$ is excludable under $\S 132(\mathrm{a})(3) .{ }^{146}$ But, if the first $\$ 5,250$ is not excludable under $\S 127$, the IRS will not allow a graduate tuition reduction to be excluded as a working condition fringe. ${ }^{147}$

As discussed in Part V below, the authors believe that the IRS is wrong to condition the availability of a $\S 132$ (a)(3) exclusion on the applicability of $\S 127$. As explained in Part V, a taxpayer would have ample grounds on which to challenge the IRS's position and to argue that the working condition fringe exclusion can apply to a graduate tuition reduction even when $\S 127$ does not apply to such benefit. Before turning to those arguments, however, let us examine how the $\S 132(\mathrm{a})(3)$ exclusion works and what is necessary for a graduate tuition reduction to come within the "working condition fringe" definition under $\S 132(d)$.

\section{A. Section 132(a)(3) Excludes Educational Benefits that Constitute “Working Condition Fringes" under § 132(d)}

Section 61(a)(1) states that fringe benefits are a form of compensation for services and, as such, are generally includible in the recipient's gross income. ${ }^{148}$ Nevertheless, $\S 132$ sets forth exclusions from gross income for eight specific categories of fringe benefits that employers routinely provide to their employees. ${ }^{149}$ On initial reading, graduate tuition benefits that a university furnishes to its faculty members might appear to come within three

${ }^{145}$ I.R.C. $\S 132(\mathrm{a})(3),(\mathrm{d})$.

${ }^{146}$ I.R.S. Non-Docketed Serv. Adv. Review 2010-39-01F (July 27, 2010).

${ }^{147} I d$.; I.R.S. Field Serv. Adv. 2002-31-016 (Mar. 13, 2002).

${ }^{148}$ I.R.C. § 61(a)(1) (setting forth that, "[e]xcept as otherwise provided in [Subtitle A of the Code], gross income means all income from whatever source derived, including (but not limited to)... compensation for services, including fees, commissions, fringe benefits, and similar items" (emphasis added)).

${ }^{149}$ The eight excluded categories include "any fringe benefit which qualifies as a ... (1) noadditional-cost service, (2) qualified employee discount, (3) working condition fringe, (4) de minimis fringe, (5) qualified transportation fringe, (6) qualified moving expense reimbursement, (7) qualified retirement planning services, or (8) qualified military base realignment and closure fringe." Id. $\S 132(a)(1)$.

Pitt Tax Review | ISSN 1932-1821 (print) 1932-1996 (online) DOI 10.5195/taxreview.2017.68 | http://taxreview.law.pitt.edu 
of those fringe-benefit categories - no-additional-cost services, ${ }^{150}$ qualified employee discounts, ${ }^{151}$ and working condition fringes. ${ }^{152}$ On further review, however, the Code makes clear that, in the case of any employer-provided

\footnotetext{
${ }^{150}$ A "no-additional-cost service" is
}

any service provided by an employer to an employee for use by such employee if... (1) such service is offered for sale to customers in the ordinary course of the line of business of the employer in which the employee is performing services, and (2) the employer incurs no substantial additional cost (including forgone revenue) in providing such service to the employee ....

Id. $\S 132$ (b). A university's award of a graduate tuition reduction to a faculty member could be characterized as an employer's provision to an employee of a service that it offers for sale to its "customers." And, if the school awards the tuition reduction for a graduate course in which there would otherwise be an empty seat if the faculty member did not enroll, it may well provide such service at no additional cost. See Dodge, supra note 3, at 744-45 (noting that employee tuition reductions are similar to no-additional-cost services). Nonetheless, as discussed below, §132(j)(8) prohibits excluding employer-provided educational benefits under any $\S 132$ category other than working condition fringes. And, even if it were not for that rule, there are a number of circumstances in which faculty graduate tuition reductions might not come within the definition of a "no-additional-cost service" in the first place. For example, if a university declines to admit another prospective student in order to make a space in the course for the faculty member, then it arguably forgoes revenue by providing the service. See id. at 743 ("The excess-capacity threshold test [for excluding a fringe benefit as a no-additional-cost service] would seem to rule out... those employees enrolled in a degree program in which admissions are highly selective....”). In addition, a faculty member's graduate tuition reduction might fall outside the definition if the related "courses of instruction emphasiz[e] seminars, tutorials, and papers[,]" given that "the services provided to the employees must not be labor-intensive" if they are to qualify as "noadditional-cost." Id. (citing Treas. Reg. § 1.132-2(a)(5)).

${ }^{151}$ A "qualified employee discount" includes "any employee discount with respect to qualified ... . services to the extent such discount does not exceed . . 20 percent of the price at which the services are being offered by the employer to customers." I.R.C. $\$ 132(\mathrm{c})(1)(B)$. "Qualified services," in turn, are "services which are offered for sale to customers in the ordinary course of the line of business of the employer in which the employee is [performing] services." Id. $\S 132$ (c)(4) (In addition to such discounts on services, qualified employee discounts also include discounts on certain "qualified property."). A faculty graduate tuition reduction in an amount of up to twenty percent of the tuition charged to paying students could conceivably come within the scope of the "qualified employee discount" definition. See Dodge, supra note 3, at 744, 745 (noting that employee tuition reductions are similar to qualified employee discounts). However, applying the definition "to educational discounts would be problematic, given the fact that scholarships offered to nonemployees create a differential price structure." Id. at 742 . In short, the fact that different tuition amounts are charged to different students would make it difficult to identify "the price at which the services are being offered by the employer to customers" for purposes of determining what constitutes a twenty percent discount. See id. at 742-43 (discussing same). Moreover, because of the twenty-percent-discount limitation on the exclusion amount, the qualified employee discount exclusion would be presumably less attractive than exclusions under other prongs of $\S 132$, given that the result would often be only a partial exclusion of the tuition reduction. In any event, like the noadditional-cost service exclusion, the qualified employee discount exclusion is ultimately unavailable for faculty graduate tuition reductions, given the rule in $\S 132(\mathrm{j})(8)$ against excluding employer-provided educational benefits under any $\S 132$ category other than working condition fringes. See infra note 154 .

Pitt Tax Review | ISSN 1932-1821 (print) 1932-1996 (online) DOI 10.5195/taxreview.2017.68 | http://taxreview.law.pitt.edu 
education benefits, the only prong of $\S 132$ that potentially applies is the working condition fringe exclusion under $\S 132(a)(3)$. Under $\S 132(\mathrm{j})(8)$, "[a]mounts paid or expenses incurred by the employer for education or training provided to the employee which are not excludable from gross income under section 127 shall be excluded from gross income under this section [132] if (and only if) such amounts or expenses are a working condition fringe." 153 On its face, $\S 132(\mathrm{j})(8)$ permits the exclusion of any educational fringe benefit that meets the definition of a working condition fringe but that would not qualify for exclusion under $\S 127$ - either because the amount of the benefit exceeds $\S 127$ 's $\$ 5,250$ annual cap or because the employer did not provide the benefit under a plan that meets $\S 127$ 's requirements. ${ }^{154}$

To qualify for the working condition fringe exclusion, an employerprovided fringe benefit must be of a sort that, if the employee paid for the benefit herself, "such payment would be allowable as a deduction under [§] 162" as an ordinary and necessary trade or business expense. ${ }^{155}$ If an employee incurs expenses related to her employment, those costs qualify as deductible trade or business expenses under $\S 162 .{ }^{156}$ If her employer

152 " [T] $[$ he term 'working condition fringe' means any property or services provided to an employee of the employer to the extent that, if the employee paid for such property or services, such payment would be allowable as a deduction under section 162 or 167." I.R.C. § 132(d). The possible application of the working condition fringe exclusion to employer-provided education benefits, including graduate tuition reductions for university faculty, is discussed in detail below.

${ }^{153}$ I.R.C. $§ 132(\mathrm{j})(8)$.

${ }^{154}$ See Fenton, supra note 78, at 52-53 (“[S]ection 132(j)(8) allows for the exclusion of [education benefit] payments in excess of the $\$ 5,250$ maximum [under section 127] if they qualify as a working condition fringe benefit . . . . Alternatively, when [an employer] doesn't fund section 127 programs during a particular year, it may still use section 132(d)."); see also Dodge, supra note 3, at 721 ("Failure to qualify under section 127 does not automatically preclude exclusion under ... section 132(d) (working-condition fringes)...."). For a discussion of the legislative intent underlying §132(j)(8), see infra text accompanying notes 260-61 and 289. For an explanation of how the provision's legislative history confirms that $\$ 132(\mathrm{j})(8)$ permits the working condition fringe exclusion even if $\$ 127$ does not exclude the first $\$ 5,250$ of the benefit in question, see infra text accompanying notes 293-96.

${ }^{155}$ I.R.C. $\S 132(d)$.

${ }^{156}$ As with all other trade or business deductions, an employee expense must be an "ordinary and necessary expense[] paid or incurred [by the taxpayer] during the taxable year in carrying on [a] trade or business" to be deductible under $\S 162$ (a). The particular trade or business to which such an expense would relate is "the trade or business of performing services as an employee." See, e.g., id. § 62(a)(1) (referring to same); see also John A. Miller \& Robert Pikowsky, Taxation and the Sabbatical: Doctrine, Planning, and Policy, 63 TAX LAW. 375, 379 (2010) ("A person does not need to own a business in order

Pitt Tax Review | ISSN 1932-1821 (print) 1932-1996 (online)

DOI 10.5195/taxreview.2017.68 | http://taxreview.law.pitt.edu 
subsequently reimburses her for such expenses, the employee can deduct the amount as an above-the-line deduction in arriving at adjusted gross income. ${ }^{157}$ In contrast, unreimbursed employee expenses are "miscellaneous itemized deductions" under $\S 67(\mathrm{~b}) .^{158}$

The sweeping tax reform law that was enacted at the end of 2017 (commonly referred to as the Tax Cuts and Jobs Act) amends $\S 67$ to suspend taxpayers' ability to claim any miscellaneous itemized deductionsincluding unreimbursed employee expenses - for taxable years beginning after December 31, 2017 and before January 1, 2026. ${ }^{159}$ Nonetheless, that change does not affect the qualification of employment-related expenses as trade or business expenses, which are deductible under $\S 162 .{ }^{160}$ And, as noted above, it is whether a deduction for a particular expense would be available under $\S 162$ - and not the extent to which such a $\S 162$ deduction would then be limited under $\S 67^{161}$ — that determines whether a benefit is a

to incur deductible business expenses. The Tax Court has explained that 'a taxpayer may be in the trade or business of being an employee ...."”) (quoting Hantzis v. Comm'r, 638 F.2d 248, 249 (1st Cir. 1981)).

${ }^{157}$ See I.R.C. $\$ 62(\mathrm{a})(2)(\mathrm{A})$ (providing that reimbursed employee expenses are deductible in computing adjusted gross income).

${ }^{158} I d$. $\S 67(\mathrm{~b})$. Unlike deductions for trade or business expenses generally, deductions for unreimbursed employee expenses are not deducted in arriving at adjusted gross income. See id. $\S 62(a)(1)$ (providing that deductions for expenses "which are attributable to a trade or business carried on by the taxpayer" are deducted in computing adjusted gross income, "if such trade or business does not consist of the performance of services by the taxpayer as an employee" (emphasis added)). Instead, an employee would have to elect to itemize her deductions under $\S 63(\mathrm{e})$ in order to deduct (from adjusted gross income) her unreimbursed employee expenses as "miscellaneous itemized deductions"-if, and to the extent that, the employee would be allowed to claim miscellaneous itemized deductions for the taxable year in question. Id. $\S 67$ (setting forth rules for allowance of such deductions). Unreimbursed employee expenses come within the broad category of miscellaneous itemized deductions under $\S 67(\mathrm{~b})$.

159 See Tax Cuts and Jobs Act, Pub. L. No. 115-97, § 11045, 131 Stat. 2054, 2088 (2017). For taxable years beginning prior to January 1, 2018, §67(a) provides that an individual taxpayer's miscellaneous itemized deductions are "allowed only to the extent that the aggregate of such deductions exceeds 2 percent of [the taxpayer's] adjusted gross income" for the taxable year in question. I.R.C. $\S 67(\mathrm{a})$. The Tax Cuts and Jobs Act adds to the Code a new $\S 67(\mathrm{~g})$, which provides that "[n]otwithstanding [§67(a)], no miscellaneous itemized deduction shall be allowed for any taxable year beginning after December 31, 2017, and before January 1, 2026.” Tax Cuts and Jobs Act § 11045.

${ }^{160}$ For example, reimbursed employee expenses-which are deductible as trade or business expenses under $\S 162$ - continue to be above-the-line deductions in arriving at adjusted gross income for taxable years beginning after December 31, 2017 and before January 1, 2026. See I.R.C. § 62(a)(2)(A).

${ }^{161}$ Even prior to the 2017 Tax Cuts and Jobs Act, $\S 67$ has limited the extent to which the cost of an employment-related benefit would have been deductible by an employee (assuming such cost would

Pitt Tax Review | ISSN 1932-1821 (print) 1932-1996 (online)

DOI 10.5195/taxreview.2017.68 | http://taxreview.law.pitt.edu 
"working condition fringe" under $\S 132(\mathrm{~d})$. Accordingly, the amendment to $\S 67$ in the Tax Cuts and Jobs Act does not appear to suspend or restrict in any way the availability of the working condition fringe exclusion under $\S 132(\mathrm{a})(3) .^{162}$

have constituted a trade or business expense under $\S 162$ ) if the employee had paid the cost herself and had not been reimbursed by her employer. However, such limitations under $\S 67$ have never affected the extent to which such a benefit would be excludable as a working condition fringe. For taxable years beginning before 2018, an unreimbursed employee expense is deductible under $\S 67$ (a) as a "miscellaneous" itemized deduction only to the extent of the excess of (1) the expense amount (together with any other miscellaneous itemized deductions for the year) over (2) two percent of the employee's adjusted gross income. I.R.C. § 67(a). Imagine, for example, that in taxable year 2017 an employee paid $\$ 500$ for subscriptions to work-related publications that she used in the course of her employment. Assume that (1) her employer did not reimburse her for her expense, (2) her adjusted gross income for 2017 was $\$ 40,000$, and (3) the expense of the publications was her only miscellaneous itemized deduction for 2017. The employee would not be able to claim any deduction for the cost of the subscriptions because the amount of her miscellaneous itemized deductions $(\$ 500)$ is less than two percent of her adjusted gross income $(\$ 800)$. Does this mean that, if the employer had instead provided the employee with subscriptions to the publications, the employee would not be able to exclude the $\$ 500$ value of those subscriptions as a working condition fringe? Under the Treasury regulations, the answer is plainly "no." Regulation section 1.132-5(a)(1)(vi) expressly provides that "[t]he limitation of section 67(a) (relating to the two-percent floor on miscellaneous itemized deductions) is not considered when determining the amount of a working condition fringe." Treas. Reg. §1.132-5(a)(1)(vi) (as amended in 2010). Thus, in the example above, the employee would be able to exclude the value of the employer-provided subscriptions as a working condition fringe, notwithstanding that she would not be able to deduct the unreimbursed cost of the subscriptions if she paid the expense herself. The new $\S 67(\mathrm{~g})$ added under the 2017 Tax Cuts and Jobs Act is essentially a modification of $\S 67$ (a) that further limits the extent to which $\S 67$ (a) allows miscellaneous itemized deductions during taxable years beginning after December 31, 2017 and before January 1, 2026. Thus, pursuant to Regulation section 1.132-5(a)(1)(vi), §67(g)'s disallowance of miscellaneous itemized deductions should have no effect on the availability of working condition fringes.

${ }^{162}$ Indeed, any alternative interpretation of the interplay (or lack thereof) between the new $\S 67(\mathrm{~g})$ and the definition of a "working condition fringe" under $\S 132(\mathrm{~d})$ would be unreasonable. As noted above, reimbursed employee expenses obviously continue to be deductible (as above-the-line deductions) pursuant to $\S \S 162$ and 62(a)(2)(A). See supra notes 157 and 160. Thus, if the working condition fringe exclusion were eliminated as a result of $\S 67(\mathrm{~g})$, then an employee would be precluded from excluding the value of a working condition fringe benefit that she received directly from her employer, even though she would be able to deduct the entirety of such amount if she initially paid the cost of the benefit herself and were then reimbursed by her employer - an absurd result. Furthermore, the legislative history of the Tax Cuts and Jobs Act plainly indicates that Congress intended to preserve the working condition fringe exclusion. The original House version of the bill contained what would have been a new $\S 262 \mathrm{~A}$ (a) of the Code, which would have provided that "no deduction shall be allowed with respect to any trade or business of the taxpayer which consists of the performance of services by the taxpayer as an employee." H.R. 1, 115 th Cong. $§ 1312$ (2017) (House engrossed version). That provision would have effectively eliminated employee expenses from the universe of $\S 162$ trade or business expenses. Mindful of the fact that making employee expenses nondeductible under $\S 162$ would have otherwise eviscerated the working condition fringe exclusion, the House also included a $\S 262 \mathrm{~A}(\mathrm{c})$ in its bill, which would have expressly provided for the "continued exclusion of working condition fringe benefits." $I d$. In the final version of the Tax Cuts and Jobs Act, the House's proposed addition of a new $\S 262 \mathrm{~A}$ was replaced with the provision (from the

Pitt Tax Review | ISSN 1932-1821 (print) 1932-1996 (online)

DOI 10.5195/taxreview.2017.68 | http://taxreview.law.pitt.edu 
Thus, whether an employer-provided educational benefit qualifies as a working condition fringe depends on whether such benefit is deductible under $\S 162$ (without regard to $\S 67$ ). Unreimbursed costs that an employee incurs for employment-related education are trade or business expenses under $\S 162$ if the educational expenditures meet certain requirements set forth in Regulation section 1.162-5. ${ }^{163}$ Under those regulations, an employee's educational expense qualifies as deductible under $\S 162$ if (and only if) the education in question either (1) "[m]aintains or improves skills required by the [employee] in his employment" or (2) "[m]eets the express requirements of the ... employer, or the requirements of applicable law or regulations," on which the employee's continued employment is conditioned. ${ }^{164}$ At the same time, to be deductible, the expense cannot be for education that either (1) constitutes the minimum education required for the employee's current position ${ }^{165}$ or (2) qualifies the employee for a new trade or business. ${ }^{166}$ If the cost of an employee's education would meet the

Senate amendment to the House bill) that adds $\S 67(\mathrm{~g})$. See Tax Cuts and Jobs Act, Pub. L. No. 115-97, $\S 11045,131$ Stat. 2054, 2088 (2017). Given that the approach in the final law merely modifies $\S 67-$ and not $\S 162$ itself - there was ultimately no need to include an express clarification that the working condition fringe exclusion continues to exist. (Because the $\S 132(\mathrm{~d})$ definition of a "working condition fringe" is based on deductibility under $\S 162$, amending $\S 67$ does not call the survival of the working condition fringe exclusion into question in the first place.) Nevertheless, the care that the House took to ensure that its approach did not inadvertently eliminate working condition fringes strongly supports the conclusion that Congress did not intend to eliminate the exclusion when suspending the availability of miscellaneous itemized deductions.

${ }^{163}$ Treas. Reg. § 1.162-5 (1967).

${ }^{164} I d$. $\$ 1.162-5$ (a) (1967). These two "affirmative" requirements for deductibility are to distinguish educational expenses that are truly business-related from educational expenses that are merely personal in nature. See Lazar, supra note 67, at 1069. Except to the extent that the Code expressly provides a deduction for a particular expense of that nature, "no deduction [is] allowed for personal, living, or family expenses.” I.R.C. § 262(a).

${ }^{165}$ Treas. Reg. $\S 1.162-5(\mathrm{~b})(2)$.

${ }^{166} I d$. $\S 1.162-5(\mathrm{~b})(3)$. The regulations' two "negative" requirements for deductibility of employment-related educational expenses appear to be intended to distinguish educational costs that are ordinary business expenses (and, thus, deductible under § 162) from educational costs that are more in the nature of a capital expenditure. See Lazar, supra note 67, at 1069-70. Under § 263, capital expenditures generally cannot be deducted in their entirety in the year of the expenditure. I.R.C. § 263(a). Nonetheless, "[c]apital expenditures are depreciable or amortizable over their useful life, provided that a useful life can be estimated with reasonable accuracy." Lazar, supra note 67, at 1069 (citing I.R.C. $\S \S 167,168,195$, 197). In contrast, "[w]here a useful life cannot reasonably be determined, the cost of such capital expenditure may be recovered when the purchased asset is later sold." Id. at $1069 \mathrm{n} .153$. Perhaps unfairly to taxpayers who invest in employment-related education, Regulation section 1.162-5 does not

Pitt Tax Review | ISSN 1932-1821 (print) 1932-1996 (online) DOI 10.5195/taxreview.2017.68 | http://taxreview.law.pitt.edu 
requirements for a $\S 162$ deduction under the standard set forth in Regulation section 1.162-5-were the employee to pay the cost herself-then if her employer instead provides the same education to her as a fringe benefit, the value of that education is excludable from her gross income as a working condition fringe.

For employers who "want to offer some education benefits to certain employees" while avoiding the relative complexity and expense of a $\S 127$ plan, "[t]he working condition fringe benefit offers flexibility" and several distinct advantages. ${ }^{167}$ First, in contrast to $\S 127$ 's $\$ 5,250$ cap on excludability, there is no dollar limit on the amount of employment-related education benefits that can be excluded under $\S 132(a)(3) .{ }^{168}$ Second, for education benefits to be excludable as working condition fringes, there is no need for the employer to provide the benefits pursuant to some written plan meeting particular detailed criteria, as is required under $\S 127 .{ }^{169}$ Third — and often most significantly - the excludability of employment-related education benefits as working condition fringes is not subject to any nondiscrimination requirement. ${ }^{170}$ As a result, an employer can offer education benefits within

contemplate treating as capital expenditures those employment-related educational expenses that fail under Regulation section 1.162-5(b)(2) or (3) to qualify as deductible ordinary expenses. See Lazar, supra note 67, at 1070 ("There is no such thing as a business, capital expenditure for education. There is no justification for a different standard for educational expenses."). For an interesting argument that certain employment-related educational expenditures should qualify for capitalization, and for a proposed method of amortizing such expenditures, see $i d$. at 1117-26.

${ }^{167}$ Fenton, supra note 78 , at 51.

${ }^{168} \mathrm{Id}$. at 52. Although Mr. Fenton and others sometimes refer to the working condition fringe exclusion as the $\S 132$ (d) exclusion, the exclusion itself is technically set forth in $\S 132(a)(3)$. Section 132(d) defines what a working condition fringe is, for purposes of the $\S 132(\mathrm{a})(3)$ exclusion.

${ }^{169}$ Fenton, supra note 78, at 51 ("There is no requirement for a written plan [under $\S 132(d)$ ], nor must the employer notify employees about the benefit."). As a result, employers can avoid the time and expense involved in "draft[ing], implement[ing,] and maintain[ing] a formal written plan." $I d$. at 52. Perhaps even more importantly, not having to meet various detailed requirements of a written plan "also means [that an employer] won't lose its plan qualification [and, thus, the excludability of the benefits] because it misses a procedure." Id. For a description of the requirements for a written plan that exist, in contrast, under $\S 127$, see supra notes 84-94 and accompanying text.

${ }^{170}$ See Fenton, supra note 78, at 52. Section 132(j)(1) provides that the exclusions under $\S 132(a)(1)$ and (2) - for no-additional-cost services and qualified employee discounts, respectively - are available to highly compensated employees only if the employer offers such no-additional-cost services or qualified employee discounts in a manner that does not discriminate in favor of its highly compensated employees. See I.R.C. § 132(j)(1). However, on its face, § 132(j)(1) does not apply in the case of an exclusion under $\S 132(a)(3)$ (for working condition fringes). See id. The only other nondiscrimination provisions within $\S 132$ pertain specifically to the excludability of (1) food in employer-provided eating facilities as a de

Pitt Tax Review | ISSN 1932-1821 (print) 1932-1996 (online)

DOI 10.5195/taxreview.2017.68 | http://taxreview.law.pitt.edu 
the scope of $\S 132(\mathrm{~d})$ to any individual employee or subset of employees whom it chooses - even if it does so in a way that discriminates in favor of its highly compensated employees. ${ }^{171}$

\section{B. For a Faculty Graduate Tuition Reduction to Be a Working Condition} Fringe, the Education's Cost Must Be Deductible Under Regulation Section 1.162-5

In order for $\S 132(a)(3)$ ever to apply to a particular faculty graduate tuition reduction, the tuition reduction must meet the definition of a "working condition fringe" under $\S 132(\mathrm{~d})$. This requires the education to be related to the faculty member's current employment to such an extent that, if she were paying the tuition herself, the cost would qualify as a deductible ordinary business expense under $\S 162 .{ }^{172}$ The question thus becomes: if a faculty member had to cover the costs of the education for which she instead receives a graduate tuition reduction from her university, under what circumstances would such costs meet the standards for deductibility of employment-related education expenses under Regulation section 1.162-5 $?^{173}$ The answer, under the regulations, is that the education in question would have to either (1) "[m]aintain[] or improve[] skills required by the [faculty member in her current] employment" at her university or (2) "[m]eet[] the express requirements of the ... [university], or the requirements of applicable law or regulations," on which the faculty member's continued employment at the university is conditioned. ${ }^{174}$ However, such education could neither

minimis fringe or (2) qualified retirement planning services. See I.R.C. § 132(e)(2), (m)(2). A Treasury regulation on point confirms that no nondiscrimination rule applies to any other category of exclusion within $\S 132$-including the $\S 132$ (a)(3) exclusion for working condition fringes. See Treas. Reg. § 1.132$8($ a)(3) (1989).

${ }^{171}$ See Fenton, supra note 78, at 52. An employer "could, for example, offer [a working condition fringe] benefit to employees it wants to single out for special treatment or move quickly up the [organizational] ladder. Since there are no reporting requirements, there's no need to spread the word to other employees." Id.

${ }^{172}$ See I.R.C. § 132(d); see also supra text accompanying notes 163-66 (discussing same). In such a case, the expense would relate to the taxpayer's "trade or business of being a university professor." Miller \& Pikowsky, supra note 156, at 379.

${ }^{173}$ See supra text accompanying notes 163-66 (discussing Regulation section 1.162-5).

${ }^{174}$ Treas. Reg. § 1.162-5(a) (1967).

Pitt Tax Review | ISSN 1932-1821 (print) 1932-1996 (online) DOI 10.5195/taxreview.2017.68 | http://taxreview.law.pitt.edu 


\section{2 | Pittsburgh Tax Review | Vol. 152017}

(1) constitute the minimum education required for the faculty member's current position at the university ${ }^{175}$ nor (2) qualify the faculty member for a new trade or business - that is, a trade or business other than working in higher education. ${ }^{176}$

1. The Education Must Maintain or Improve Skills Needed in an Employee's Employment or Meet an Express Requirement of the Employee's Employer

If a university faculty member pursues a graduate degree "in excess of [the] minimum education" 177 required for her position, and if such degree does not qualify her for a trade or business other than teaching in higher education, then it generally should be easy for the faculty member to demonstrate that her course of study either (1) "maintains or improves skills required by [her] in [her] employment" requirements of [her] employer." ${ }^{179}$ For example, an assistant professor of civil engineering - who had already met the minimum educational requirements for his position before he pursued a $\mathrm{PhD}$ in civil engineeringwas able to deduct the expense of his $\mathrm{PhD}$ tuition under $\S 162$ because his studies "were made to improve or maintain his skills as a civil engineering teacher at the university level, and that... was [his] existing trade or business" at the time. ${ }^{180}$ Similarly, a taxpayer who had met the minimum requirements for a position as an assistant professor of economics before he pursued a $\mathrm{PhD}$ in economics, was able to deduct the cost of his doctoral studies under $\S 162$ because he undertook those studies "primarily for meeting the express requirements of the university, imposed subsequent to his initial employment, as a condition to [his] retention ... of his salary, status, or employment as an assistant professor." 181 In short, if a university

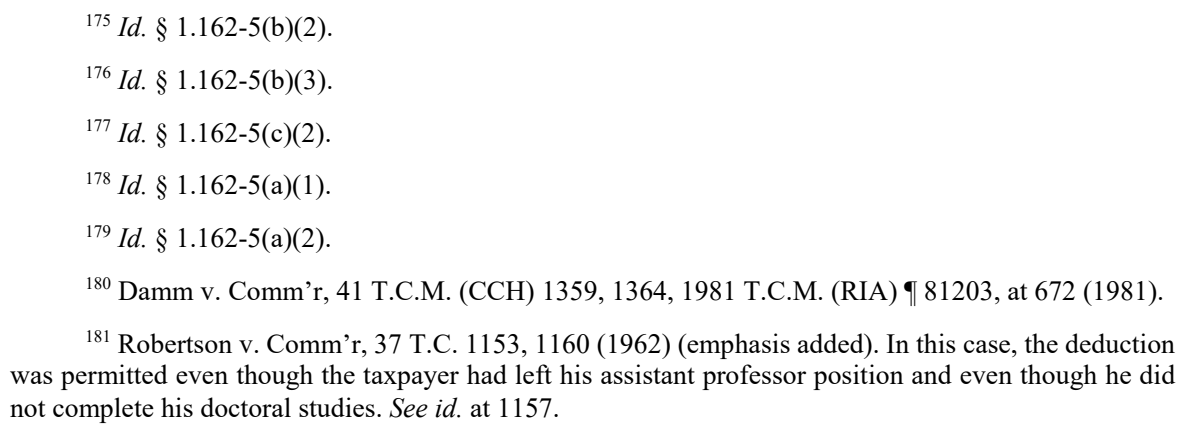

${ }^{181}$ Robertson v. Comm'r, 37 T.C. 1153,1160 (1962) (emphasis added). In this case, the deduction was permitted even though the taxpayer had left his assistant professor position and even though he did not complete his doctoral studies. See id. at 1157.

Pitt Tax Review | ISSN 1932-1821 (print) 1932-1996 (online) DOI 10.5195/taxreview.2017.68 | http://taxreview.law.pitt.edu 
professor's graduate studies do not run afoul of the two "negative" requirements of Regulation section $1.162-5,{ }^{182}$ they will generally satisfy one of Regulation section 1.162-5's alternative "affirmative" requirements. ${ }^{183}$

Nonetheless, there are several sorts of circumstances in which a faculty member's graduate education would fail one or both of Regulation section $1.162-5$ 's "negative" requirements.

2. The Education Cannot Constitute the Minimum Educational Requirement for the Employee's Position

First, the costs of such graduate education are not deductible as a $\S 162$ expense if the education is required of the faculty member "in order to meet the minimum educational requirements for qualification in" her current employment. ${ }^{184}$ "The minimum education necessary to qualify for [any given] position ... must be determined from a consideration of such factors as the requirements of the employer, the applicable law and regulations, and the standards of the profession, trade, or business involved." ${ }^{185}$ Thus, for example, a taxpayer who took a position as an assistant professor of music at a university, immediately upon earning a doctorate in music, was not able to deduct the costs of obtaining her PhD. Under the university's policy at the time the taxpayer was hired, "the normal criteria for appointment to the position of assistant professor include[d] a minimum educational level of a doctorate (Ph.D.) degree in the appropriate field." ${ }^{186}$ Similarly, doctoral students who were graduate teaching and research assistants at their universities could not deduct the costs of their PhD studies. Their doctorates were "required in order to meet the minimum educational requirements for qualification ... in [their] intended trade or business of being a teacher or professor at the college or university level." 187

\footnotetext{
${ }^{182}$ See Treas. Reg. § 1.162-5(b)(2), (3).

${ }^{183}$ See id. $\S 1.162-5(\mathrm{a})(1)-(2)$.

${ }^{184} I d . \S 1.162-5(\mathrm{~b})(2)(\mathrm{i})$.

${ }^{185} \mathrm{Id}$.

${ }^{186}$ I.R.S. Priv. Ltr. Rul. 93-16-005 (Jan. 12, 1993).

187 Jungreis v. Comm'r, 55 T.C. 581, 592-93 (1970); Holstein v. Comm'r, 29 T.C.M. (CCH) 1687, 1690, 1970 T.C.M. (RIA) 970,348 , at 1848 (1970). In each of the foregoing cases, the taxpayer unsuccessfully argued that he or she had already met the minimum requirements for the position of
}

Pitt Tax Review | ISSN 1932-1821 (print) 1932-1996 (online) DOI 10.5195/taxreview.2017.68 | http://taxreview.law.pitt.edu 
As the regulations make clear, the fact that an individual is already employed in a particular position "does not establish that he has met the minimum educational requirements for qualification in that employment."188 Instead, in the case of an employee of an educational institution, in particular, the employee's minimum educational requirement for her current position "is the minimum level of education ... which under the applicable laws or regulations, in effect at the time [the employee] is first employed in such position, is normally required of an individual initially being employed in such a position." 189 Thus, if a taxpayer is hired for a temporary teaching position, and if such position is to become permanent only if the taxpayer attains an additional graduate degree, then the cost of getting that degree would not be deductible under $\S 162$. In such a case, the graduate degree would be the minimum educational requirement for the position. The regulations illustrate this rule in the following example:

D, who holds a bachelor's degree, obtains temporary employment as an instructor at University $\mathrm{Y}$ and undertakes graduate courses as a candidate for a graduate degree. D may become a faculty member only if he obtains a graduate degree and may continue to hold a position as instructor only so long as he shows satisfactory progress towards obtaining this graduate degree. The graduate courses taken by $\mathrm{D}$ constitute education required to meet the minimum educational requirements for qualification in D's trade or business and, thus, the expenditures for such courses are not deductible. ${ }^{190}$

Consider, for example, a university whose current general policy is to require a $\mathrm{PhD}$ of anyone whom it hires for the position of assistant professor. Now, imagine that the university hires someone with only a master's degree for a tenure-track assistant professor position, on the condition that the new hire will not be eligible to receive tenure unless she attains a PhD by some certain date. Under the foregoing rule, the assistant professor would not be permitted to deduct the cost of her doctoral studies under $\S 162$ because her $\mathrm{PhD}$ would constitute the minimum educational requirement for her position.

university teaching because he or she met the requirements for being a graduate teaching and research assistant. In both cases, however, the Tax Court found that employment as a regular faculty member was a different trade or business than employment as a graduate assistant. See Jungreis, 55 T.C. at 589-91; Holstein, 29 T.C.M. (CCH) at 1689-90, 1970 T.C.M. (RIA) $\uparrow ~ 70,348$, at 1847-48.

${ }^{188}$ Treas. Reg. § 1.162-5(b)(2)(i); see also Lazar, supra note 67, at 1067 (discussing same).

${ }^{189}$ Treas. Reg. $\$ 1.162-5(\mathrm{~b})(2)(\mathrm{ii})$.

${ }^{190} I d$. § 1.162-5(b)(2)(iii), ex. (2).

Pitt Tax Review | ISSN 1932-1821 (print) 1932-1996 (online)

DOI 10.5195/taxreview.2017.68 | http://taxreview.law.pitt.edu 
In contrast, imagine a university who hired a now-tenured professor with only a master's degree, some fifteen or twenty years ago-when its standard policy was to require no more than a master's degree for its regular, full-time faculty. Imagine further that the university has since adopted a different policy, perhaps in response to new accreditation requirements or changing industry norms. Today, the university requires all new faculty hires to have a PhD. What if the veteran, tenured professor now decides to get a doctorate? Would the cost of her doctoral education be deductible as a $\S 162$ expense (assuming she pays the cost herself)? Or would such expense be nondeductible on the ground that the $\mathrm{PhD}$ was now the minimum educational requirement for her position? Happily, in such case, the cost of the professor's doctorate would qualify for the $\S 162$ deduction. ${ }^{191}$ In determining whether an educational institution employee has met the minimum educational requirements for a given position, one must look to the school's requirements that were "in effect at the time [when the employee was] first employed in such position." ${ }^{192}$ However, "[o]nce an individual has met the minimum educational requirements for qualification in his employment... (as in effect when he enters the employment... ), he shall be treated as continuing to meet those requirements even [if the minimum requirements for the position are subsequently] changed."193

\section{The Education Cannot Qualify an Employee for a New Trade or} Business

The second way in which a faculty member's graduate education could fail one of Regulation section 1.162-5's "negative" requirements would be if the education qualifies the faculty member for a new trade or business. ${ }^{194}$ Since 1967, whether a particular degree qualifies a taxpayer for a trade or business other than the one in which she is currently engaged, has been

${ }^{191}$ Cf. Robertson v. Comm'r, 37 T.C. 1153, 1159-60 (1962) (cost of pursuing a PhD deductible where taxpayer had been appointed as an assistant professor at a time when the employer-university did not require its faculty to have doctorates, notwithstanding that the school later changed its policy and required faculty to attain doctorates).

192 Treas. Reg. § 1.162-5(b)(2)(ii).

${ }^{193}$ Id. $\S 1.162-5(\mathrm{~b})(2)(\mathrm{i})$ (emphasis added); see also Lazar, supra note 67, at 1067 (noting that, "once such requirement is satisfied ... an individual will be treated in effect as meeting the minimum educational requirement for his trade or business even if such requirement later changes").

194 Treas. Reg. § 1.162-5(b)(3)(i).

Pitt Tax Review | ISSN 1932-1821 (print) 1932-1996 (online) DOI 10.5195/taxreview.2017.68 | http://taxreview.law.pitt.edu 
determined on the basis of an "objective" test. ${ }^{195}$ The question under this test is simply whether the taxpayer could use the degree to enter a new line of work. Under the current regulations, whether the taxpayer actually intends to use the degree to begin a new career is irrelevant. ${ }^{196}$

A classic example of an educational expense that fails the objective new-trade-or-business-qualification test is when a university professor obtains a law degree to enhance her teaching in some discipline other than law. For example, the IRS declined to allow a $\S 162$ deduction for law school tuition claimed by an associate professor of communications who (1) taught a course concerning "the legal aspects of mass communication," (2) saw "the value of a law degree as an adjunct to [his or her] Ph.D. in Mass Communication," and thus (3) "enrolled in a degree program to acquire a law degree." ${ }^{197}$ Even though the taxpayer's "sole purpose in attending law school [was] to improve [his or her] knowledge and skills as a journalism law professor," the tuition expenses were nondeductible because the law degree qualified the professor for a new trade or business - that is, the practice of law. ${ }^{198}$ In reaching its conclusion, the IRS specifically noted an example in the regulations, which expressly provides that a taxpayer who "obtains a [law] degree required by his employer is not entitled to deduct the cost of law school even though he plans to continue his nonlegal profession. He is not

${ }^{195}$ Regulation section $1.162-5$ was originally promulgated in 1958 , but substantially revised in 1967. See Kalafat, supra note 15, at 1997-2001 (discussing 1958 and 1967 versions of Regulation section 1.162-5); Lazar, supra note 67, at 1063-68 (same). The 1967 regulations "remain unaltered in effect today and have been upheld consistently by the courts." Lazar, supra note 67, at 1066 (citing cases). Under the 1958 regulations, a $\S 162$ education expense deduction was disallowed if "the taxpayer undertook the education 'primarily for the purpose' of ... 'obtaining a new position." Kalafat, supra note 15, at 1997 (quoting the 1958 version of Regulation section 1.162-5(b)). "The most substantial change [from the 1958 regulations to the 1967 regulations] was the elimination of the subjective 'primary purpose' test and its replacement by a more objective test." Lazar, supra note 67, at 1066; see also Kalafat, supra note 15, at 2000 ("Most importantly, the current regulation boasts an objective standard intended to replace the 1958 regulation's unworkable subjective 'primary purpose' test.").

196 "If the education leads to qualifying the taxpayer for a new trade or business, evidence that the taxpayer never intended to enter such trade or business is irrelevant under the 1967 regulation." Kalafat, supra note 15, at 2000-01, quoted in Lazar, supra note 67, at 1067. "The 1958 regulation, on the other hand, relied on the primary purpose approach and, therefore, the taxpayer's subjective intent and purpose was often the determining factor." Kalafat, supra note 15, at 2001.

${ }^{197}$ I.R.S. Priv. Ltr. Rul. 84-32-028 (May 3, 1984).

${ }^{198} I d$.

Pitt Tax Review | ISSN 1932-1821 (print) 1932-1996 (online)

DOI 10.5195/taxreview.2017.68 | http://taxreview.law.pitt.edu 
entitled to a deduction because the course of study qualifies him for a new trade or business." 199

Similarly, in Ardavany v. Commissioner, ${ }^{200}$ the taxpayer-"a community college instructor of business subjects" with "both a bachelor's and master's degree in business education"- - had already met her community college district's "minimum qualifications to teach business law courses."201 Nevertheless, when her college "decided to require its business law instructor to have a more comprehensive legal background," the school "encouraged the [taxpayer] to go to law school." ${ }^{202}$ In response, the taxpayer obtained a law degree, and she sought to deduct her law school tuition under $\S 162$. She argued that she was entitled to the deduction because "she was required by her employer to obtain a law degree in order to be retained on the teaching staff as a business law teacher" and that "a law degree serve[d] to maintain and improve her skills as a business law teacher." 203 She also asserted that "she did not take the law degree with any intent to practice law.",204

Nonetheless, the Tax Court disallowed the deduction. The court noted that, under Regulation section 1.162-5(b)(3), "even though education [meets] the express requirements of the taxpayer's employer or [improves] the skills of a taxpayer in his employment ... the expenses are not deductible if they are for education [that leads to] qualifying the taxpayer in a new trade or business." ${ }^{205}$ In the case in question, the court found that the taxpayer "by attending law school ha[d] clearly qualified for a new trade or business apart from her employment in the nonlegal field of teaching business courses."206 Thus, under the regulations, the taxpayer's law school expenses were

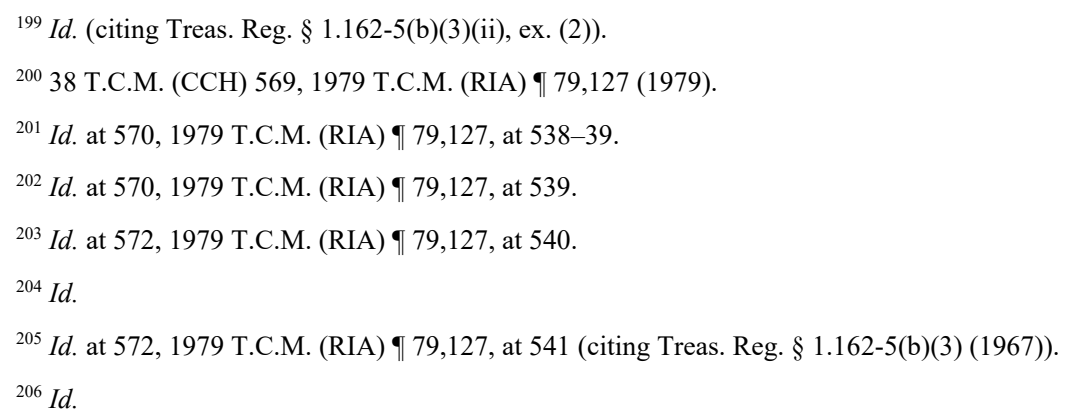

Pitt Tax Review | ISSN 1932-1821 (print) 1932-1996 (online) DOI 10.5195/taxreview.2017.68 | http://taxreview.law.pitt.edu 
nondeductible. "The fact that the taxpayer[] ... did not practice law or did not intend to practice law was . . . irrelevant."207

Regulation section 1.162-5(b)(3) states that, "in the case of an employee, a change of duties does not constitute a new trade or business if the new duties involve the same general type of work as is involved in the individual's present employment." ${ }^{208}$ What this means is not entirely clear"except in the case of teachers, in which case the regulation considers all teaching and related duties to involve the same general type of work." ${ }^{209}$ In particular, the regulation specifies that each of the following changes of duties does not constitute entering into a new trade or business: (1) a change from "[e]lementary to secondary school classroom teacher," (2) a change from "[c]lassroom teacher in one subject (such as mathematics) to classroom teacher in another subject (such as science)," (3) a change from "[c]lassroom teacher to guidance counselor," or (4) a change from "[c]lassroom teacher to principal." 210

Under this rule, for instance, if a university professor with a $\mathrm{PhD}$ in mathematics decided to pursue a second $\mathrm{PhD}$ in physics so that she could change teaching disciplines, she could reasonably take the position that the cost of pursuing her physics doctorate should be deductible under $\S 162 .^{211}$

${ }^{207} I d$. The Tax Court further noted that, in prior cases, it had "considered other situations of taxpayers who, as a means to maintain or improve skills in their respective professions, had attended law school." Id. (citing cases of taxpayers who were accountants or internal revenue agents, respectively). In those cases, the Tax Court "held that the educational expenses were nondeductible." Id. Once again, the fact that the taxpayers in those cases did not intend actually to practice law was irrelevant. Id.

${ }^{208}$ Treas. Reg. $\S 1.162-5(b)(3)(i)$.

${ }^{209}$ Kalafat, supra note 15, at 2010 (emphasis added).

${ }^{210}$ Treas. Reg. $\S 1.162-5(b)(3)(i)$.

${ }^{211}$ This assumes, of course, not only that she paid the cost of her doctoral studies herself, but also that her first $\mathrm{PhD}$ had satisfied the minimum educational requirement for her current faculty position and that the second $\mathrm{PhD}$ either maintains or improves her skills as a professor or meets an express requirement of her university-employer. Of course, one can do more with a physics PhD than teach. To that extent, a physics doctorate could, in theory, be characterized as qualifying its recipient for a new trade or business. But, the same could be said of many "science" degrees generally. Thus, while the issue may not be entirely free from doubt, it is nevertheless reasonable to infer, from the math-teacher-to-science-teacher example in Regulation section 1.162-5(b)(3)(i), that the cost of education undertaken to enable an instructor to switch from teaching in one academic discipline to another would not be deemed nondeductible on the ground that the education qualified the instructor for a new trade or business - unless, of course, the program of study led to a distinctly professional degree, such as a law degree.

Pitt Tax Review | ISSN 1932-1821 (print) 1932-1996 (online)

DOI 10.5195/taxreview.2017.68 | http://taxreview.law.pitt.edu 
Analogizing to the regulation's example of the change from a classroom teacher in mathematics to a classroom teacher in science, the professor could argue that to teach university-level physics (rather than mathematics) after receiving the second $\mathrm{PhD}$ would not be to engage in a new trade or business. ${ }^{212}$

As an illustration of just how broadly the regulation conceives of the singular trade or business of "educator," consider the case of a taxpayer who was a professor of education at a college and who sought "to be placed on an eligibility list for appointment as president of a junior college within the same educational system." 213 At the time, he had only a master's degree, which was the minimum educational requirement for his professor position. ${ }^{214}$ However, the president position required a $\mathrm{PhD}$, so he enrolled in a doctoral program in the field of education. ${ }^{215}$ As the reader might have guessed, the taxpayer claimed a $\S 162$ deduction for the cost of obtaining his $\mathrm{PhD}$. And, as the reader might not have guessed, the IRS allowed the deduction. ${ }^{216}$ The IRS found that the taxpayer's doctoral studies "maintain[ed] or improve[d] skills required in his employment" and that the $\mathrm{PhD}$ was not "the minimum educational requirement[] for qualification in his employment."217 Significantly, in making the latter finding, the IRS emphasized that the taxpayer's "appointment as president of a junior college would not be a new trade or business but merely a change of duties in the same general type of work involved in his present employment as a teacher." 218

For any particular graduate course that a university professor might take, one can ask whether-under the above-described parameters of Regulation

\footnotetext{
${ }^{212}$ Of course, if after getting her physics $\mathrm{PhD}$, the taxpayer were to leave the field of higher education and take a job as a physicist—say, for a corporation — the result would most likely be different. In this latter scenario, the second $\mathrm{PhD}$ would almost certainly be considered to have qualified the taxpayer for her new trade or business of being employed as a physicist - in which case, the cost of the doctoral studies would be nondeductible under $§ 162$.

${ }^{213}$ Rev. Rul. 68-580, 1968-2 C.B. 72.

${ }^{214} I d$.

${ }^{215} \mathrm{Id}$.

${ }^{216} I d$.

${ }^{217} I d$.

${ }^{218}$ Id. (citing Treas. Reg. § 1.162-5(b)(3) (1967)).
}

Pitt Tax Review | ISSN 1932-1821 (print) 1932-1996 (online) DOI 10.5195/taxreview.2017.68 | http://taxreview.law.pitt.edu 


\section{0 | Pittsburgh Tax Review | Vol. 152017}

section 1.162-5- the cost of the course would qualify as deductible under $\S 162$ if the professor paid for the course herself. ${ }^{219}$ If the answer is "yes," then a tuition reduction that her university provides to her for the same course would come within $\S 132$ (d)'s "working condition fringe" definition. On the other hand, if the answer is "no," then a tuition reduction for such a course could not be excludable as a working condition fringe.

\section{THE § 132(A)(3) EXCLUSION APPLIES TO GRADUATE TUITION REDUCTIONS THAT ARE "WORKING CONDITION FRINGES" UNDER $\S$ 132(D)—NOTWITHSTANDING THE IRS'S CURRENT POLICY TO THE CONTRARY}

In general, if an employer offers employment-related education benefits that meet the definition of a "working condition fringe" under $\S 132(d)$, those benefits are always excludable under $\S 132(a)(3)$ - regardless of whether any portion of those benefits would also be excludable under $\S 127 .{ }^{220}$ Nonetheless, the IRS applies a different standard in the particular case of universities that offer graduate tuition reductions to their employees. In its most recent pronouncement on the subject, the IRS has taken the position that a graduate tuition reduction for a university employee-even if otherwise a working condition fringe under $\S 132(\mathrm{~d})$ - is not excludable under $\S 132(\mathrm{a})(3)$ unless the first $\$ 5,250$ of the reduction is excludable under $\S 127.221$ This means that, under current IRS policy, a faculty graduate tuition reduction will be treated as excludable only if the university provides it under an educational assistance program that meets all of $\S 127$ 's requirements (including the nondiscrimination requirement). As detailed below, however, the IRS's position is founded on a misreading of the applicable Code provisions and Treasury regulations and a misunderstanding of the relevant legislative history.

\footnotetext{
${ }^{219}$ Of course, the discussion above sets forth only the parameters of the rules, generally. Because the Regulation section 1.162-5 test is so fact specific, any particular course of study undertaken by any particular taxpayer must be evaluated according to the specific facts and circumstances of the case. See Cheney, supra note 95, at 515 (discussing fact-specific nature of the Regulation section 1.162-5 analysis).

${ }^{220}$ See supra notes $153-54$ and accompanying text.

${ }^{221}$ See I.R.S. Non-Docketed Serv. Adv. Review 2010-39-01F (July 27, 2010).
}

Pitt Tax Review | ISSN 1932-1821 (print) 1932-1996 (online) DOI 10.5195/taxreview.2017.68 | http://taxreview.law.pitt.edu 
A. Section 132(1) Does Not Prevent the § 132(a)(3) Exclusion from Applying to a Graduate Tuition Reduction-Even Though \& 117(d) Also Pertains to the Tax Treatment of Graduate Tuition Reductions

Whether a faculty graduate tuition reduction is ever excludable as a working condition fringe depends, in large part, on whether $\S 132(l)$ applies. Section 132(l) says that, if the tax treatment of a particular fringe benefit is provided for in a Code section other than $\S 132$, then the only provisions within $\S 132$ that may apply to such benefit are those pertaining to de minimis fringes or qualified moving expense reimbursements. ${ }^{222}$ Thus, if the tax treatment of a graduate tuition reduction is governed by some other Code provision, $\S 132(l)$ prevents the exclusion of such tuition reduction under $\S 132(a)(3)$.

The threshold question is whether, for purposes of $\S 132(l)$, the tax treatment of faculty graduate tuition reductions is covered by $\S 117(\mathrm{~d})$. As indicated by both the Treasury regulations and $\S 132(l)$ 's legislative history, the answer would seem to be "yes." ${ }^{23}$ Section 117(d) sets forth general parameters as to which tuition reductions by an educational organization for an employee are excludable from - and which others are includible in - the employee's gross income. Section 117(d)(2) defines the subset of tuition reductions that constitute "qualified tuition reductions." ${ }^{224}$ Section 117(d)(1),

${ }^{222}$ Specifically, § 132(l) states that "section [132] (other than subsections (e) and (g)) shall not apply to any fringe benefits of a type the tax treatment of which is expressly provided for in any other section of [Chapter 1 of Subtitle A of the Code]." I.R.C. § 132(l). Section 132(e) defines "de minimis fringes," which are excludable under § 132(a)(4). I.R.C. § 132(a)(4), (e). Section 132(g) defines "qualified moving expense reimbursements," which are excludable under § 132(a)(6). I.R.C. § 132(a)(6), (g).

${ }^{223}$ As explained in " $[\mathrm{t}] \mathrm{he}$ House Report for the Deficit Reduction Act of 1984 (DEFRA), which enacted Code $\S 132, \ldots$ ' '[a] benefit is not excludable under new Code section $132 \ldots$ if another section of the Internal Revenue Code provides rules for the tax treatment of the general type of benefit." I.R.S. Field Serv. Adv. 2002-31-016 (Mar. 13, 2002) (quoting H.R. REP. No. 98-432, pt. 2, at 1608 (1984)) (alteration in original). Thus, "because section 117(d) applies to tuition reductions, the exclusions under section 132 do not apply to free or discounted tuition provided to an employee by an organization operated by the employer, whether the tuition is for study at or below the graduate level." Treas. Reg. § 1.1321(f)(1) (as amended in 1993). But see id. (last sentence) ("Of course, if the amounts . . . are for education relating to the employee's trade or business of being an employee of the employer . . . the education may be eligible for exclusion as a working condition fringe.").

${ }^{224}$ I.R.C. $\S 117(d)(2)$.

Pitt Tax Review | ISSN 1932-1821 (print) 1932-1996 (online) DOI 10.5195/taxreview.2017.68 | http://taxreview.law.pitt.edu 


\section{2 |Pittsburgh Tax Review | Vol. 152017}

in turn, provides an exclusion for qualified tuition reductions only. ${ }^{225}$ As explained above, a graduate tuition reduction that a university grants to its faculty member is not a qualified tuition reduction under $\S 117(\mathrm{~d})(2)$ - at least, not under the IRS's interpretation ${ }^{226}$ - and thus is not excludable under $\S 117(\mathrm{~d})(1){ }^{227}$ Therefore, unless some separate exclusion provision applies to the same benefit, such a tuition reduction must be included in the recipient's gross income. To that extent, at least, $\S 117(\mathrm{~d})$ thus provides for the tax treatment of a faculty member's graduate tuition reduction.

Accordingly, if a university provides a faculty member with a graduate tuition reduction that is nothing other than that, then $\S 132(l)$ plainly applies and the tuition reduction is not excludable under $\S 132 .{ }^{228}$ This outcome makes perfect sense, because it blocks an end-run around $\S 117(\mathrm{~d})$ 's general rules for the treatment of tuition reductions. Imagine, for example, that a university provides a tuition reduction for graduate coursework that its faculty member takes simply for her personal enrichment. Or, imagine that the university provides a graduate tuition reduction for the faculty member's spouse or child. In neither case does $\S 117(\mathrm{~d})$ allow an exclusion of the tuition reduction. ${ }^{229}$ At the same time, the faculty member should not be permitted to circumvent the limits of the $\S 117$ (d) exclusion by excluding the tuition

${ }^{225}$ Id. $\S 117(\mathrm{~d})(1)$.

${ }^{226}$ As described above, the IRS considers such tuition reductions to be outside the scope of $\S 117(d)(2)$ because it interprets $\S 117$ (d)(5) to apply only to graduate tuition reductions for a university's graduate teaching and research assistants, and not to graduate tuition reductions for a university's regular faculty or staff. See supra Part II.A. But see supra Part II.B. (discussing how the IRS's interpretation of $\S 117(\mathrm{~d})(5)$ is subject to challenge).

${ }^{227}$ The unavailability of the $\S 117$ (d) exclusion for faculty graduate tuition reductions is discussed, generally, supra Part II.

${ }^{228}$ This assumes that the amount of the tuition reduction is large enough to preclude the benefit from being a de minimis fringe under $\S 132(\mathrm{e})$.

${ }^{229}$ There is no $\S 117$ (d) exclusion in the former case because a tuition reduction for a faculty member's own graduate studies is not a qualified tuition reduction under the IRS's interpretation of $\S 117(d)(5)$ and, even if the IRS's interpretation is wrong, the exclusion of such a tuition reduction would likely be prohibited under $\S 117$ (d)(3) in any event. See supra Part II.A, C. There is no $\S 117(\mathrm{~d})$ exclusion in the latter case because only undergraduate tuition reductions for an educational organization employee's spouse or dependent children are qualified tuition reductions. See I.R.C. § 117(d)(2).

Pitt Tax Review | ISSN 1932-1821 (print) 1932-1996 (online)

DOI 10.5195/taxreview.2017.68 | http://taxreview.law.pitt.edu 
reduction as a no-additional-cost service $^{230}$ or a qualified employee discount. ${ }^{231}$ And that is exactly what $\S 132(l)$ prevents. Not coincidentally, this result is consistent with $\S 132(\mathrm{j})(8)$ 's denial of any $\S 132$ exclusionother than the working condition fringe exclusion-for employer-provided education benefits generally. ${ }^{232}$

But what if a university provides its faculty member with a tuition reduction for a graduate degree that meets the standards for employmentrelated education under Regulation section 1.162-5? In that case, the benefit in question is not only a graduate tuition reduction, but also a working condition fringe. ${ }^{233}$ Just because such benefit cannot be excluded as a qualified tuition reduction under $\S 117(\mathrm{~d})$, does that mean that it should also not be excludable as a working condition fringe under $\S 132(\mathrm{a})(3)$ ? Applying $\S 132(l)$ to reach that conclusion would seem notably unfair, as it would require the faculty member to include in income something her employer provided simply to further her job performance. ${ }^{234}$ It would require her to include the value of something whose cost would qualify as a deductible

\footnotetext{
${ }^{230}$ For a discussion of the no-additional-cost service exclusion under $\S 132(a)(1)$ and how a faculty graduate tuition reduction might come within the definition of a "no-additional-cost service" under $\S 132$ (b) (were it not for § 132(j)(8)), see supra note 150.

${ }^{231}$ For a discussion of the qualified employee discount exclusion under $\S 132(a)(2)$ and how at least a portion of a faculty graduate tuition reduction might constitute a qualified employee discount under $\S 132(\mathrm{c})(1)(\mathrm{B})$, if it were not for $\S 132(\mathrm{j})(8)$, see supra note 151 .

${ }^{232}$ For a discussion of $\S 132(\mathrm{j})(8)$, see supra notes $153-54$ and accompanying text.

${ }^{233}$ For an explanation of how employer-provided educational benefits can constitute working condition fringes under $\S 132$ (d) if the education meets the standards under Regulation section 1.162-5, see supra notes 163-66. For a description of how faculty graduate tuition reductions, in particular, can meet the Regulation section 1.162-5 standards and thus be working condition fringes, see supra Part IV.B.

${ }^{234}$ The reason for the trade or business expense deduction under $\S 162$ is that, in order to measure accurately the amount of a taxpayer's business income that ought to be included in the tax base for the federal income tax, one must subtract the taxpayer's costs of producing that income. "Business expenses must necessarily be deductible if the income tax is to be imposed on 'income' . . .." Lazar, supra note 67, at 1068; see also MARVIn A. ChIRELSTEIn \& LAWRENCE ZelenAK, Federal InCOME TAXATION 114 (12th ed. 2012) (noting that a taxpayer's business receipts net of business expenses "is the only suitable measure of the taxpayer's 'income' properly so-called"). By parity of reasoning, to include in a taxpayer's income the value of an employer-provided benefit, the purpose of which is to help the taxpayer do her job - that is, to facilitate the taxpayer's production of income from the trade or business of being an employee - would be to tax her on an amount greater than her actual income. That is the essential logic underlying the $\S 132(a)(3)$ working condition fringe exclusion. Such logic equally obtains when the working condition fringe is provided by an educational-organization employer to a faculty member or other employee in the form of a graduate tuition reduction.
}

Pitt Tax Review | ISSN 1932-1821 (print) 1932-1996 (online) DOI 10.5195/taxreview.2017.68 | http://taxreview.law.pitt.edu 
ordinary business expense under $\S 162$ if she paid for it herself. ${ }^{235}$ Moreover, such an outcome would present something of a horizontal equity problem ${ }^{236}$ because it would put employees of educational organizations at a unique disadvantage: It would deny faculty members and other university employees an exclusion for kinds of employer-provided, employment-related education that employees in other lines of work can normally exclude as working condition fringes. ${ }^{237}$

${ }^{235}$ If such cost were an unreimbursed employee expense, the expense would be a "miscellaneous" itemized deduction under $\S 67$ (b). For taxable years beginning prior to 2018 , such expense would thus be deductible to the extent that (1) the expense amount (together with any other miscellaneous itemized deductions for the year) exceeds (2) two percent of the employee's adjusted gross income. I.R.C. § 67(a); see also supra notes 159 and 161. Under new $\S 67(\mathrm{~g})$ (which was added under the Tax Cuts and Jobs Act enacted at the end of 2017), miscellaneous itemized deductions are disallowed "for any taxable year beginning after December 31, 2017, and before January 1, 2026." Tax Cuts and Jobs Act, Pub. L. No. 115-97, §11045, 131 Stat. 2054, 2088 (2017); see also supra note 159 and accompanying text. Nonetheless, unreimbursed employee expenses still constitute trade or business expenses under $\S 162-$ which is what matters for purposes of determining whether a faculty member's employer-provided graduate education is a working condition fringe under $\$ 132(d)$. See supra text accompanying notes 160 62. Moreover, if the faculty member paid the cost of the education and were then reimbursed for such cost under the university's accountable reimbursement plan, she would be able to deduct the entire amount of such reimbursement as a deduction in arriving at adjusted gross income. See I.R.C. §62(a)(2)(A) (providing that reimbursed employee expenses are deductible in computing AGI). Thus, permitting the faculty member to exclude the value of her graduate tuition reduction - when it is a working condition fringe - would put her in the same position as if she had paid the cost of the education and had then been reimbursed by her university. See supra note 162 .

${ }^{236}$ Horizontal equity "is the principle that taxpayers who are positioned identically relative to the tax base should pay equal tax." Ira K. Lindsay, Tax Fairness by Convention: A Defense of Horizontal Equity, 19 Fla. TAX REV. 79, 80-81 (2016).

${ }^{237}$ Similarly, to make the applicability of $\S 132$ (a)(3) contingent on the applicability of $\S 127$-as per current IRS policy in the particular case of graduate tuition reductions - is to impose, on university faculty, conditions for the working condition fringe exclusion that are not imposed on employees in any other line of work. See infra Part V.B.2 (describing IRS's position that the § 132(a)(3) exclusion can apply to a graduate tuition reduction only if $\S 127$ also applies). First and foremost, tying the $\S 132(a)(3)$ exclusion to the $\S 127$ exclusion imposes a nondiscrimination requirement that does not exist for working condition fringes in any other context. See supra notes 170-71 and accompanying text (noting that $\S 132$ (a)(3) does not have a nondiscrimination requirement). Second, making the former exclusion dependent on the latter means that, in contrast to working condition fringes generally, graduate tuition reductions are never excludable unless the university-employer has gone to the trouble and expense of adopting (and communicating) a detailed, written benefit plan meeting all of $\S 127$ 's other requirements. See supra note 169 and accompanying text (contrasting such requirements under $\S 127$ with the lack thereof under $\S 132(a)(3))$. In short, placing § 127's conditions on the applicability of $\S 132(a)(3)$ works to deny university faculty (and other university employees) a working condition fringe exclusion for graduate tuition reductions in circumstances under which employees in other industries can usually exclude their working condition fringes.

Pitt Tax Review | ISSN 1932-1821 (print) 1932-1996 (online)

DOI 10.5195/taxreview.2017.68 | http://taxreview.law.pitt.edu 
When a graduate tuition reduction is also a working condition fringe, a $\S 132(\mathrm{a})(3)$ exclusion does not circumvent or contradict the tax rules that usually govern the type of benefit in question. The reason, quite simply, is that the working condition fringe exclusion pertains to working condition fringes generally. In other words, no Code section outside of $\S 132$ provides for how to treat working condition fringes. Rather, the tax treatment of working condition fringes is covered, in the first instance, by $\S 132(a)(3)$ and 132(d). As a result, $\S 132(l)$ does not apply in the case of a working condition fringe - even if the employer is an educational organization and the working condition fringe is in the form of a graduate tuition reduction. Importantly, under this interpretation, $\S 132(l)$ is yet again consistent with $\S 132(\mathrm{j})(8)$. Pursuant to the latter provision, an employer-provided educational benefit is still excludable as a working condition fringe, even though no other $\S 132$ exclusion can apply. ${ }^{238}$

${ }^{238}$ Note that $\S 132(j)(8)$ allows the $\S 132(a)(3)$ exclusion when an educational benefit is also a working condition fringe, even though $\S 127$ generally governs the tax treatment of employer-provided education benefits. See I.R.C. § 132(j)(8); see also supra notes 153-54 and accompanying text. Consistent with $\S 132(l)$ - as interpreted above $-\$ 132(\mathrm{j})(8)$ permits the working condition fringe exclusion in order to prevent the taxation of what is essentially a nondiscretionary business expenditure, even when another Code section (such as $\S 127$ or $\S 117(\mathrm{~d})$ ) would potentially limit or deny any exclusion of the benefit in question. As explained above, the working condition fringe exclusion prevents overtaxing of an employee's "income" in essentially the same way as the $\S 162$ deduction for employee expenses. See supra notes 234-35. A trade or business expense (including an expense in connection with the trade or business of being an employee) "is nondiscretionary in the sense that the [taxpayer's] income is conditioned on the outlay." Lazar, supra note 67, at 1068. For that reason, such expenses are qualitatively different from personal expenditures, which simply "reflect the disposition which the taxpayer elects to make out of the wealth that she has earned." Id. Because personal expenditures are merely choices about how to spend income, rather than costs incurred to produce such income, they are generally not deductible - unless some particular Code section provides a deduction of the particular personal expenses in question. See I.R.C. § 262(a); see also Lazar, supra note 67, at 1069 (discussing same). Just as a fringe benefit is a working condition fringe if it is an expenditure to aid in the production of the taxpayer's income from her employment, a fringe benefit that is purely personal in nature is akin to a discretionary personal expenditure. By analogy to $\S 262$, fringe benefits in the latter category should not be excludable, except to the extent that the Code section governing the treatment of the particular type of benefit in question otherwise provides for an exclusion. This explains, for example, why (1) a tuition reduction for a faculty member's employment-related graduate education should be excludable as a working condition fringe, whereas (2) a tuition reduction for graduate education solely for the faculty member's personal enrichment should be included in the faculty member's gross income except to the extent otherwise excludable under $§ 127$.

Pitt Tax Review | ISSN 1932-1821 (print) 1932-1996 (online)

DOI 10.5195/taxreview.2017.68 | http://taxreview.law.pitt.edu 
An interpretive regulation under $\S 132$ is directly on point, and it echoes the foregoing reading of $\S 132(l)$. Regulation section 1.132-1(f)(1) states, in pertinent part, as follows:

\begin{abstract}
If the tax treatment of a particular fringe benefit is expressly provided for in another section of Chapter 1 of the Internal Revenue Code of 1986, section 132 and the applicable regulations (except for section 132(e) and the regulations thereunder) do not apply to such fringe benefit. For example . . . because section 117 (d) applies to tuition reductions, the exclusions under section 132 do not apply to free or discounted tuition provided to an employee by an organization operated by the employer, whether the tuition is for study at or below the graduate level. $O f$ course, if the amounts paid by the employer are for education relating to the employee's trade or business of being an employee of the employer so that, if the employee paid for the education, the amount paid could be deducted under section 162, the costs of the education may be eligible for exclusion as a working condition fringe. ${ }^{239}$
\end{abstract}

Essentially, Regulation section 1.132-1(f)(1) says that, because $\S 117(d)$ deals with the tax treatment of tuition reductions granted by educational organizations to their employees generally, a graduate tuition reduction provided by a university to its employee cannot be excluded under any prong of $\S 132$ unless such tuition reduction constitutes a working condition fringe. The gist of Regulation section 1.132-1(f)(1) is that, if a graduate tuition reduction is for employment-related education that meets Regulation section $1.162-5$ 's standards (so that the cost of the education would qualify as deductible under $\S 162$ if the employee paid for it herself), the tuition reduction is excludable under $\S 132(\mathrm{a})(3)$ as a working condition fringe. On the other hand, if the education in question does not meet the Regulation section 1.162-5 test, then the tuition reduction cannot be excluded as-for example - a no-additional-cost service under $\S 132(\mathrm{a})(1)$ or a qualified employee discount under $\S 132(a)(2) .{ }^{240}$

At one time, the IRS itself embraced this commonsense interpretation of $\S 132(l)$. Recall the 1990 private letter ruling, discussed above, in which the IRS determined that graduate tuition reductions provided by a university to its regular faculty or other employees (besides graduate teaching and

${ }^{239}$ Treas. Reg. § 1.132-1(f)(1) (as amended in 1993) (emphasis added).

${ }^{240}$ See Dodge, supra note 3, at 742 n.256 (construing Regulation section 1.132-1(f)(1) to mean that the working condition fringe exclusion applies to employee tuition reductions, "notwithstanding implication to the contrary in" what is now $\S 132(l)$ ).

Pitt Tax Review | ISSN 1932-1821 (print) 1932-1996 (online)

DOI 10.5195/taxreview.2017.68 | http://taxreview.law.pitt.edu 
research assistants) are not excludable as qualified tuition reductions under $\S 117(\mathrm{~d}){ }^{241}$ After concluding that the $\S 117$ (d) exclusion was not available, the IRS then turned to whether the graduate tuition reductions were excludable under any part of $\S 132 .{ }^{242}$ Citing what is now $\S 132(l)$, the IRS first noted that, in general, $\S 132$ exclusions do not "apply[] to fringe benefits of a type for which the tax treatment is expressly provided elsewhere in the Code." ${ }^{243}$ But next, citing Regulation section 1.132-1(f)(1), the IRS recognized that

[t] he exception to this general rule is that if the amounts paid by the employer are for education relating to the employee's trade or business of being an employee of the employer so that, if the employee paid for the education, the amount paid could be deducted under section 162, the costs of the education may be eligible for exclusion as a working condition fringe under section 132(a)(3). ${ }^{244}$

Accordingly, the IRS determined that the graduate tuition reductions in question were "not excludable from gross income as a no-additional-cost service... [or as] qualified employee discounts." 45 At the same time, however, the IRS also indicated that, if they "relate[d] to the employee's trade or business as an employee of" the university, the "graduate tuition benefits $[$ could $]$ qualify as a working condition fringe." 246

${ }^{241}$ I.R.S. Priv. Ltr. Rul. 90-40-045 (July 10, 1990); see supra text accompanying notes 30-45.

${ }^{242}$ I.R.S. Priv. Ltr. Rul. 90-40-045 (July 10, 1990).

${ }^{243} I d$. (citing § 132(j) of the 1990 version of the Code).

${ }^{244}$ Id. (citing Treas. Reg. § 1.132-1(f)(1)) (emphasis added).

${ }^{245} \mathrm{Id}$.

${ }^{246} I d$. (citing Regulation section $1.132-5(\mathrm{a})(2)$ for the proposition that, to qualify as a working condition fringe, "it is not sufficient that the tuition, if paid by the employee, would be deductible as a trade or business expense," but that, in addition, "[t]he tuition benefits must relate to the employee's" work for the particular employer providing the benefits). In the letter ruling, the IRS ultimately declined to rule - one way or the other- on whether the graduate tuition reductions in question were in fact working condition fringes. Id. Presumably, the IRS was unable to make a blanket determination as to whether the graduate tuition reductions constituted working condition fringes because the highly fact-specific nature of the Regulation section 1.162-5 test would make it necessary to analyze the facts and circumstances of each particular tuition reduction to each particular employee on a case-by-case basis. See, e.g., Cheney, supra note 95, at 514-15 (discussing fact-specific nature of determinations under Regulation section 1.162-5). Nonetheless, the fact that the IRS left the question open indicates that - at the time of the ruling, at least - the IRS concluded that graduate tuition reductions are excludable as working condition fringes when the education in question meets the requirements of Regulation section 1.162-5. In the authors' view, that conclusion was correct.

Pitt Tax Review | ISSN 1932-1821 (print) 1932-1996 (online) DOI 10.5195/taxreview.2017.68 | http://taxreview.law.pitt.edu 


\section{8 |Pittsburgh Tax Review | Vol. 152017}

B. IRS Guidance States that the § 132(a)(3) Exclusion Does Not Apply to a Graduate Tuition Reduction-Unless the \& 127 Exclusion Also Applies to Such Tuition Reduction

Unfortunately, the IRS reversed its position and no longer adheres to the interpretation of $\S 132(l)$ set forth above. The IRS's current policy on the matter is elucidated in two pieces of guidance- one from $2002^{247}$ and another from $2010 .{ }^{248}$ In the 2002 guidance, the IRS concludes that $\S 132(l)$ and the regulations thereunder prevent the working condition fringe exclusion from ever applying to a graduate tuition reduction for an employee of an educational organization because the tax treatment of such tuition reductions is provided for in $\S 117(\mathrm{~d}){ }^{249}$ In the 2010 guidance, the IRS finds one exception: If the first $\$ 5,250$ of a graduate tuition reduction is excludable under $\S 127$ and if such tuition reduction meets $\S 132(d)$ 's definition of a "working condition fringe," then any reduction amount in excess of $\$ 5,250$ is excludable under $\S 132(\mathrm{a})(3) .{ }^{250}$

\section{The 2002 IRS Field Service Advice}

In a 2002 Field Service Advice, the IRS's Office of Chief Counsel gave its area counsel technical advice concerning the case of a university that (1) provided its employees with tuition reductions for graduate studies and (2) sought to characterize those benefits as excludable working condition fringes. ${ }^{251}$ The IRS began its analysis by observing that " $[t]$ he rules for tuition reduction arrangements are generally provided in Code $\S 117(\mathrm{~d}) .{ }^{, 252}$ It then noted how $\S 132(l)$ generally prevents $\S 132$ from "apply[ing] to any fringe benefits of a type[,] the tax treatment of which is expressly provided for in any other" Code section. ${ }^{253}$ In applying $\S 132(l)$ specifically to graduate tuition reductions, the IRS focused on the penultimate sentence in Regulation

\footnotetext{
${ }^{247}$ See I.R.S. Field Serv. Adv. 2002-31-016 (Mar. 13, 2002).

${ }^{248}$ See I.R.S. Non-Docketed Serv. Adv. Review 2010-39-01F (July 27, 2010).

${ }^{249}$ I.R.S. Field Serv. Adv. 2002-31-016 (Mar. 13, 2002).

${ }^{250}$ I.R.S. Non-Docketed Serv. Adv. Review 2010-39-01F (July 27, 2010).

${ }^{251}$ I.R.S. Field Serv. Adv. 2002-31-016 (Mar. 13, 2002).

${ }^{252} \mathrm{Id}$.

${ }^{253} \mathrm{Id}$.
}

Pitt Tax Review | ISSN 1932-1821 (print) 1932-1996 (online) DOI 10.5195/taxreview.2017.68 | http://taxreview.law.pitt.edu 
section 1.132-1(f)(1): “[B]ecause section 117(d) applies to tuition reductions, the exclusions under section 132 do not apply to free or discounted tuition provided to an employee by an organization operated by the employer, whether the tuition is for study at or below the graduate level." 254 Based largely on this language in the regulation, ${ }^{255}$ the IRS determined that "[t]uition reduction is the type of benefit provided for under Code $\S 117$; thus, Code $\S 132(l)$ precludes application of $\S 132$ to exclude tuition reduction amounts from gross income." 256

To arrive at that determination, the IRS had to explain away the last sentence of Regulation section 1.132-1(f)(1). As previously discussed, that sentence provides as follows:

Of course, if the amounts paid by the employer are for education relating to the employee's trade or business of being an employee of the employer so that, if the employee paid for the education, the amount paid could be deducted under section 162 , the costs of the education may be eligible for exclusion as a working condition fringe. ${ }^{257}$

In its 1990 private letter ruling, as noted above, the IRS read this language as an exception to $\S 132(l)$ 's general rule in the case of tuition reductions that qualify as working condition fringes. ${ }^{258}$ Nonetheless, in its 2002 Field Service Advice, the IRS essentially wrote that exception out of the regulation

${ }^{254}$ Id. (quoting Treas. Reg. § 1.132-1(f)(1) ( as amended in 1993)) (emphasis removed).

${ }^{255}$ For its threshold finding that $\S 117(\mathrm{~d})$ governs the treatment of graduate tuition reductions provided to educational organization employees - because $\S 117$ (d) deals with tuition reductions for educational organization employees generally - the IRS also relied on an above-mentioned passage from $\S 132$ 's legislative history indicating that "[a] benefit is not excludable under . . . section $132 \ldots$. . if another section of the Internal Revenue Code provides rules for the tax treatment of the general type of benefit." H.R. REP. No. 98-432, pt. 2, at 1608 (1984), quoted in I.R.S. Field Serv. Adv. 2002-31-016 (Mar. 13, 2002) (alteration in original); see also supra note 223 (discussing indications in Regulation section 1.132$1(\mathrm{f})(1)$ and above-quoted legislative history that $\S 117$ (d) provides for tax treatment of tuition reductions, for $§ 132(l)$ purposes).

${ }^{256}$ I.R.S. Field Serv. Adv. 2002-31-016 (Mar. 13, 2002). The IRS did allow for one theoretical exception: A tuition reduction could nevertheless be excluded under $\S 132(\mathrm{a})(4)$ if it were a de minimis fringe benefit under §132(e). See id.; see also I.R.C. § 132(l) ("This section (other than subsections (e) and $(\mathrm{g})$ ) shall not apply to any fringe benefits of a type the tax treatment of which is expressly provided for in any other section of this chapter.") (emphasis added).

${ }^{257}$ I.R.S. Field Serv. Adv. 2002-31-016 (Mar. 13, 2002) (quoting Treas. Reg. § 1.132-1(f)(1)) (alteration in original).

${ }^{258}$ See supra text accompanying notes $243-46$.

Pitt Tax Review | ISSN 1932-1821 (print) 1932-1996 (online) DOI 10.5195/taxreview.2017.68 | http://taxreview.law.pitt.edu 
by focusing on the word "paid" in the phrase "amounts paid by the employer." In arguing that the last sentence of Regulation section 1.1321(f)(1) does not apply to graduate tuition reductions, the IRS proffered that "the regulations seem to clearly distinguish between tuition reduction[s] under Code $\S 117$ and amounts paid by an employer for an employee's education under Code $\S 127 . " 259$

The IRS also argued that applying $\S 132(l)$ to deny the exclusion of a tuition reduction as a working condition fringe is consistent with the legislative history of $\S 132(\mathrm{j})(8)$. To that end, the IRS quoted the following passage from the House Report for the Omnibus Budget Reconciliation Act of 1989, which added $\S 132(\mathrm{j})(8)$ to the Code:

The provision $[\S 132(\mathrm{j})(8)]$ clarifies that, to the extent employer-provided educational assistance is not excludable under section 127 because it exceeds the maximum dollar limitation or because of the limitation on graduate-level courses, it may be excludable from income as a working condition fringe benefit (132(d)), provided the requirements of that section are otherwise satisfied (e.g., the education is job-related as defined under section 162). Educational assistance may not be excluded under any other provision of section $132 .^{260}$

As the IRS noted, the House Report makes clear that Congress "found it necessary to amend Code $\S 132 \ldots$ to provide that educational assistance that is not excludable under Code $\$ 127$ may be excludable under Code $\S 132 . " 261$ By the same token, however, the IRS contended that "Congress'

${ }^{259}$ I.R.S. Field Serv. Adv. 2002-31-016 (Mar. 13, 2002). The IRS attempted to reconcile its 2002 reading of the last sentence of Regulation section 1.132-1(f)(1) with its 1990 private letter ruling. It suggested that, when discussing graduate tuition benefits that could be excludable as working condition fringes, the 1990 letter ruling "appear[ed] to refer only to [§] 127 benefits." See id. However, in the 1990 letter ruling itself, the IRS did not actually state that the availability of the $\S 132(a)(3)$ exclusion was contingent on the applicability of $\S 127$. Rather, in that ruling, the IRS expressly acknowledged that the availability of the $\S 132(a)(3)$ exclusion for graduate tuition reductions that are working condition fringes is an "exception to [the] general rule" under § 132(l). I.R.S. Priv. Ltr. Rul. 90-40-045 (July 10, 1990); see also supra notes $241-46$. It is thus difficult to view the IRS's 2002 interpretation of $\S 132(l)$ and Regulation section 1.132-1(f)(1) as anything other than a complete reversal of its 1990 position.

${ }^{260}$ H.R. REP. No. 101-247, at 1172 (1989), quoted in I.R.S. Field Serv. Adv. 2002-31-016 (Mar. 13, 2002) (emphasis added); see also I.R.S. Non-Docketed Serv. Adv. Review 2010-39-01F (July 27, 2010) (quoting same).

${ }^{261}$ I.R.S. Field Serv. Adv. 2002-31-016 (Mar. 13, 2002) (emphasis added).

Pitt Tax Review | ISSN 1932-1821 (print) 1932-1996 (online)

DOI 10.5195/taxreview.2017.68 | http://taxreview.law.pitt.edu 
failure to include [a reference to] Code $\S 117$ in [§ 132(j)(8)] provides further support that tuition reductions are not excludable under Code $\S 132(d)$." ${ }^{262}$

Based on the foregoing, the IRS concluded that "[ $t]$ uition reduction provided by a university may not be excluded from an employee's gross income as a working condition fringe benefit."263

\section{The 2010 IRS Non-Docketed Service Advice Review}

In a 2010 Non-Docketed Service Advice Review, the IRS's Area Counsel considered " $[\mathrm{w}]$ hether graduate level tuition waivers provided by an educational institution to its employees qualify for exclusion from gross income or constitute a taxable fringe benefit." 264 The question related to the case of a particular university that had provided tuition reductions or waivers to its faculty and staff for graduate courses "to advance [the employees'] personal and professional development." ${ }^{265}$ The IRS began its analysis by stating that graduate tuition reductions for faculty and staff are not excludable as qualified tuition reductions under $\S 117(\mathrm{~d}) .{ }^{266}$ Next, it pointed out that, if the graduate tuition reductions or waivers were provided pursuant to an educational assistance program meeting the requirements of $\S 127(\mathrm{~b})$, the first $\$ 5,250$ of any such reduction or waiver for a given calendar year would be excludable under $\S 127(\mathrm{a}){ }^{267}$ Then, it turned to the question of whether

${ }^{262} I d$. The IRS further suggested that one "possible rationale for treating tuition reduction benefits differently is that there is little incentive to monitor whether graduate-level courses are job related when the courses result in no additional cost to the employer." Id.

${ }^{263} \mathrm{Id}$.

${ }^{264}$ I.R.S. Non-Docketed Serv. Adv. Review 2010-39-01F (July 27, 2010).

${ }^{265}$ Id. Under the university's Graduate and Post Graduate Tuition Benefits Program, the university's "[f]aculty, regular, full-time staff and limited service employees" were entitled to a $50 \%$ tuition reduction for university graduate courses after one year of full-time employment and a $100 \%$ tuition waiver for university graduate courses after two years of full-time employment. Id. In either case, the recipient employee was required to reimburse the university for the amount of the tuition reduction or waiver if he or she left the university's employ "within one year of completion of the graduate coursework." Id.

${ }^{266}$ See I.R.S. Non-Docketed Serv. Adv. Review 2010-39-01F (July 27, 2010).

${ }^{267}$ See id. The IRS did not expressly find whether the university provided the benefits in question under a $\S 127 \mathrm{plan}$. Instead, the 2010 guidance purports to set forth how the relevant exclusion provisions would apply, "[a]ssuming the tuition waiver program at [the university] meets the requirements of an educational assistance program" under § 127(b). Id.

Pitt Tax Review | ISSN 1932-1821 (print) 1932-1996 (online) DOI 10.5195/taxreview.2017.68 | http://taxreview.law.pitt.edu 


\section{2 |Pittsburgh Tax Review | Vol. 152017}

the tuition reductions and waivers were excludable as working condition fringes under $\S 132(\mathrm{a})(3){ }^{268}$

The IRS reiterated its 2002 determination that "tuition reductions provided for graduate level education by an educational institution employer that do not qualify for exclusion under $\S 117(\mathrm{~d})$ cannot be excluded as a working condition fringe under $\S 132 . "{ }^{269}$ And, once again, the IRS sought to reconcile that determination with the last sentence of Regulation section $1.132-1(f)(1) .{ }^{270}$ This time, rather than arguing that the sentence never applies to a graduate tuition reduction, ${ }^{271}$ the IRS surmised that it does apply "in the specific case where the tuition reduction meets the requirements for exclusion under $\S 127 . " 272$ Accordingly, the IRS allowed that, "if the tuition reductions qualify as educational assistance benefits (including graduate level classes) that can be excluded under $\S 127$ up to the $\$ 5,250$ cap, then the excess amount over the $\$ 5,250$ cap could be excluded as a working condition fringe under $\S 132,{ }^{, 273}$ so long as those tuition reductions meet the definition of a working condition fringe.

The IRS contended that such a result would be consistent with Regulation section 1.132-1(f)(2), which provides as follows:

If another section of Chapter 1 of the Internal Revenue Code of 1986 provides an exclusion from gross income based on the cost of the benefit provided to the employee and such exclusion is a limited amount, section 132 and the regulations

\footnotetext{
${ }^{268}$ See id. Of course, the working condition fringe exclusion could have potentially applied only if the coursework in question was sufficiently employment-related to meet the requirements of Regulation section 1.162-5. See supra Part IV.B. The IRS did not expressly address whether the graduate courses for which the tuition reductions or waivers were provided would meet Regulation section 1.162-5's standards, but the discussion in the 2010 guidance appears to assume that the benefits in question would meet the definition of a "working condition fringe" under $§ 132(d)$.

${ }^{269}$ I.R.S. Non-Docketed Serv. Adv. Review 2010-39-01F (July 27, 2010) (citing I.R.S. Field Serv. Adv. 2002-31-016 (Mar. 13, 2002)).

${ }^{270}$ For the sentence in question, see supra text accompanying note 257 (quoting last sentence of Treas. Reg. § 1.132-1(f)(1) (as amended in 1993)).

${ }^{271}$ See supra text accompanying note 259 (discussing such argument in the 2002 guidance).

${ }^{272}$ I.R.S. Non-Docketed Serv. Adv. Review 2010-39-01F (July 27, 2010).

${ }^{273} I d$.
}

Pitt Tax Review | ISSN 1932-1821 (print) 1932-1996 (online)

DOI 10.5195/taxreview.2017.68 | http://taxreview.law.pitt.edu 
thereunder may apply to the extent the cost of the benefit exceeds the statutory exclusion. ${ }^{274}$

In turn, according to the IRS, the interpretation set forth in Regulation section 1.132-1(f)(2) "is very similar to the exclusion allowed by I.R.C. $\S 132(\mathrm{j})(8) .{ }^{, 275}$ In other words, the IRS argued that $\S 132(\mathrm{j})(8)$ also permits a working condition fringe exclusion for graduate tuition reductions only if the first $\$ 5,250$ of the reduction is excludable under $\S 127$. As purported support for that argument, the IRS again quoted the same passage from $\S 132(\mathrm{j})(8)$ 's legislative history that it had recited in its 2002 guidance. ${ }^{276}$

On these bases, the IRS concluded that, "[w]hile $\S 132$ cannot be used to exclude graduate level tuition reductions that fail the requirements of $\S \S 117(\mathrm{~d})$ and 127, educational assistance (including graduate level classes) that would qualify for exclusion under $\S 127$ but for the statutory cap of $\$ 5,250$ can be excluded as a working condition fringe if the assistance meets the requirements of $\S \S 127$ and 132."277

\section{The IRS's Arguments and Conclusions in Its 2002 and 2010 Guidance} Are Erroneous and Are Based on Misreadings of the Applicable Code Provisions, Legislative History, and Treasury Regulations

In actuality, as explained above, $\S 132(l)$ does not prohibit the exclusion under $\S 132(\mathrm{a})(3)$ of a graduate tuition reduction that is also a working condition fringe - regardless of whether any portion of the tuition reduction is also excludable under $\S 127 .{ }^{278}$ The IRS's contrary position is simply wrong. In developing that position in its 2002 and 2010 guidance, the IRS made some serious interpretive errors. It arrived at its misconstruction of $\S 132(l)$ principally by misreading the Treasury regulations that interpret the

${ }^{274}$ Treas. Reg. § 1.132-1(f)(2), quoted in I.R.S. Non-Docketed Serv. Adv. Review 2010-39-01F (July 27, 2010).

${ }^{275}$ I.R.S. Non-Docketed Serv. Adv. Review 2010-39-01F (July 27, 2010).

${ }^{276}$ See id. (quoting H.R. REP. NO. 101-247, at 1172 (1989)). For the passage in question, see supra text accompanying note 260 .

${ }^{277}$ I.R.S. Non-Docketed Serv. Adv. Review 2010-39-01F (July 27, 2010).

${ }^{278}$ See supra Part V.A.

Pitt Tax Review | ISSN 1932-1821 (print) 1932-1996 (online) DOI 10.5195/taxreview.2017.68 | http://taxreview.law.pitt.edu 
provision. And in an effort to find support for that misconstruction in $\S 132(\mathrm{j})(8)$, it misapprehended $\S 132(\mathrm{j})(8)$ 's legislative history.

Most striking, perhaps, is how badly the IRS misreads Regulation section 1.132-1(f)(1). The last sentence thereof confirms that $\S 132(l)$ does not block $\S 132(\mathrm{a})(3)$ from applying to a graduate tuition reduction that is a working condition fringe. ${ }^{279}$ Yet, in its 2002 guidance, the IRS simply dismissed the sentence on the theory it applies only to "amounts paid by an employer for an employee's education under Code $\S 127 . " 280$ In short, that is a complete distortion of the regulation's language.

First, there is no support for the IRS's inference - in its 2002 guidancethat Regulation section 1.132-1(f)(1)'s reference to "amounts paid by the employer" is a reference to amounts that an employer pays to a third-party education provider for an employee's education. Instead, it is plain from the context that the reference is to amounts that the employer pays to its employee in the form of an educational benefit. Fringe benefits are a form of compensation for services. ${ }^{281}$ Thus, when an employer provides a fringe benefit - including an educational benefit - to an employee, it is compensating or paying that employee. Indeed, both before and after its 2002 guidance, the IRS itself has referred to graduate tuition reductions as payments to an employee. ${ }^{282}$ The reference to "the amounts paid by the employer" is in the last sentence of Regulation section 1.132-1(f)(1), which immediately follows a sentence discussing "free or discounted tuition provided to an employee by ... the employer." 283 Unless "the amounts paid by the employer" being referred to in the last sentence were the payments of "free or discounted tuition" referred to in the immediately preceding sentence, the latter sentence would be a complete non sequitur. As a result,

\footnotetext{
${ }^{279}$ See supra notes 239-40 (discussing the meaning of Treas. Reg. § 1.132-1(f)(1)).

${ }^{280}$ I.R.S. Field Serv. Adv. 2002-31-016 (Mar. 13, 2002); see also supra text accompanying notes $257-59$.

${ }^{281}$ See supra note 148 and accompanying text.

${ }^{282}$ For example, in its 2010 guidance, the IRS discussed a previous private letter ruling in which it "stated that a tuition reduction for graduate-level courses paid by a university to faculty by reason of the employer-employee relationship was not a 'qualified' tuition reduction ...." I.R.S. Non-Docketed Serv. Adv. Review 2010-39-01F (July 27, 2010) (emphasis added) (citing I.R.S. Priv. Ltr. Rul. 96-16-014 (Jan. 16, 1996)).

${ }^{283}$ Treas. Reg. § 1.132-1(f)(1).
}

Pitt Tax Review | ISSN 1932-1821 (print) 1932-1996 (online) DOI 10.5195/taxreview.2017.68 | http://taxreview.law.pitt.edu 
the IRS's interpretation in the 2002 guidance would render the last sentence of Regulation section 1.132-1(f)(1) entirely superfluous. For that reason alone, the interpretation should be rejected. ${ }^{284}$

Second, the IRS's 2002 argument that Regulation section 1.132-1(f)(1) distinguishes between tuition reductions, on one hand, and amounts paid by an employer to third-parties under $\S 127$, on the other, is inconsistent with $\S 127$ itself. As discussed above, subject to the annual \$5,250 cap and the requirements of $\S 127(\mathrm{~b}), \S 127(\mathrm{a})$ excludes both (1) amounts that an employer pays to third-party providers for an employee's education and (2) the value of educational courses that the employer itself provides to an employee. ${ }^{285}$ Therefore, even setting aside that Regulation section 1.132$1(\mathrm{f})(1)$ does not actually mention $\S 127$, an appeal to the latter provision cannot support the IRS's contention that only tuition paid by an employer to a separate education provider (and not tuition discounts for an employer's own courses) can qualify for the working condition fringe exclusion. ${ }^{286}$

284 "A well-established canon of construction requires that courts give all language in a statute operative effect. .. This canon is fully transferable to the construction of regulations. Thus, a court should interpret a regulation so that, "if it can be prevented, no clause, sentence, or word shall be superfluous, void, or insignificant." Morales v. Sociedad Espanola de Auxilio Mutuo y Beneficencia, 524 F.3d 54, 59 (1st Cir. 2008) (quoting TRW Inc. v. Andrews, 534 U.S. 19, 31 (2001)), cert. denied, 555 U.S. 1097 (2009).

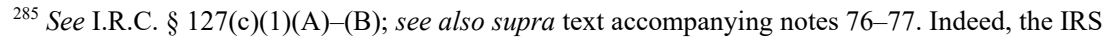
itself has acknowledged that the $\S 127$ exclusion encompasses education provided directly by an employer, in its 2002 guidance. See I.R.S. Non-Docketed Serv. Adv. Review 2010-39-01F (July 27, 2010) ("In addition, I.R.C. $\S 127$ 's definition of educational assistance includes courses provided directly by the employer, as an educational institution would do in the case of tuition reduction or waiver.").

${ }^{286}$ Equally unpersuasive is the IRS's observation, in its 2002 guidance, that "another possible rationale for treating tuition reduction benefits differently is that there is little incentive to monitor whether graduate-level courses are job related when the courses result in no additional cost to the employer." I.R.S. Field Serv. Adv. 2002-31-016 (Mar. 13, 2002); see supra note 262. Not only does the IRS fail to offer any textual support for that hypothesis in the Code, any legislative history, or the Treasury regulations; the hypothesis is factually incorrect. As discussed above, an educational institution-like any other employer-is required to report an employee's includible income on a Form W-2 and is required to pay employment taxes based on that income. See supra notes 8-9 and accompanying text. If an educational institution underreports employee income or underpays its employment taxes because it has incorrectly identified includible employee income as excludable, the institution will not only be subject to potential adjustments that will increase its employment taxes due (to correct any deficiency), but will also be subject to potential penalties. See supra note 12 and text accompanying notes 11-13 (discussing IRS study of colleges and universities that underreported taxable employee wages and underpaid employment taxes, and noting adjustments and penalties imposed on such schools). The prospect of such adjustments and

Pitt Tax Review | ISSN 1932-1821 (print) 1932-1996 (online) DOI 10.5195/taxreview.2017.68 | http://taxreview.law.pitt.edu 
The IRS's revised argument in its 2010 guidance - that the last sentence of Regulation section 1.132-1(f)(1) applies to a graduate tuition reduction only "in the specific case where the tuition reduction meets the requirements for exclusion under $\S 127^{, 287}$ - is similarly unavailing. The IRS argued that Regulation section 1.132-1(f)(2) ${ }^{288}$ supports such a reading of Regulation section 1.132-1(f)(1), but Regulation section 1.132-1(f)(2) does not do nearly as much work as the IRS contends. True, Regulation section 1.132-1(f)(2) indicates that the various prongs of $\S 132$ (a) can exclude benefit amounts in excess of what may be covered by other applicable exclusions. And, in so doing, Regulation section 1.132-1(f)(2) removes any concern as to whether $\S 127$ sets a limit (of $\$ 5,250$ ) on the excludable portion of a covered educational benefit that is also a working condition fringe. However, nothing in Regulation section 1.132-1(f)(2) states - or even suggests - that § 132(a)'s exclusions apply only when some other, limited exclusion (such as $\S 127$ ) also applies to the same benefit. Thus, Regulation section 1.132-1(f)(2) does nothing to support the IRS's position.

Nor is the IRS's argument bolstered by its miscomprehension of $\S 132(\mathrm{j})(8)$ 's legislative history. As noted above, the House Report on the legislation that enacted $\S 132(\mathrm{j})(8)$ indicates that Congress added the provision to the Code because of a need to clarify that employer-provided education benefits that constitute working condition fringes are excludable under $\S 132(\mathrm{a})(3)$, to the extent they cannot be excluded under $\S 127 .{ }^{289}$ Yet, in its 2002 guidance, the IRS deduced that, because Congress referred only to $\S 127$ - and not to $\S 117(\mathrm{~d})$ - when drafting $\S 132(\mathrm{j})(8)$, Congress must not have intended the working condition fringe exclusion to apply to graduate tuition reductions that are not excludable under $\S 117(\mathrm{~d}) .{ }^{290}$ Simply put, that deduction fails.

penalties gives universities significant incentive not to misidentify non-job-related educational benefits as excludable working condition fringes.

${ }^{287}$ I.R.S. Non-Docketed Serv. Adv. Review 2010-39-01F (July 27, 2010); see also supra text accompanying note 272 .

${ }^{288}$ See supra text accompanying note 274 (quoting Treas. Reg. § 1.132-1(f)(2)).

${ }^{289}$ See supra text accompanying notes $260-61$.

${ }^{290}$ See supra text accompanying note 262 (quoting I.R.S. Field Serv. Adv. 2002-31-016 (Mar. 13, 2002)).

Pitt Tax Review | ISSN 1932-1821 (print) 1932-1996 (online)

DOI 10.5195/taxreview.2017.68 | http://taxreview.law.pitt.edu 
Any educational benefit that is not provided under a $\S 127$ plan is, of course, not excludable under $\S 127$. Tuition reductions are thus but a subset of the educational benefits potentially within that category. Accordingly, there would have been no need for Congress to include any separate mention of $\S 117$ when drafting $\S 132(\mathrm{j})(8)$. The reference in $\S 132(\mathrm{j})(8)$ to benefits "which are not excludable from gross income under section 127",291 already encompasses tuition reductions that are not excludable under $\S 127$ or $\S 117(\mathrm{~d})$. Section 132(j)(8) provides that any employer-provided educational benefit that is not excludable under $\S 127$ is nevertheless excludable under $\S 132(a)(3)$ if it is a working condition fringe. ${ }^{292}$ Notwithstanding the IRS's mischaracterization of the underlying legislative intent, this includes any graduate tuition reduction provided by a university to its employee that cannot be excluded under $\S 127$, if the tuition reduction is a working condition fringe.

In its 2010 guidance, the IRS engaged in further misreading of the same legislative history to conclude - again, mistakenly - that $\S 132(\mathrm{j})(8)$ permits a working condition fringe exclusion for a graduate tuition reduction only if the first $\$ 5,250$ of the reduction is excludable under $\S 127 .{ }^{293}$ In fact, however, the above-quoted House Report ${ }^{294}$ supports exactly the opposite conclusion.

At the time of the 2010 guidance, $\S 127$ covered graduate, as well as undergraduate, educational assistance. But when $\S 132(\mathrm{j})(8)$ was introduced in $1989, \S 127$ did not apply to graduate education benefits. ${ }^{295}$ The House Report indicates that, in 1989, the working condition fringe exclusion would be available for educational benefits to which $\S 127$ did not apply-either because the amount of the benefit was greater than $\$ 5,250$ or because the

${ }^{291}$ I.R.C. $\S 132(\mathrm{j})(8)$.

${ }^{292}$ For further discussion of the scope of $\S 132(\mathrm{j})(8)$, see supra text accompanying notes 153-54.

${ }^{293}$ See I.R.S. Non-Docketed Serv. Adv. Review 2010-39-01F (July 27, 2010) (quoting H.R. REP. No. 101-247, at $1172(1989))$.

${ }^{294}$ For the relevant passage from H.R. REP. No. 101-247, at 1172 (1989), see supra text accompanying note 260 .

${ }^{295}$ See supra note 81 (discussing years in which $\S 127$ did or did not cover graduate education).

Pitt Tax Review | ISSN 1932-1821 (print) 1932-1996 (online) DOI 10.5195/taxreview.2017.68 | http://taxreview.law.pitt.edu 
benefit was for graduate education. ${ }^{296}$ In other words, according to the House Report, not only does $\S 132(j)(8)$ permit a working condition fringe exclusion for educational assistance in excess of $\S 127$ 's $\$ 5,250$ cap; it permits a working condition fringe exclusion for educational benefits that do not qualify under $\$ 127$ at all. Far from corroborating the IRS's position-that the working condition fringe exclusion for graduate tuition reductions is contingent on $\S 127$ eligibility - the legislative history of $\S 132(j)(8)$ shows just the reverse.

D. Taxpayers Have a Strong Basis on Which to Argue that Graduate Tuition Reductions Are Excludable as Working Condition FringesRegardless of Whether $\S 127$ Also Applies

So, where does this leave universities that provide, and faculty members who receive, graduate tuition reductions?

If the university provides the graduate tuition reduction pursuant to an educational assistance program that meets all of $\S 127$ 's requirements, the answer is simple: The first $\$ 5,250$ of reduction awarded in any calendar year is excludable from the faculty member's gross income (for the related taxable year) under $\S 127$. And, if the graduate tuition reduction meets $\S 132(\mathrm{~d})$ 's definition of a "working condition fringe," then the IRS will treat any portion of the reduction in excess of $\$ 5,250$ as excludable under $\S 132(a)(3) .{ }^{297}$

But what if no portion of the graduate tuition reduction is excludable under $\S 127$ - for example, because the university does not have a $\S 127$ educational assistance program or because the school's purported $\S 127$ plan is discriminatory in favor of highly compensated employees? Current IRS policy is to treat a graduate tuition reduction in such a case as includible in the recipient faculty member's gross income. The IRS will not consider the

${ }^{296}$ According to the House Report, § 132(j)(8) "clarifies that, to the extent employer-provided educational assistance is not excludable under section 127 because it exceeds the maximum dollar limitation or because of the limitation on graduate-level courses, it may be excludable from income as a working condition fringe benefit.” H.R. REP. NO. 101-247, at 1172 (1989) (emphasis added).

${ }^{297}$ See I.R.S. Non-Docketed Serv. Adv. Review 2010-39-01F (July 27, 2010).

Pitt Tax Review | ISSN 1932-1821 (print) 1932-1996 (online) DOI 10.5195/taxreview.2017.68 | http://taxreview.law.pitt.edu 
tuition reduction to be excludable under $\S 132(\mathrm{a})(3)$ - even if the benefit would otherwise meet the "working condition fringe" definition. ${ }^{298}$

The complexity of the applicable rules - and the IRS's convoluted analysis of them - has led universities to adopt differing policies of their own toward faculty graduate tuition reductions, for purposes of Form W-2 reporting and employment tax payments. Some schools' policies simply reflect the IRS's most recent administrative pronouncements on the subject. $^{299}$ Other schools, however, appear to follow contrary legal interpretations. ${ }^{300}$ If nothing else, these differences in approach highlight an ongoing confusion on the topic that is to the detriment of educational institutions and their faculties, alike. The authors posit that much of the confusion stems from the discrepancy between the applicable law, on one hand, and the IRS's specious interpretations thereof, on the other.

The IRS's most recent statements notwithstanding, any graduate tuition reduction that meets the definition of a working condition fringe should be excludable as a working condition fringe. As the foregoing discussion ${ }^{301}$

${ }^{298}$ See id.; I.R.S. Field Serv. Adv. 2002-31-016 (Mar. 13, 2002).

${ }^{299}$ For example, in a document prepared by its internal audit services department, Utah State University takes the position that $\$ 132$ 's working condition fringe exclusion cannot apply to an employee graduate tuition reduction unless $§ 127$ is also applicable. See Janna Hawkins, Internal Audit Servs., Utah St U., Employee/Dependent Scholarship and Tuition Reduction Taxability Decision Tree n.(A), https://www.usu.edu/internal-audit-services/pdfs/Educational\%20Assistance\%20Taxability\%20

Decision\%20Tree.pdf (last visited Jan. 3, 2018) (citing I.R.S. Non-Docketed Serv. Adv. Review 201039-01F (July 27, 2010); I.R.S. Field Serv. Adv. 2002-31-016 (Mar. 13, 2002)).

300 For example, a number of universities have adopted $\S 127$ plans that cover only tuition reductions for non-job-related graduate courses, apparently because they believe that employee tuition reductions for job-related graduate courses are always excludable as working condition fringes. In a presumable reference to $\S 132$ (a)(3)'s working condition fringe exclusion (which applies only to benefits whose cost would qualify as deductible under $\S 162$, if paid for by the employee), such schools explain that job-related graduate courses are not covered under their $\S 127$ plans because "[j]ob-related courses are already exempt from taxation under IRC $\$ 162$." See, e.g., Miss. ST. U., InTERNAL REVENUE CODE (IRC) $\S 127$ PLAN, at 2, www.hrm.msstate.edu/forms/downloadfile.php?id=1489 (last visited May 21, 2017); UnIV. OF CAL. POLICY T-182-77, TAXES: TAXATION OF SCHOLARSHIP AND FELlOWSHIP GRANTS AND EDUCATIONAL ASSistANCE, at 43 (July 31, 2013), http://afs.ucdavis.edu/our_services/tax-repcomp/documents-nubn/policies-nubn/University\%20of\%20California\%20Policy\%20T-182-

77\%20Taxes \%20Taxation\%20of\%20Scholarship\%20and\%20Fellowship $\% 20$ Grants $\% 20$ and $\% 20$ Educ ational\%20Assistance\%20-\%20T-182-77\%20-\%2007-31-2013.pdf.

${ }^{301}$ See generally supra Parts V.A-C.

Pitt Tax Review | ISSN 1932-1821 (print) 1932-1996 (online) DOI 10.5195/taxreview.2017.68 | http://taxreview.law.pitt.edu 
demonstrates, there are ample grounds on which either a university ${ }^{302}$ or an individual faculty member ${ }^{303}$ could challenge the IRS's position and argue for the exclusion of a graduate tuition reduction as a working condition fringe - even when such a benefit does not qualify under $\S 127$. Section 132(j)(8) plainly states that an educational benefit that cannot be excluded under $\S 127$ is still excludable as a working condition fringe. As indicated by both its clear and unambiguous statutory language ${ }^{304}$ and its legislative history, ${ }^{305} \S 132(\mathrm{j})(8)$ not only permits the exclusion of benefit amounts in excess of $\S 127$ 's $\$ 5,250$ annual cap; it permits the working condition fringe exclusion in cases where $\S 127$ does not apply at all. Moreover, as reflected in the last sentence of Regulation section 1.132-1(f)(1), §132(l) never prohibits the exclusion of a fringe benefit as a working condition fringe, even when the benefit is of a type whose tax treatment is generally covered by a Code provision other than $\S 132 .{ }^{306}$ Thus - consistent with $\S 132(\mathrm{j})(8)^{307}$ there is an exception to the general rule of $\S 132(l)$ in the case of, for example, employer-provided tuition reductions that (1) generally may be governed under $\S 117(\mathrm{~d})$ but (2) are also working condition fringes. ${ }^{308}$ In short, if a

\footnotetext{
${ }^{302}$ As discussed above, a university is required to report employee wages on Form W-2 and to pay employment taxes based on the amounts of those wages. However, those wage amounts do not include income that is excludable. See supra notes 8-9 and accompanying text. If a university were to treat graduate tuition reductions as excludable from the recipient faculty members' gross income, the IRS might propose adjustments to the university's employment tax returns and even seek to impose underpayment or underreporting penalties. Cf. supra notes 11-13 and accompanying text (discussing employment tax examinations of sample universities that understated employees' includible income - in part due to exclusion of graduate tuition waivers - and resulting adjustments and penalties). In such a case, the university could challenge the IRS's proposed treatment of the tuition reductions.

${ }^{303}$ As discussed above, if a university reports an employee's wages to include an amount that is properly excludable, the employee can effectively exclude such amount by taking a deduction in such amount when figuring adjusted gross income. See supra note 14. If the IRS denies such deduction, the employee could challenge that denial.

${ }^{304}$ See supra notes $153-54$ and accompanying text.

${ }^{305}$ See supra text accompanying notes 293-96; see also supra text following note 296.

${ }^{306}$ See supra text accompanying notes 239-40.

${ }^{307}$ See supra note 238 and preceding text (discussing working condition fringe exception to $\S 132(l)$ and interplay between $\S 132(l)$ and $(\mathrm{j})(8)$ in the case of graduate tuition reductions that are working condition fringes).

${ }^{308}$ For an explanation of why such an exception to $\S 132(l)$ 's general rule is necessary and appropriate, see supra notes 233-38 and accompanying text. At one point, as noted above, even the IRS itself recognized that such an exception exists. See supra text accompanying notes 243-46.
}

Pitt Tax Review | ISSN 1932-1821 (print) 1932-1996 (online)

DOI 10.5195/taxreview.2017.68 | http://taxreview.law.pitt.edu 
university or an individual faculty member challenged the IRS's current position to the contrary, the relevant authorities would strongly support the taxpayer's argument.

If a taxpayer were to mount such a challenge, the court deciding the case would not accord any deference to the IRS's 2002 or 2010 guidance. Under $\S 6110(\mathrm{k})(3),{ }^{309}$ Chief Counsel advice (just like technical advice memoranda and private letter rulings ${ }^{310}$ ) "may not be used or cited in any precedential way and thus, a fortiori, may not be used to support, in any fashion, an argument that one interpretation of the Code is more authoritative than another." 311 Indeed, each of the two pieces of guidance contains an express statement - prominently displayed at the top of the document - that it may not be used as precedent in other cases. ${ }^{312}$ As a result, a court would not merely be prevented from viewing those pieces of guidance as dispositive, but would be prohibited from relying on that guidance at all. ${ }^{313}$ The IRS, in other words, would have no basis on which to argue that a court should defer

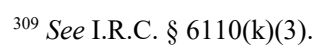

${ }^{310}$ See supra note 47.

${ }^{311}$ Vons Cos., Inc. v. United States, 51 Fed. Cl. 1, 12 (2001); see also Schlumberger Tech. Corp. v. United States, 55 Fed. Cl. 203, 212 (2003) (" $[\mathrm{I}] \mathrm{t}$ is clear that . . . technical advice memoranda 'may not be used or cited as precedent."') (quoting I.R.C. § 6110(k)(3)). As reflected in § 6110(k)(3)'s legislative history, the reason why such IRS determinations are not granted precedential value is - at least in partthat they are not subjected to adequate review (for purposes of establishing precedent) prior to issuance:

[A] private letter ruling, technical advice memorandum, or determination letter is not to be used as a precedent by the IRS or any person. If all publicly disclosed written determinations were to have precedential value, the IRS would be required to subject them to considerably greater review than is provided under present procedures. The committee believes that resulting delays in the issuance of determinations would mean that many taxpayers could not obtain timely guidance from the IRS and the rulings program would suffer accordingly.

S. ReP. No. 94-938, at 316 (1976), quoted in Vons Cos., 51 Fed. Cl. at 9.

${ }^{312}$ See I.R.S. Non-Docketed Serv. Adv. Review 2010-39-01F (July 27, 2010) (“This advice may not be used or cited as precedent in other cases."); I.R.S. Field Serv. Adv. 2002-31-016 (Mar. 13, 2002) ("In accordance with . . . $6110(\mathrm{k})(3)$, this Chief Counsel Advice should not be cited as precedent.").

${ }^{313}$ Section $6110(\mathrm{k})(3)$ does not "simply indicate[] that private letter rulings and technical advice memoranda are not "binding precedent." Vons Cos., 51 Fed. Cl. at $10 \mathrm{n}$.7. Instead, "the plain language of that section clearly precludes a court from giving such rulings and memoranda any precedential weight." Id.; see also id. at 11 (discussing United States v. Hill, 506 U.S. 546, 564 n.12 (1993), in which "the Supreme Court reversed a Federal Circuit decision that had found a [technical advice memorandum] 'instructive,' eschewing any reliance on the same memorandum by admonishing that 'the Code specifically provides that such memoranda may not be used or cited as precedent.'”).

Pitt Tax Review | ISSN 1932-1821 (print) 1932-1996 (online) DOI 10.5195/taxreview.2017.68 | http://taxreview.law.pitt.edu 
to the interpretations or conclusions in the 2002 and 2010 guidance. ${ }^{314}$ Instead, a court would accord those interpretations and conclusions no more weight than it would give to a litigating position that the IRS might advance in a court brief..$^{315}$ And, as with any other position argued by a litigant, a court will reject the position if it finds the argument to be unreasonable. ${ }^{316}$

${ }^{314}$ The IRS's 2002 and 2010 guidance are informal administrative interpretations of the Code that are prohibited by statute from being used as precedent. By virtue of both the type of pronouncements and the subject matter of the pronouncements in question, those pieces of guidance do not fall within the universe of IRS administrative determinations that command any deference. "The Supreme Court has firmly established that agency interpretations of their own regulations are entitled to substantial deference." Am. Express Co. v. United States, 262 F.3d 1376, 1382 (Fed. Cir. 2001) (citing Auer v. Robbins, 519 U.S. 452, 461-62 (1997), in which "the Supreme Court held that deference was required to be given to the Secretary of Labor's interpretation of the Department of Labor's own regulation in determining whether certain public-sector employees were exempted from mandatory overtime pay under the Fair Labor Standards Act"). Under this maxim, "[i]n the context of tax cases, the IRS's reasonable interpretations of its own regulations and procedures are entitled to particular deference." Id. at 1383 (citing United States v. Cleveland Indians Baseball Co., 532 U.S. 200, 220 (2001)). This means, for example, that the Court will respect an interpretation in an IRS Revenue Procedure of a Treasury regulation on the question of when an employer is required to pay employment taxes with respect to employees' back wages. See United States v. Cleveland Indians Baseball Co., 532 U.S. 200, 219-20 (2001). Similarly, a court will accord weight to the IRS's interpretation of its own Revenue Procedure concerning the proper taxable year in which an accrual-basis taxpayer must include income for future services. See Am. Express, 262 F.3d at 1382-83. However, while a court will defer to certain informal IRS rulings, such as Revenue Rulings or Revenue Procedures, when those pronouncements constitute interpretations of the IRS's own rules, a court may never grant such deference to private letter rulings or technical advice memoranda. See Schlumberger Tech. Corp., 55 Fed. Cl. at 212 n.5 ("Revenue Rulings . . . are entitled to some deference because these are the Internal Revenue Service's interpretation of its own regulations.... By comparison, private letter rulings and technical advice memorandum 'may not be used or cited as precedent."”) (quoting I.R.C. § 6110(k)(3)). Moreover, even a Revenue Ruling or Revenue Procedure - let alone a private letter ruling or technical advice memorandum - is not entitled to such deference when the pronouncement contains an interpretation of the Code. See Am. Express, 262 F.3d at 1382 (deference to IRS interpretation of its own Revenue Procedure was appropriate because court was "not dealing with an agency's interpretation of a statute and issues of Chevron deference"); see also Schlumberger Tech. Corp., 55 Fed. Cl. at 212 n.5 (noting that-in contrast to private letter rulings and technical advice memoranda, which are statutorily prohibited from ever being accorded any precedential weight - Revenue Rulings are sometimes entitled to some deference but "do not have the force of law ... because they have not been subject to notice and comment, and therefore are "beyond the Chevron pale"').

${ }^{315}$ See Vons Cos., 51 Fed. Cl. at 12 (noting that IRS “memoranda are entitled to no more weight or deference than any other informal agency interpretation, including a position taken on a brief"). $C f$. CSI Hydrostatic Testers, Inc. v. Comm'r, 103 T.C. 398, 409 n.10 (1994) (“[Section] 6110([k])(3) provides that private letter rulings may not be used or cited as precedent, and therefore ... the interpretation of a statute or a regulation provided by the [IRS] in a private letter ruling is entitled to no more deference than a litigating position before this Court."), aff'd, 62 F.3d 136 (5th Cir. 1995).

${ }^{316}$ Cf. True Oil Co. v. Comm'r, 170 F.3d 1294, 1302 (10th Cir. 1999) (noting, for example, that a court "will not defer to" an IRS interpretation of the Code in a private letter ruling, "if that interpretation

Pitt Tax Review | ISSN 1932-1821 (print) 1932-1996 (online)

DOI 10.5195/taxreview.2017.68 | http://taxreview.law.pitt.edu 
In the authors' view, a taxpayer could make a strong showing as to the unreasonableness of the IRS's administrative rulings in this area. As shown above, the IRS's conclusions in its 2002 and 2010 guidance were based on Code interpretations that are contrary to the plain meaning of the statutory language and the relevant legislative history, and on unreasonable interpretations and applications of Treasury regulations. ${ }^{317}$ In sum, based on all of the authorities discussed above, there is at least a reasonable basis ${ }^{318}$

conflicts with the plain language of the statute"-in which case such interpretation would obviously be unreasonable).

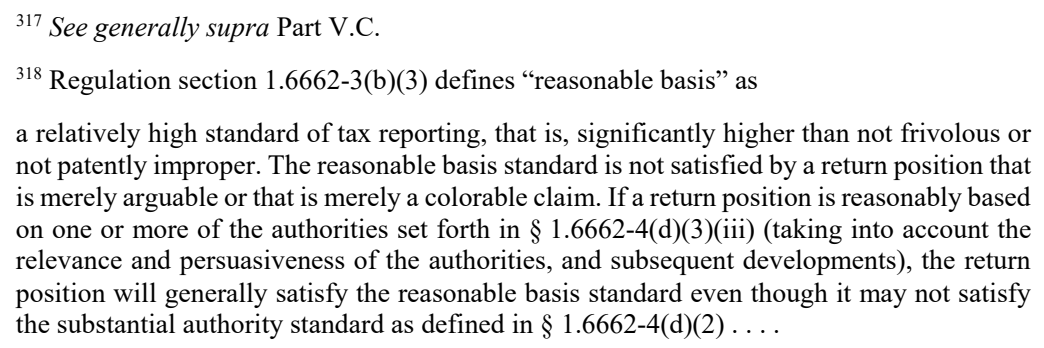
not patently improper. The reasonable basis standard is not satisfied by a return position that is merely arguable or that is merely a colorable claim. If a return position is reasonably based on one or more of the authorities set forth in $\S 1.6662-4$ (d)(3)(iii) (taking into account the relevance and persuasiveness of the authorities, and subsequent developments), the return position will generally satisfy the reasonable basis standard even though it may not satisfy the substantial authority standard as defined in $\S 1.6662-4(d)(2) \ldots$

Treas. Reg. $§ 1.6662-3(\mathrm{~b})(3)$ (as amended in 2003). In practice, the reasonable basis standard is generally interpreted as requiring that - based on a weighing of authorities that support a position, versus authorities that controvert the position - there be approximately a twenty percent likelihood that the position will be upheld on its merits (in court) if it is challenged. The "reasonable basis" defense is a potential defense against several of the accuracy-related underpayment penalties in $\S 6662$. A return position that has a reasonable basis is not subject to the negligence penalty under $\S 6662(\mathrm{~b})(1)$. Treas. Reg. $\S 1.6662-3(\mathrm{~b})(1)$. If a return position both has a reasonable basis and is adequately disclosed (usually on a Form 8275 or Form 8275-R, as appropriate), the position will not be subject to the disregard-of-rules-or-regulations penalty under $\S 6662(b)(1)$. Treas. Reg. $\S 1.6662-3(\mathrm{c})$. The combination of reasonable basis for, and adequate disclosure of, a return position is also a defense against the substantial understatement penalty under $\S 6662$ (b)(2). See I.R.C. $\S 6662(d)(2)(B)(i i)$.

Pitt Tax Review | ISSN 1932-1821 (print) 1932-1996 (online)

DOI 10.5195/taxreview.2017.68 | http://taxreview.law.pitt.edu 
and, almost as certainly, substantial authority ${ }^{319}$ - for taking the position ${ }^{320}$ that the IRS's most recent interpretations are wrong, and that a graduate tuition reduction within the "working condition fringe" definition of $\S 132(d)$ is always excludable under $\S 132(\mathrm{a})(3)$, regardless of whether $\S 127$ would also apply.

\section{CONCLUSION}

Both a university that provides, and a faculty member who receives, a graduate tuition reduction must navigate through a dizzying maze of interrelating Code provisions and Treasury regulations to determine whether the tuition reduction is includible in, or excludable from, the faculty member's gross income. Section 117(d)'s exclusion of "qualified tuition reductions" will not apply to a faculty graduate tuition reduction, but $\S 127$ (a) may provide an exclusion of the first $\$ 5,250$ of the reduction-if the university provides the benefit under an educational assistance program meeting all of $\S 127(\mathrm{~b})$ 's many requirements. The most valuable potential exclusion in this context would be the one under $\S 132$ (a)(3). If a faculty graduate tuition reduction were excludable as a working condition fringe, the entire reduction would be excluded from the recipient's gross income. Unfortunately, the IRS currently takes the position that the $\S 132(a)(3)$

\footnotetext{
${ }^{319}$ Regulation section 1.6662-4(d)(2) describes the "substantial authority" standard as

an objective standard involving an analysis of the law and application of the law to relevant facts. The substantial authority standard is less stringent than the more likely than not standard (the standard that is met when there is a greater than 50-percent likelihood of the position being upheld), but more stringent than the reasonable basis standard.... The possibility that a return will not be audited or, if audited, that an item will not be raised on audit, is not relevant in determining whether the substantial authority standard (or the reasonable basis standard) is satisfied.
}

Treas. Reg. §1.6662-4(d)(2) (as amended in 2003). In practice, the substantial authority standard is generally interpreted as requiring that - based on a weighing of authorities that support a position, versus authorities that controvert the position - there be approximately a $40 \%$ likelihood that the position will be upheld on its merits (in court) if it is challenged. Having substantial authority for a return position is a potential defense to the substantial understatement penalty under $\S 6662(b)(2)$. For purposes of determining whether a taxpayer's understatement of tax is large enough to trigger the substantial understatement penalty, one does not count any portion of the understatement attributable to "the tax treatment of any item by the taxpayer if there is or was substantial authority for such treatment." I.R.C. $\S 6662(\mathrm{~d})(2)(\mathrm{B})(\mathrm{i})$.

${ }^{320}$ See Kalafat, supra note 15, at 2022 (discussing role of reasonable basis and substantial authority defenses to $\S 6662$ penalties in taxpayers' decisions whether to deduct educational benefits, in light of confusion surrounding proper treatment of such benefits).

Pitt Tax Review | ISSN 1932-1821 (print) 1932-1996 (online)

DOI 10.5195/taxreview.2017.68 | http://taxreview.law.pitt.edu 
exclusion is available only if the $\S 127$ exclusion would also apply to the tuition reduction in question. This article argues that the IRS's position is plainly contrary to the applicable law and regulations. There are substantial grounds on which a taxpayer could challenge that position and argue for a $\S 132(a)(3)$ exclusion of a graduate faculty tuition reduction, even when $\S 127$ does not apply.

Pitt Tax Review | ISSN 1932-1821 (print) 1932-1996 (online) DOI 10.5195/taxreview.2017.68 | http://taxreview.law.pitt.edu 
